\title{
Review \\ Recent Advances in Endocrine Disrupting Compounds Degradation through Metal Oxide-Based Nanomaterials
}

\author{
Claudio Imparato ${ }^{1}$ (D) Aurelio Bifulco ${ }^{1}$ (D) , Brigida Silvestri ${ }^{1(D)}$ and Giuseppe Vitiello ${ }^{1,2, *(D)}$ \\ 1 Department of Chemical, Materials and Production Engineering, University of Naples Federico II, \\ 80125 Naples, NA, Italy; claudio.imparato@unina.it (C.I.); aurelio.bifulco@unina.it (A.B.); \\ brigida.silvestri@unina.it (B.S.) \\ 2 CSGI, Center for Colloid and Surface Science, Via della Lastruccia 3, 50019 Sesto Fiorentino, FI, Italy \\ * Correspondence: giuseppe.vitiello@unina.it; Tel.: +39-081-768-5975
}

check for updates

Citation: Imparato, C.; Bifulco, A.; Silvestri, B.; Vitiello, G. Recent Advances in Endocrine Disrupting Compounds Degradation through Metal Oxide-Based Nanomaterials. Catalysts 2022, 12, 289. https:/ / doi.org/10.3390/catal12030289

Academic Editor: Adam F. Lee

Received: 5 February 2022

Accepted: 1 March 2022

Published: 3 March 2022

Publisher's Note: MDPI stays neutral with regard to jurisdictional claims in published maps and institutional affiliations.

Copyright: (C) 2022 by the authors. Licensee MDPI, Basel, Switzerland. This article is an open access article distributed under the terms and conditions of the Creative Commons Attribution (CC BY) license (https:// creativecommons.org/licenses/by/ $4.0 /)$.

\begin{abstract}
Endocrine Disrupting Compounds (EDCs) comprise a class of natural or synthetic molecules and groups of substances which are considered as emerging contaminants due to their toxicity and danger for the ecosystems, including human health. Nowadays, the presence of EDCs in water and wastewater has become a global problem, which is challenging the scientific community to address the development and application of effective strategies for their removal from the environment. Particularly, catalytic and photocatalytic degradation processes employing nanostructured materials based on metal oxides, mainly acting through the generation of reactive oxygen species, are widely explored to eradicate EDCs from water. In this review, we report the recent advances described by the major publications in recent years and focused on the degradation processes of several classes of EDCs, such as plastic components and additives, agricultural chemicals, pharmaceuticals, and personal care products, which were realized by using novel metal oxide-based nanomaterials. A variety of doped, hybrid, composite and heterostructured semiconductors were reported, whose performances are influenced by their chemical, structural as well as morphological features. Along with photocatalysis, alternative heterogeneous advanced oxidation processes are in development, and their combination may be a promising way toward industrial scale application.
\end{abstract}

Keywords: endocrine disruptors; metal oxides; nanomaterials; nanostructured catalysts; photocatalysis; degradation

\section{Introduction}

The growing anthropogenic impact of an exacerbated consumption of products in recent years has induced a continuous discharge into the environment of wastes and new substances which are increasingly harmful to public, animal, and environmental health. Endocrine Disrupting Compounds (EDCs) are inserted in this group of contaminants of emerging concern as recalcitrant and persistent chemicals, which have been widely and increasingly detected in various water matrices, attracting a great attention due to their toxicity and danger for all ecosystems [1-3]. Indeed, EDCs are a large and heterogeneous group of natural or synthetic compounds that are progressively known for their adverse consequences on the endocrine system. They can act as substitutes for the hormones, which are an essential part of the suitable functioning of the human and animal organism, mimicking or inhibiting their effects, thus being able to alter their levels and affect the health of the endocrine system as well as of other systems linked to it $[4,5]$. Hormonal disturbances caused by EDCs may cause long-lasting and irreversible health problems. Indeed, growing evidence has demonstrated that these compounds contributed to the rapid increase of metabolic syndromes (i.e., insulin resistance, obesity, type 2 and type 1 diabetes, thyroid diseases) and may be associated with an increased incidence of breast cancer, abnormal growth patterns, reproductive abnormalities, and neurodevelopmental delays in children, as well as with changes in immune function [5]. 
For these reasons, the presence of EDCs in water and wastewater has become a global problem, drawing the attention of international agencies and governments, as well as of an increasing number of research devoted to the identification [2] and abatement/degradation of EDCs present in waters [6]. A great deal of attention has been directed towards the development and application of advanced oxidation processes (AOPs) to eradicate EDCs from various water sources with high efficiency, thus leading to an increase of clean water supply. Compared with conventional technologies, materials nanotechnology offers very flexible and efficient remediation options for water pollutants. Nanostructured materials exhibit a range of features, such as high reactivity, large surface area (surface-to-volume ratio), tunable porosity and surface properties, which make them valuable in fields like catalysis, sensing and biomedicine [7-11]. The growing design of novel nano-catalysts, nano-structured catalytic membranes, and/or nano-sorbents with enhanced efficiency for contaminants removal is a hopeful strategy to contribute solving the worldwide hazardous problem of EDCs water pollution [1,12-15].

In this context, an updated overview on the recently designed (photo)catalytic metaloxide nanomaterials with highest performances in the EDCs removal appears a useful tool for the scientific community to strategically direct the academic and technological research activities in this field. The proposed review is conceived for this purpose and reports the recent advances, as described by the major publications of the last four years (2018-2021), in the design and application of metal oxide-based nanomaterials in catalytic and photocatalytic degradation processes for the removal from wastewater of the most widespread EDCs belonging to different classes of formulations, such as components and additives of polymeric materials, agricultural chemicals, pharmaceuticals and personal care products.

\section{Endocrine Disrupting Compounds (EDCs)}

\subsection{Historical Definition and Regulatory Evolution}

The term "endocrine disruptor" was coined for the first time in 1991 at the Wingspread Conference Center. In 1993, Colborn, T. et al. published a paper [16] focusing on the disrupting role exerted by environmental chemicals on the development of the endocrine system, and on the permanent effects induced by a continuous exposure. In the subsequent years, great attention was addressed to the endocrine disruption by the scientific community [17-19], thus generating consensus statements regarding the hazard from endocrine disruptors, particularly in wildlife and in humans. In 1998, the United States Environmental Protection Agency (US EPA) proposed the first definition of Endocrine Disrupting Compounds (EDCs) as "exogenous agents that interfere with the production, release, transport, metabolism, binding, action, or elimination of the natural hormones in the body responsible for the maintenance of homeostasis and the regulation of developmental processes" [20,21]. In 2002, the World Health Organization (WHO) stated "an endocrine disruptor is an exogenous substance or mixture that alters function(s) of the endocrine system and consequently, causes adverse health effects in an intact organism, or its progeny, or (sub)populations" [20]. In 2013, the WHO and the United Nations Environment Programme released a comprehensive report on EDCs to date, calling for more research to fully understand the associations between EDCs and the risks to health of human and animal life. This work pointed to wide gaps in knowledge and called for more research to obtain a complete depiction of the health and environmental impacts of endocrine disruptors. On October 2020, the European Commission (EU) adopted the "EU Chemicals Strategy for Sustainability" as the first step towards a toxic-free environment under the European Green Deal [22]. This Chemicals Strategy proposes to establish endocrine disruptors as a hazard category in the Classification, Labelling and Packaging (CLP) Regulation. In particular, the Chemicals Strategy set out a vision to ensure that by 2030 a toxic-free environment should be achieved, where chemicals are produced and used in a way that maximizes their contribution to society, while minimizing harm to the planet and current and future generations. On these bases, a growing attention is addressed to reduce the harmful EDCs 
impact on the environment and public health, thus defining strategic approaches to realize their removal which is fundamental, together with the reduction of their use, to pursue an environmental sustainability.

\subsection{Main Natural and Synthetic EDCs}

From a chemical point of view, EDCs are natural or synthetic substances with different structural and functional features. Different lists of substances with confirmed or potential endocrine disrupting activity are available. For example, the European Chemical Agency (ECHA) reports an endocrine disruptor assessment list including the substances undergoing an evaluation under REACH (Registration, Evaluation, Authorization and Restriction of Chemicals) or Biocidal Products Regulations. The U.S. National Institute of Environmental Health Sciences (NIEHS) and US EPA currently conduct research on EDCs and strategies to identify them, in the framework of a National Toxicology Program. However, a widely accepted systematic method to identify EDCs hazards by integrating literature data is still lacking [23]. Therefore, it should be noted that these lists may differ according to the criteria used in their definition, and that they are constantly subject to changes and updates as new evidence is found about the effects of the chemicals concerned. In this review, the most recent sources and literature reports are taken as reference in the selection of compounds considered as certain or potential EDCs; however, it does not intend to provide a complete or definitive list of EDCs.

Natural molecules recognized as EDCs include phytoestrogens, which are plantderived hormones and are found in widely consumed food and animal products. These are less harmful than synthetic EDCs since they commonly have low affinity for estrogen receptors. At the same time, they exhibit low stability compared to many synthetic substances that are engineered to be stable. However, the potential health risks of phytoestrogens need to be considered, due to elevated levels in some foods and to that they can bind ERs with high affinity [24]. Specifically, daidzein and genistein (Figure 1) are the most abundant natural phytoestrogens detected in all foods. Using an in vitro bioassay, many of these had higher activation of estrogen beta-receptors than estrogen alpha-receptors.
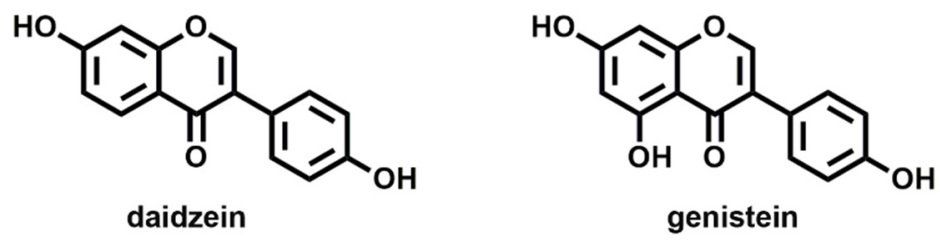

Figure 1. Molecular structures of the most common natural phytoestrogens: daidzein and genistein.

Synthetic EDCs are far more diverse, with several hundred identified and classified as persistent (exhibiting bioaccumulation) or non-persistent in the environment. These compounds are present in many commonly used household and industrial products. They include chemicals used as solvents or lubricants, plasticizers, pesticides [25], fungicides, and pharmaceutical agents, that are present in plastics, detergents, household chemicals and building products, fire retardants, food, medicines, personal care products, perfume, and cosmetics. Dichlorodiphenyltrichloroethane (DDT), polychlorinated biphenyls (PCBs), bisphenol A (BPA), polybrominated diphenyl ethers (PBDEs), perfluoroalkyl compounds, antibacterial triclosan (TCS) which binds with low affinity to both the androgen and estrogen receptors in vitro [26], polycyclic aromatic hydrocarbons (PAHs), and a variety of phthalates are the most detected in people [3,4]. Instead, 17 $\beta$-estradiol (E2) and ethynyl estradiol (EE2) are the most diffused synthetic hormones. A summary of the main groups of molecules with endocrine disrupting activity is reported in Table 1. 
Table 1. Summary of the most used EDCs impacting the immune response.

\begin{tabular}{|c|c|c|}
\hline Endocrine Disrupting Compounds & Main Sources & Description \\
\hline $\begin{array}{l}\text { Bisphenols } \\
\text { (e.g., BPA) }\end{array}$ & $\begin{array}{l}\text { Epoxy composites, polyester resins, } \\
\text { polycarbonate plastics, conserved food, } \\
\text { dental sealants }\end{array}$ & $\begin{array}{l}\text { Highly pervasive, } \\
\text { estrogen mimic }\end{array}$ \\
\hline $\begin{array}{l}\text { Phthalates } \\
\text { (e.g., dimethyl phthalate) }\end{array}$ & $\begin{array}{l}\text { Polyvinylchloride (PVC), } \\
\text { personal care products, } \\
\text { medical devices }\end{array}$ & $\begin{array}{l}\text { Effects on endocrine and } \\
\text { reproductive systems }\end{array}$ \\
\hline $\begin{array}{l}\text { Alkylphenols } \\
\text { (e.g., nonylphenol, octylphenol) }\end{array}$ & $\begin{array}{l}\text { Non-ionic surfactants, industrial } \\
\text { products, cosmetics }\end{array}$ & Lipophilic properties, estrogenic activity \\
\hline $\begin{array}{l}\text { Brominated flame retardants } \\
\text { (polybrominated diphenyl ethers) }\end{array}$ & $\begin{array}{l}\text { Household products, } \\
\text { industrial products }\end{array}$ & Carcinogenicity \\
\hline $\begin{array}{l}\text { Insecticides (e.g., DDT) } \\
\text { Herbicides (e.g., atrazine) } \\
\text { Fungicides (e.g., vinclozolin) }\end{array}$ & Agricultural and household uses & $\begin{array}{l}\text { Persistent agents, } \\
\text { estrogen mimic }\end{array}$ \\
\hline $\begin{array}{l}\text { Parabens } \\
\text { (e.g., methylparaben) }\end{array}$ & $\begin{array}{l}\text { Common preservatives, food, } \\
\text { cosmetics, pharmaceuticals }\end{array}$ & Estrogenic effect \\
\hline Antibacterial agents (e.g., triclosan) & Cosmetics, pharmaceuticals & Effects on reproductive hormons \\
\hline $\begin{array}{l}\text { Antibiotics (e.g., cyclines) } \\
\text { Anti-inflammatory drugs } \\
\text { (e.g., paracetamol, ibuprofen, diclofenac) }\end{array}$ & Pharmaceutical products & Effects on the level of estrogen hormones \\
\hline $\begin{array}{l}\text { Synthetic hormones } \\
\text { (e.g., 17ß-estradiol) }\end{array}$ & $\begin{array}{l}\text { Oral contraceptive pills, } \\
\text { wastewater contamination }\end{array}$ & Strong estrogenic behavior \\
\hline
\end{tabular}

\subsection{Main EDC Sources as Risks for Natural Ecosystems}

Although many countries and relevant international corporations have put restrictions on the use of many EDCs, the presence of a great amount in the air, soil, and aquatic environments (i.e., drinking water, industrial and urban wastewaters or underground water) is a critical ecological issue which can impact the reproductive performance of the natural ecosystems $[27,28]$. Nowadays, exposure to EDCs can happen through direct ingestion of contaminated food and water, inhalation of combusted contaminants, and direct contact with a variety of consumer products. Water contamination has been one of the major concerns regarding the overexposure of humans and animals to these compounds. EDCs can reach water bodies through the inadequate disposal of personal care products and medicaments, industrial and agricultural wastewater, in natura sewage containing unused drugs or non-metabolized compounds present in urine and feces. In natural sewage and treated effluents are the main sources of contamination of water bodies [1]. Additionally, given the long-term persistence and high bioaccumulation tendency of EDC pollutants, several efforts have been devoted to defining highly selective and sensitive analytical approaches for the detection of traces of such harmful pollutants in the environment. At the same time, many different treatment methods are being widely investigated for the purification of wastewater from EDCs [29], as described in the following sections.

\section{Chemical Degradation Approaches}

The strategies for the removal of organic contaminants from water involve physical, chemical, or biological processes. Physical separation of target compounds from solution, e.g., by chemical precipitation or adsorption on a porous material, is a simple approach; however, it implies the issue of the following recovery or disposal of the contaminant. Chemical degradation by oxidative mechanisms is aimed at transforming the contaminant into less hazardous products, and ideally results in its complete mineralization to inorganic compounds such as $\mathrm{CO}_{2}$ and $\mathrm{H}_{2} \mathrm{O}$. Biological treatments exploiting bacteria or other 
microorganisms may also achieve decomposition, nonetheless they usually require strictly controlled operating conditions and offer slow removal kinetics.

Conventional processes carried out in wastewater treatment plants and during the remediation of polluted water show poor efficiency in the elimination of several persistent and recalcitrant organic contaminants, as most EDCs. To supplement the well-established treatment technologies, advanced oxidation processes (AOPs) have emerged in the last three decades as a series of water purification techniques operating at or near ambient temperature and pressure, based on the generation of highly reactive and non-selective species, in particular reactive oxygen species (ROS). The principal ROS are hydroxyl radical $(\bullet \mathrm{OH})$, superoxide radical $\left(\bullet \mathrm{O}_{2}{ }^{-}\right)$, hydrogen peroxide $\left(\mathrm{H}_{2} \mathrm{O}_{2}\right)$ and singlet oxygen $\left({ }^{1} \mathrm{O}_{2}\right)$. A broader definition of ROS includes ozone $\left(\mathrm{O}_{3}\right)$, widely used for water decontamination and disinfection, and organic peroxyl radicals (ROO•). Oxidative processes can also be mediated by other chemical species, among them reactive nitrogen species (e.g., nitric oxide, $\mathrm{NO} \bullet$ ), sulfate radicals $\left(\mathrm{SO}_{4} \bullet^{-}\right)$and halogen-based oxidants (such as $\mathrm{HOCl}$ ) [30]. In living organisms, ROS play important physiological roles; on the other hand, an excess in their concentration causes oxidative stress and damage to cells. With the aim of exploiting the oxidative potential of such species against organic pollutants, a variety of methods for their production or activation is available. AOPs include ozonation, sonolysis, Fenton processes, low-temperature plasma oxidation, photochemical degradation. A combination of these techniques is frequently applied to achieve better results, and UV irradiation is a common way to trigger the formation of ROS or enhance their yield, for example together with $\mathrm{H}_{2} \mathrm{O}_{2}$ and $\mathrm{Fe}(\mathrm{II})$ salts (photo-Fenton), $\mathrm{O}_{3}$ (UV/ozonation) or semiconducting solids (heterogeneous photocatalysis) [1,31].

Most AOPs are homogeneous and require the use of radical precursors, stoichiometric reactants and/or high energy input. Hence, their full-scale implementation is still hindered by some practical limitations, for example the high operation cost, large consumption of reactive compounds, or the sensitivity to various organic and inorganic radical scavengers naturally present in wastewaters (e.g., humic acids, mineral anions) [32]. Heterogeneous water purification processes based on efficient solid catalysts that can be easily separated and reused are considered to offer advantages in terms of environmental sustainability and cost-effectiveness. Their development is therefore sought in view of scale-up and industrialization. Metal oxide semiconductors have acquired huge importance in this field, through photocatalysis as well as different catalytic mechanisms.

\subsection{Photocatalytic Processes}

Photocatalysis is a low-cost and versatile green technology widely used for the degradation of organic pollutants such as EDCs [33-36]. Photocatalytic processes need a semiconductor acting as photocatalyst that absorbs light radiation in a specific wavelength range, thus resulting in the excitation of electron $\left(\mathrm{e}^{-}\right)$from the valence band (VB) to the conduction band (CB). This jump creates positive holes $\left(\mathrm{h}^{+}\right)$in the $\mathrm{VB}$ of the photocatalyst, as shown in Equation (1):

$$
\text { photocatalyst }+\mathrm{h} v \rightarrow \mathrm{h}^{+} \mathrm{VB}+\mathrm{e}^{-}{ }_{\mathrm{CB}}
$$

The holes in the VB split $\mathrm{H}_{2} \mathrm{O}$ molecules thus resulting in the generation of hydroxyl free radicals, while electrons in the $\mathrm{CB}$ are trapped by oxygen molecules to form superoxide radicals, as schematized in Equations (2) and (3):

$$
\begin{gathered}
\mathrm{h}^{+}{ }_{\mathrm{VB}}+\mathrm{H}_{2} \mathrm{O} \rightarrow \mathrm{H}^{+}+\bullet \mathrm{OH} \\
\mathrm{e}^{-}{ }_{\mathrm{CB}}+\mathrm{O}_{2} \rightarrow \bullet \mathrm{O}_{2}{ }^{-}
\end{gathered}
$$

Other reactions can occur among the various species, producing more $\bullet \mathrm{OH}$ radicals, as shown in Equations (4)-(6).

$$
\bullet \mathrm{O}_{2}{ }^{-}+\mathrm{H}^{+} \rightarrow \mathrm{HO}_{2} \bullet
$$




$$
\begin{gathered}
2 \mathrm{HO}_{2} \bullet \rightarrow \mathrm{H}_{2} \mathrm{O}_{2}+\mathrm{O}_{2} \\
\mathrm{H}_{2} \mathrm{O}_{2} \rightarrow 2 \bullet \mathrm{OH}
\end{gathered}
$$

The produced hydroxyl radicals can degrade organic pollutants, such as EDCs, which are adsorbed/absorbed on the catalyst surfaces through a series of controlled steps to give $\mathrm{CO}_{2}$ and $\mathrm{H}_{2} \mathrm{O}$, as schematized in Equation (7):

$$
\bullet \mathrm{OH}+\mathrm{EDC} \rightarrow \mathrm{CO}_{2}+\mathrm{H}_{2} \mathrm{O}
$$

In addition to the action of ROS, photogenerated holes may directly react with adsorbed organic targets to produce intermediates that can be eventually oxidized to $\mathrm{CO}_{2}$ and $\mathrm{H}_{2} \mathrm{O}$.

A huge number of studies have been devoted to the development of efficient and stable photocatalytic materials, starting from the most commonly studied photoactive semiconductors, i.e., titanium dioxide and zinc oxide. Notwithstanding the advancement of both fundamental understanding of photoinduced mechanisms and functional performances of a variety of photocatalysts, there are still important challenges to face, the main being the ineffective use of the solar radiation spectrum and the fast $\mathrm{e}^{-} / \mathrm{h}^{+}$recombination, whereby the electrons excited to CB recombine with the separated $\mathrm{h}^{+}$in the VB rapidly prior to creation of free radicals. In this view, many flexible strategies can be adopted: the use of specific semiconductors with a low VB-CB band gap energy $\left(\mathrm{E}_{\mathrm{g}}\right)$, the heterojunction of semiconductors with different $E_{g}$, the doping with metal or non-metal elements, the modification with organic molecules or carbon materials as photosensitizers or co-dopants, the engineering of structural defects, such as ion vacancies [35,37-40].

To optimize the decontamination efficiency, photoactive semiconductors can be integrated in a variety of combined water treatment and environmental remediation technologies. Among them, intimate coupling of photocatalysis and biodegradation (ICPB) is a prospective green technique, merging the advantages of both processes without the need for separate reactors. The key principle of ICPB is the transformation of bio-recalcitrant pollutants into biodegradable products by photocatalysis on the surface of porous carriers, which also act as support and protective scaffold for the active microorganisms that can complete the decomposition and mineralization [41,42]. Further examples of combined AOPs are described in the next section.

\subsection{Other Heterogeneous Catalytic Processes}

Although photocatalysis attracts the broadest interest among AOPs, alternative oxidative processes based on materials which do not need light irradiation are the object of growing research efforts. Such approaches allow overcoming the limitations of photoinduced processes, in particular the use of artificial UV or visible light sources and the constraints in the design of photoreactors to maximize the penetration and absorption of radiation.

A relevant case is the heterogenized Fenton and Fenton-like process. Fenton reaction consists in the oxidation of $\mathrm{Fe}(\mathrm{II})$ to $\mathrm{Fe}(\mathrm{III})$ inducing the decomposition of $\mathrm{H}_{2} \mathrm{O}_{2}$ with formation of hydroxyl radicals:

$$
\mathrm{Fe}^{2+}+\mathrm{H}_{2} \mathrm{O}_{2} \rightarrow \mathrm{Fe}^{3+}+\mathrm{HO}^{-}+\bullet \mathrm{OH}
$$

Ferric ions can react with $\mathrm{H}_{2} \mathrm{O}_{2}$ as well, producing hydroperoxyl radicals $\left(\mathrm{HO}_{2} \bullet\right)$ and ferrous ions, in the so-called Fenton-like reaction:

$$
\mathrm{Fe}^{3+}+\mathrm{H}_{2} \mathrm{O}_{2} \rightarrow \mathrm{Fe}^{2+}+\mathrm{HO}_{2} \bullet+\mathrm{H}^{+}
$$

This process can be accelerated by coupling with UV irradiation (photo-Fenton) or electrocatalysis (electro-Fenton); nevertheless, shortcomings such as the requested optimum acid $\mathrm{pH}$ (around 3), the consumption of reactants, and their separation and subsequent 
sludge management limit its large-scale application [43]. Therefore, heterogeneous Fenton catalysts, including iron oxides, zerovalent iron and Fe species supported on a solid matrix, are gaining attention. Some of these materials show a reactivity comparable to homogeneous Fenton in a broad $\mathrm{pH}$ range, requiring low amounts of $\mathrm{H}_{2} \mathrm{O}_{2}$, and ensure high stability (low Fe leaching) [44]. Among iron oxides, magnetite $\left(\mathrm{Fe}_{3} \mathrm{O}_{4}\right)$ is the most suitable owing to its structure; however, hematite $\left(\alpha-\mathrm{Fe}_{2} \mathrm{O}_{3}\right)$, maghemite $\left(\gamma-\mathrm{Fe}_{2} \mathrm{O}_{3}\right)$ and goethite $(\alpha-\mathrm{FeOOH})$ have been found to be useful as well [43].

A promising alternative to Fenton is represented by AOPs (Advanced Oxidative Processes) based on sulfate radical $\left(\mathrm{SO}_{4} \bullet^{-}\right)$, which are emerging in recent years, as testified by the increasing number of related research articles and reviews [45-47]. Compared to $\bullet \mathrm{OH}, \mathrm{SO}_{4} \bullet^{-}$has a similar or even higher oxidation potential (2.5-3.1 V vs. NHE) and a longer half-life in water (about $30-40 \mu$ s vs. $20 \mathrm{~ns}$ ), so it can migrate longer distances to reach target contaminants. Moreover, sulfate radicals work in aqueous solution on a wider $\mathrm{pH}$ range (2-8) and are more selective toward organics containing unsaturated or aromatic bonds [45]. The two major sources of this reactive species are peroxymonosulfate (PMS, $\mathrm{HSO}_{5}{ }^{-}$) and persulfate (PS, $\mathrm{S}_{2} \mathrm{O}_{8}{ }^{2-}$ ) anions. The use of their salts is advantageous because of the low cost, safety and easy transportation and handling, making the in situ chemical oxidation feasible for groundwater and soil remediation [46]. PMS and PS can be activated by various methods, including heating, UV irradiation, ultrasounds, alkaline medium and some transition metals ( $\mathrm{Fe}, \mathrm{Co}, \mathrm{Mn}, \mathrm{Cu}, \mathrm{Ni}, \mathrm{Ce}, \mathrm{V}, \mathrm{Ag}$ ), in homogeneous or heterogeneous systems [45]. The activation of PMS and PS by a metal ion $\left(\mathrm{M}^{\mathrm{n}+}\right)$ can be schematized, respectively, as follows:

$$
\begin{aligned}
& \mathrm{HSO}_{5}{ }^{-}+\mathrm{M}^{\mathrm{n}+} \rightarrow \mathrm{M}^{(\mathrm{n}+1)+}+\mathrm{SO}_{4} \bullet^{-}+\mathrm{OH}^{-} \\
& \mathrm{S}_{2} \mathrm{O}_{8}{ }^{2-}+\mathrm{M}^{\mathrm{n}+} \rightarrow \mathrm{M}^{(\mathrm{n}+1)+}+\mathrm{SO}_{4} \bullet^{-}+\mathrm{SO}_{4}{ }^{2-}
\end{aligned}
$$

Oxides of $\mathrm{Fe}^{2+}, \mathrm{Fe}^{3+}, \mathrm{Co}^{3+}$ and $\mathrm{Mn}^{2+}$, often in mixed heterostructures, are the most studied solid catalysts for the generation of sulfate radicals in water treatment strategies [47]. The reaction networks in presence of sulfate radicals can involve the formation of ROS like hydroxyl and superoxide radicals, leading to multifarious oxidation mechanisms [46].

Another attractive strategy to obtain ROS active in the absence of continuous irradiation is the modification of metal oxide semiconductors with suitable organic molecules, forming interfacial charge transfer complexes. These can give the ability to activate molecular $\mathrm{O}_{2}$ by spontaneous reduction to superoxide, as recently observed for titanium and zirconium oxides with coordinated diketone ligands [48-51]. On the surface of such hybrid materials the generated $\bullet \mathrm{O}_{2}{ }^{-}$radicals can be stabilized for exceptionally long times, leading to oxidative degradation of organic water contaminants even in dark conditions [50,52].

Electrocatalysis is a well-known technology applicable to the decomposition of pollutants with relatively high concentration. Nanostructured metal oxides can be employed as electrodes in electrochemical oxidation processes, frequently coupled with light irradiation (photoelectrocatalysis) or other techniques to enhance the efficiency.

An innovative set of AOPs takes advantage of piezoelectric catalysis, or piezocatalysis, a field that has emerged in recent years. It is based on the piezoelectric effect, namely the ability of materials with non-centrosymmetric structure to generate charge separation because of deformation in the presence of external mechanical energy. The possible sources of mechanical energy include ultrasonic cavitation, physical bending, and vortex-induced shearing force. If the potential of the built-in electric field created by the dipole polarization is sufficient, the charge carriers reaching the surface of the materials can accumulate and induce redox reactions, for example generating ROS or directly oxidizing adsorbed molecules. This piezo-catalytic effect was therefore proposed as AOP, either by itself or coupled with irradiation and/or Fenton process [53,54]. Among the piezoelectric ceramics, $\mathrm{ZnO}$ and titanates, $\mathrm{BaTiO}_{3}$ and $\mathrm{Pb}(\mathrm{Zr}, \mathrm{Ti}) \mathrm{O}_{3}$, have been successfully tested for the degradation of organic pollutants. $1 \mathrm{D}$ and $2 \mathrm{D}$ nanomaterials possess high flexibility under mechanical forces and hence are expected to show better piezo-catalytic performances. Beside morphology, 
the presence of defects producing free charge carriers should be another crucial factor in driving this kind of catalytic activity [53].

Non-thermal plasma technologies, being able to generate reactive species at relatively low temperature, are emerging as candidates for the treatment of contaminated water. The combination of non-thermal plasma with other AOPs, in particular, heterogeneous catalysis, has been proposed to enhance pollutant degradation performances and reduce the formation of reaction by-products. There are different types of reactor configurations, the most used being the dielectric barrier discharge. Solid (photo)catalysts can be the introduced in various forms, as foam, honeycomb monolith, coating on the reactor walls or electrodes, or as a packed bed [55]. Different metal oxide semiconductors have been integrated in non-plasma systems, improving the degradation efficiency of emerging contaminants and thus making the process more economically sustainable [56]. Another possible advantage is the ability of non-thermal plasma to regenerate the catalyst inserted in the reactor. Finally, metal oxides can also be employed in catalytic wet air (or peroxide) oxidation, where oxygen ( $\mathrm{or}_{2} \mathrm{O}_{2}$ ) is dissolved in the liquid phase at high temperatures and pressures. This review focuses on reactions performed at low temperature and ambient pressure, so these treatment techniques are not covered.

The research on efficient oxidative processes based on nanomaterials is constantly evolving, and thus new achievements are expected soon. In the following section, recent results in the application of metal oxide-based (photo)catalysts in the removal of EDCs from water are presented.

\section{Metal Oxide-Based Nanomaterials for EDCs Removal}

This section reports a selection of recent literature studies on metal oxides and related nanomaterials applied in the heterogeneous degradation of endocrine disruptors in water. The classification is based on the most extensively represented groups of EDCs considered as target contaminants, namely, components and additives of plastic materials, chemicals used in agricultural activities, pharmaceutical, and personal care products and other relevant compounds not included in these categories.

\subsection{Photocatalytic and Catalytic Degradation of Plastic Components and Additives}

The awareness about plastic and microplastic pollution is finally rising as the adverse effects of many components of common polymeric materials are acknowledged. The massive production and ubiquitous use of plastics (often as disposable items), followed by frequent incorrect disposal, causes the significant presence of these chemicals in sewage. Among EDCs, plasticizers, such as phthalates, chlorinated solvents and additives, and bisphenols (e.g., Bisphenol A (BPA), Bisphenol F (BPF), Bisphenol AF (BPAF) and Bisphenol $\mathrm{S}$ (BPS)), the main monomers of epoxy resins (Figure 2), raise large concern. Among the bisphenols, BPA is the most used organic compound in the synthesis and manufacturing of epoxy resins.

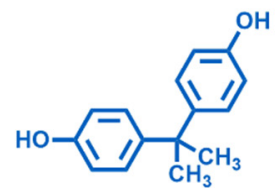

Bisphenol A (BPA)

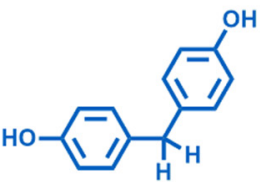

Bisphenol F (BPF)

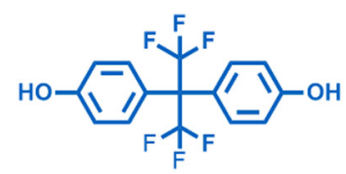

Bisphenol AF(BPAF)

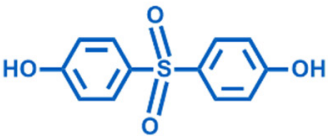

Bisphenol S (BPS)

Figure 2. Chemical structures of Bisphenol A (BPA), Bisphenol F (BPF), Bisphenol AF (BPAF) and Bisphenol S (BPS).

BPA is considered an EDC which negatively affects the environment when it is released in water or atmosphere [57] and human health when it enters the body, being able to interfere with the endocrine system, thus possibly causing reproductive and developmental disorders and diseases of the immune and nervous systems [58]. BPA is widely present in the aquatic environment, because it is used in the production of polycarbonate, epoxy 
resin and exploited in many plastic products, such as milk packaging and beverage cans in the food industry [59]. Considering human health, the United States Environmental Protection Agency (US EPA) strongly recommended a reference limit dose for oral exposure of $50 \mu \mathrm{g} \mathrm{BPA} / \mathrm{kg}$ of body weight/day in 2014 [60]. In view of the above, the removal of BPA from wastewater is a critical issue at present. Phthalic acid esters (PAEs), or phthalates, are typical EDCs and a chemical class of plasticizers used in many plastic products. The ubiquitous presence of PAEs makes them detected everywhere as result of release to water, atmosphere and soil [61]. The scientific community agrees on the role of anthropogenic activities as the primary contributor to the occurrence of bisphenols and phthalate monoesters in lakes, lagoons, and their sediments, caused by the discharge of domestic and industrial waste and wastewater, as well as farming, transportation, etc. [62,63]. The major species detected between the phthalates in the influents of wastewater treatment plants are dimethyl phthalate (DMP), diethyl phthalate (DEP), dibutyl phthalate (DBP) (Figure 3).

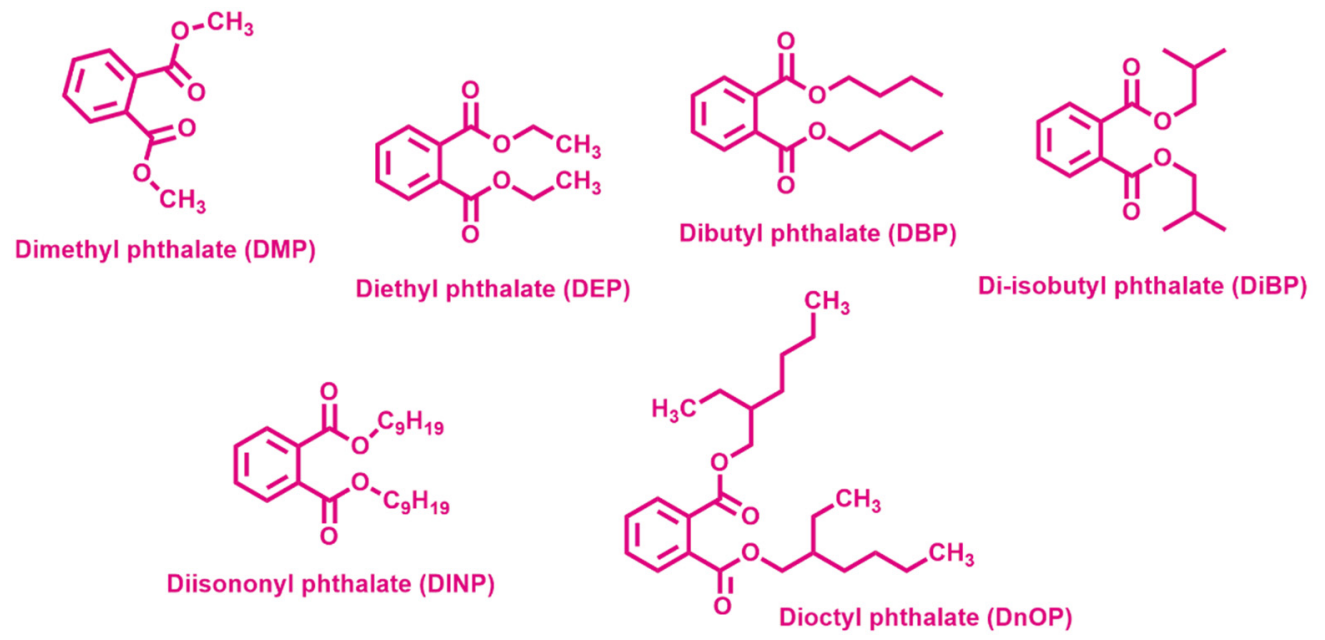

Figure 3. Chemical structures of the most used phthalates.

DBP has been shown to tend to accumulate in the sludge with a maximum detection of $2497 \mu \mathrm{g} / \mathrm{L}$, exceeding acceptable levels for a safe aquatic environment [64]. Prominent levels of typical phthalates, including di-isobutyl phthalate (DiBP), DBP and di(2ethylhexyl) phthalate (DEHP) have been found from researchers in both Chinese and French hospitals [65].

The willingness to move toward a more sustainable society and the increasing demand of reducing pollution have boosted the synthesis of new more efficient catalysts and photocatalysts for the degradation of BPA and phthalates. In the recent period, there has been growing interest in the development of doped and hybrid materials based on metal oxides with significant performances in degradation of these plastic derivatives. The main aspects related to oxidative mechanisms as well as chemical features and synthesis of the most representative nanostructured catalysts and photocatalysts are described in the next paragraphs.

\subsubsection{Bisphenol A}

Among the titanium oxide-based photocatalysts, composites with graphene or reduced graphene oxide (rGO) were intensively investigated. $\mathrm{Xu}$ et al. [66] synthetized $\mathrm{TiO}_{2-x} / \mathrm{rGO}$ nanocomposite via hydrothermal-calcination method, where $\mathrm{TiO}_{2}$ was selfdoped by $\mathrm{Ti}^{3+}$ and oxygen vacancies $\left(\mathrm{Ti}^{3+} / \mathrm{Ov}\right)$. The presence of $\mathrm{Ti}^{3+} / \mathrm{Ov}$ in the oxide lattice led to enhanced visible light harvesting and the chemical bonds (Ti-O-C) between $\mathrm{TiO}_{2-\mathrm{x}}$ and $\mathrm{rGO}$ allowed for an efficient charge separation. Furthermore, the coupling of $\mathrm{TiO}_{2-x}$ and rGO prevented the aggregation of $\mathrm{TiO}_{2-x}$ particles and thus improved the adsorption of organic pollutants. $\mathrm{TiO}_{2-x} / \mathrm{rGO}$ exerted a 6.16-, 2.92- and 2.55-fold faster reaction rate for $\mathrm{BPA}$ degradation than that of unmodified $\mathrm{TiO}_{2}, \mathrm{TiO}_{2} / \mathrm{rGO}$ and $\mathrm{TiO}_{2-\mathrm{x}}$, re- 
spectively. Chemical analysis showed that $\bullet \mathrm{O}_{2}{ }^{-}$radicals were the major oxidizing species, therefore responsible for a maximum of approximately 91\% BPA removal after $60 \mathrm{~min}$. Wang et al. [67] synthesized a $\mathrm{TiO}_{2} @$ aspartic acid- $\beta$-cyclodextrin@rGO $\left(\mathrm{TiO}_{2} @ \mathrm{ACD} @ \mathrm{rGO}\right)$ composite photocatalyst by a photochemical method and applied it in the degradation of BPA under UV irradiation. TiO $\mathrm{T}_{2} @ \mathrm{ACD} @ \mathrm{rGO}$ exhibited higher photocatalytic efficiency than $\mathrm{TiO}_{2}$ and $\mathrm{TiO}_{2} @ \mathrm{rGO}$, resulting in a reaction constant for BPA of $0.739 \mathrm{mg} / \mathrm{L} \cdot \mathrm{min}$, which was almost two times its counterparts. The removal efficiency of $\mathrm{BPA}$ by $\mathrm{TiO}_{2} @ \mathrm{ACD} @ \mathrm{rGO}$ could achieve a value of $85.6 \%$ after 60 min under UV irradiation, which is $10 \%$ and $24.2 \%$ higher than that of $\mathrm{BPA}$ by $\mathrm{TiO}_{2} @ \mathrm{rGO}$ and $\mathrm{TiO}_{2}$, respectively. $\mathrm{TiO}_{2} @ \mathrm{ACD} @ \mathrm{rGO}$ exerted its degradation activity through the release of superoxide radicals and $\mathrm{h}^{+}$, which was boosted by effective electron and mass transfers at the photocatalyst interface (Figure 4). Moreover, the composite exhibited good stability and reusability after five cycles. The chemical investigation revealed that the modified cyclodextrins strengthen the adsorption of BPA on the photocatalyst surface.

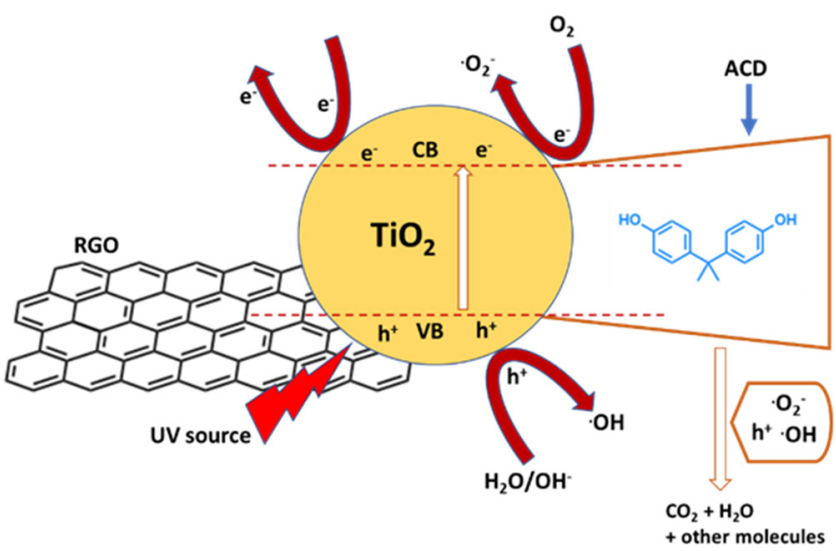

Figure 4. Reaction mechanism of photocatalytic degradation of BPA in the $\mathrm{TiO}_{2} @ \mathrm{ACD} @ \mathrm{rGO}$ system, where ACD is aspartic acid-cyclodextrin compound. Adapted and reprinted with permission from [67], Copyright (2021) Elsevier.

On the other hand, Wang et al. [68] synthetized via a hydrothermal approach Fedoped $\mathrm{TiO}_{2} / \mathrm{rGO}$ active under visible light. Fe-TiO $/$ rGO nanocomposites exerted high photocatalytic performance for BPA and its analogues (Figure 2), especially when BPA concentration was around $95 \mathrm{ppm}$ and $\mathrm{pH}$ in the range 4.5-8.5. The doping Fe as well as GO significantly boosted photocatalytic activity, resulting in an increase of BPA degradation rate compared to pristine samples. The photocatalytic degradation, mainly led by $\bullet \mathrm{O}_{2}{ }^{-}$ radicals, was promoted by the presence of $\mathrm{Ti}^{3+}$ and by the formation of $\mathrm{Fe}^{+}\left(\mathrm{C}_{6} \mathrm{H}_{5} \mathrm{OH}\right)$ $\pi$-complex. Approximately $25 \%$ of $\mathrm{BPA}$ was adsorbed by $\mathrm{Fe}-\mathrm{TiO}_{2} / \mathrm{rGO}$ after $30 \mathrm{~min}$ in the dark, and BPA was completely removed within 60 min under visible-light irradiation. Additionally, BPF and BPAF were completely degraded after $120 \mathrm{~min}$, and $96 \%$ of BPS was removed within 120 min under visible-light irradiation.

Additionally, Garg et al. [69] synthetized via a wet impregnation method $\mathrm{TiO}_{2}$ codoped with visible-light photoactive cobalt and nitrogen to enhance pollutants degradation. The photocatalytic activity on the mineralization of BPA under visible-light irradiation was compared to commercial $\mathrm{TiO}_{2}$ (Degussa P25). In particular, $1.5 \%$ Co and $0.5 \% \mathrm{~N}$ co-doped $\mathrm{TiO}_{2}$ sample showed the highest degradation activity: the complete mineralization of BPA and 97\% removal of total organic carbon (TOC) were observed. The performances were associated with alterations in physical properties, crystal structure and energy band gap induced by the dopants. Zhao et al. [70] prepared $\mathrm{Fe}_{3} \mathrm{O}_{4} @ \mathrm{mTiO}_{2} / \mathrm{C}$ through the combination of mesoporous $\mathrm{TiO}_{2}, \mathrm{Fe}_{3} \mathrm{O}_{4}$ and carbon. It exhibited intense light response in the visible light region because of the dual sensitization effect and double conductivity, which was beneficial to the transfer and separation of charge carriers, i.e., photogenerated electrons and holes (Figure 5). This double conductive structure of $\mathrm{Fe}_{3} \mathrm{O}_{4} @ \mathrm{mTiO}_{2} / \mathrm{C}$ 
photocatalyst allowed for a significant activity in the complete degradation of BPA in $120 \mathrm{~min}$ under visible light and superior stability for its reusability after five cycles.

\section{Potential vs NHE}

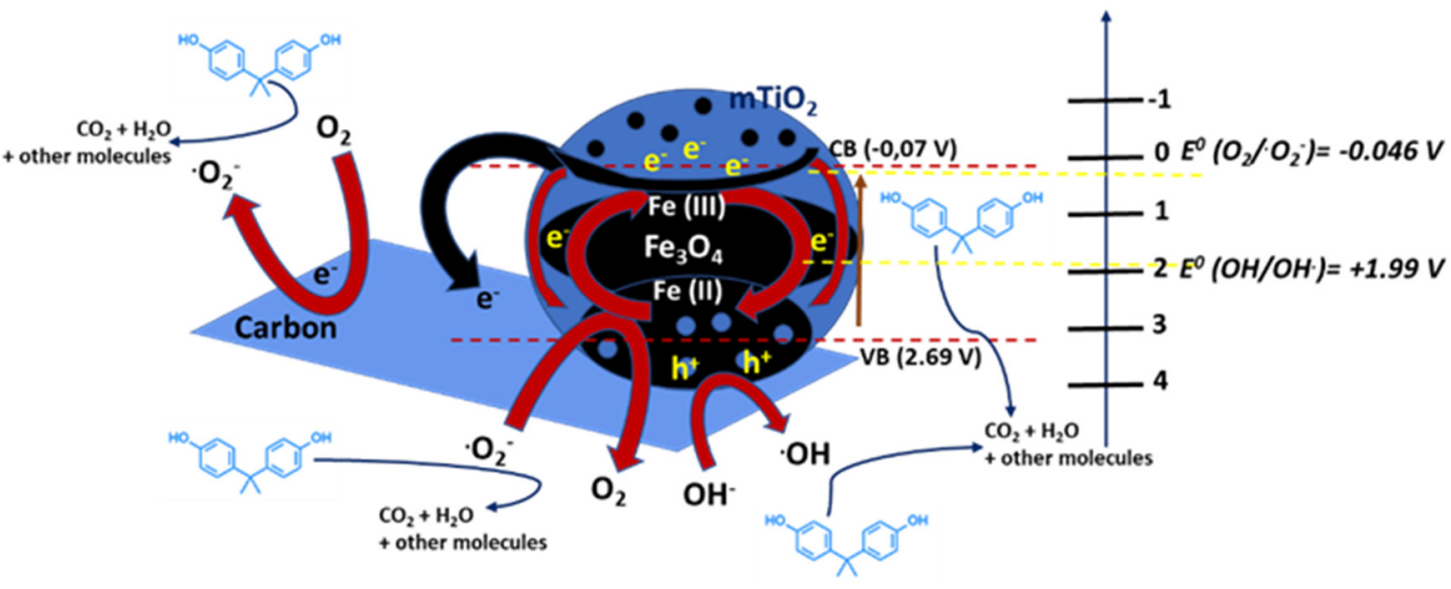

Figure 5. Possible photocatalytic mechanism of the $\mathrm{Fe}_{3} \mathrm{O}_{4} @ \mathrm{mTiO}_{2} / \mathrm{C}$ sample. Adapted and reprinted with permission from [70], Copyright (2021) Elsevier.

He et al. [71] synthetized a magnetic composite material, $\mathrm{Ag} / \mathrm{Fe}, \mathrm{N}-\mathrm{TiO}_{2} / \mathrm{Fe}_{3} \mathrm{O}_{4} @ \mathrm{SiO}_{2}$ (AgFeNTFS), for the visible-light-driven photocatalytic disinfection of Escherichia coli (E. coli) and degradation of BPA. The photocatalyst completely removed BPA (2 mg/L) and showed 6.3-log reduction in cell density of $E$. coli within $120 \mathrm{~min}$. In presence of both BPA and E. coli in the treated water sample (i.e., sewage obtained from a wastewater treatment plant), the efficiency of AgFeNTFS in the BPA degradation was dropped by 10\%, due to the competition for the same reactive species of $\mathrm{O}_{2}$ and $\mathrm{H}_{2} \mathrm{O}_{2}$ between the two contaminants. However, the treated water sample could meet local disinfection discharge standard with a 3-log reduction (99.9\%) of E. coli after 90 min and a simultaneous complete removal of BPA after $360 \mathrm{~min}$. Ju et al. [72] prepared ZnAlTi layered double oxide (ZnAlTiLDO)-supported C60@AgCl nanoparticles (C60@AgCl-LDO) for the photo-degradation of BPA under simulated visible-light irradiation. C60@AgCl-LDO showed a characteristic mesoporous structure. The Ag@AgCl heterostructure boosted the near-field for light scattering, reflection, and absorption. Fullerene enhanced the stability of Ag-based phase, so the $\mathrm{C} 60 @ \mathrm{AgCl}$ reduced the recombination of photo-induced electron-hole pairs, and therefore increased the efficiency of photocatalysis. The chemical investigation showed that photogenerated $\mathrm{h}^{+}$, superoxide radical, $\bullet \mathrm{OH}$ bulk, and singlet oxygen were responsible for the extremely fast photodegradation, allowing a BPA removal of $100 \%$ by using C60@ AgClLDO under ultraviolet light in $5 \mathrm{~min}$. Kumar et al. [73] prepared a graphitic carbon nitride $\left(\mathrm{g}-\mathrm{C}_{3} \mathrm{~N}_{4}\right)-\mathrm{CaTiO}_{3}(\mathrm{CTCN})$ organic-inorganic heterojunction photocatalyst through a mixing methodology and the deposition of calcium titanate (CT) nanoflakes onto the surface of $\mathrm{g}-\mathrm{C}_{3} \mathrm{~N}_{4}(\mathrm{CN})$ nanosheets. The CTCN heterojunction with $1: 1$ ratio of $\mathrm{g}-\mathrm{C}_{3} \mathrm{~N}_{4} / \mathrm{CT}$ exhibited the highest photocatalytic activity under sunlight irradiation, resulting in the $47 \%$ degradation of BPA after $120 \mathrm{~min}$. The presence of the two-dimensional (2D) morphology of $\mathrm{g}-\mathrm{C}_{3} \mathrm{~N}_{4}$ nanosheets and $\mathrm{CT}$ nanoflakes provided a vast number of reaction sites with large surface area, and thus enhanced the overall photocatalytic activity. The chemical analysis of photocatalytic process confirmed that $\bullet \mathrm{O}_{2}{ }^{-}$radicals exerted the key role in the degradation of BPA.

Bismuth-based semiconductors are attracting increasing research interest for their tunable properties and wide absorption spectrum. Bismuth mixed metal oxides or oxyhalides are particularly investigated. For example, Ma et al. [74] synthetized a polythiophene (PTh) $/ \mathrm{Bi}_{4} \mathrm{O}_{5} \mathrm{I}_{2}$ hybrid by sol-gel. The incorporation of conductive polythiophene enhanced the separation efficiency of photo-charge carriers, boosting the visible light photocatalytic 
ability of $\mathrm{Bi}_{4} \mathrm{O}_{5} \mathrm{I}_{2}$. This led to a BPA degradation of $99.2 \%$ in $30 \mathrm{~min}$ with $0.5 \mathrm{wt} \%$ of PTh, with a reaction rate 3.7 times higher than on pristine $\mathrm{Bi}_{4} \mathrm{O}_{5} \mathrm{I}_{2}$. Wu et al. [75] prepared, by a wet-chemical methodology, three BiOI samples with different morphologies (nanoplate, micro-flower, microsphere) and $\mathrm{Bi}_{2} \mathrm{WO}_{6} / \mathrm{BiOI}$ microspheres, by a microwave-assisted synthetic method with different ratios of $\mathrm{Bi}_{2} \mathrm{WO}_{6}$. The chemical investigation proved that BiOI-3 microspheres showed higher photocatalytic activity than other morphologies (BiOI-1 and $\mathrm{BiOI}-2$ ) in the degradation of $\mathrm{BPA}$ and methyl orange, furthermore, $\mathrm{Bi}_{2} \mathrm{WO}_{6} / \mathrm{BiOI}$ (BWOI-3) with $3 \%$ content of $\mathrm{Bi}_{2} \mathrm{WO}_{6}$ exhibited the best photocatalytic performance as well as a good durability. $\mathrm{Bi}_{2} \mathrm{WO}_{6} / \mathrm{BiOI}$ was highly effective due to a significant production of reactive species $\left(\mathrm{h}^{+}, \bullet \mathrm{O}_{2}{ }^{-}\right)$and a synergistic effect between p-type $\mathrm{BiOI}$ and n-type $\mathrm{Bi}_{2} \mathrm{WO}_{6}$, which could promote the separation of electron-hole pairs. Finally, BWOI-3 showed a photodegradation efficiency up to $95.04 \%$ for $\mathrm{MO}$ and $86.84 \%$ for BPA under visible-light for $60 \mathrm{~min}$ and $100 \mathrm{~min}$, respectively. Rao et al. [76] prepared a ternary $\mathrm{Pd} / \mathrm{PdO} / \beta-\mathrm{Bi}_{2} \mathrm{O}_{3}$ composite photocatalyst with different amounts of $\mathrm{Pd} / \mathrm{PdO}$ by a simple two-step process. The material was characterized by a heterojunction ( $\mathrm{p}-\mathrm{n}$ junction) of $\mathrm{PdO} / \beta-\mathrm{Bi}_{2} \mathrm{O}_{3}$ and the Schottky barrier of $\mathrm{Pd} / \beta-\mathrm{Bi}_{2} \mathrm{O}_{3}$, which significantly limited the recombination of photoinduced electron-hole pairs in the composite, increasing visible light absorption and improving charge separation efficiency between $\mathrm{Pd}, \mathrm{PdO}$ and $\beta-\mathrm{Bi}_{2} \mathrm{O}_{3}$. In particular, $1.0 \mathrm{wt} \%$ of $\mathrm{Pd} / \mathrm{PdO} / \beta-\mathrm{Bi}_{2} \mathrm{O}_{3}$ showed an excellent photocatalytic activity for BPA degradation and nitric oxide (NO) removal, $97.4 \%$ and $47.6 \%$, respectively, within $30 \mathrm{~min}$, outperforming pure $\beta-\mathrm{Bi}_{2} \mathrm{O}_{3}$. Both hydroxyl and superoxide radicals were involved in the photocatalytic process. Li et al. [77] synthetized via solvothermal-reduction method $\mathrm{Bi}_{4} \mathrm{O}_{5} \mathrm{Br}_{2}$ nanosheets loaded with $\mathrm{Pd}$ nanoparticles for the of $\mathrm{BPA}$. $\mathrm{Pd} / \mathrm{Bi}_{4} \mathrm{O}_{5} \mathrm{Br}_{2}$ showed higher photocatalytic activity and photocurrent response than pure $\mathrm{Bi}_{4} \mathrm{O}_{5} \mathrm{Br}_{2}$. In particular, $1.0 \mathrm{wt} \%$ loading of $\mathrm{Pd}$ was found to be most effective for improving the BPA removal rate constant and achieve a degradation of BPA near to $95.8 \%$ after 70 min LED visible-light irradiation. The enhanced performances of $\mathrm{Pd} / \mathrm{Bi}_{4} \mathrm{O}_{5} \mathrm{Br}_{2}$ were attributed to the formation of a Schottky barrier between the $\mathrm{Pd}$ nanoparticle and the $\mathrm{Bi}_{4} \mathrm{O}_{5} \mathrm{Br}_{2}$ nanosheet, effectively promoting the separation of photogenerated electrons and holes (Figure 6).

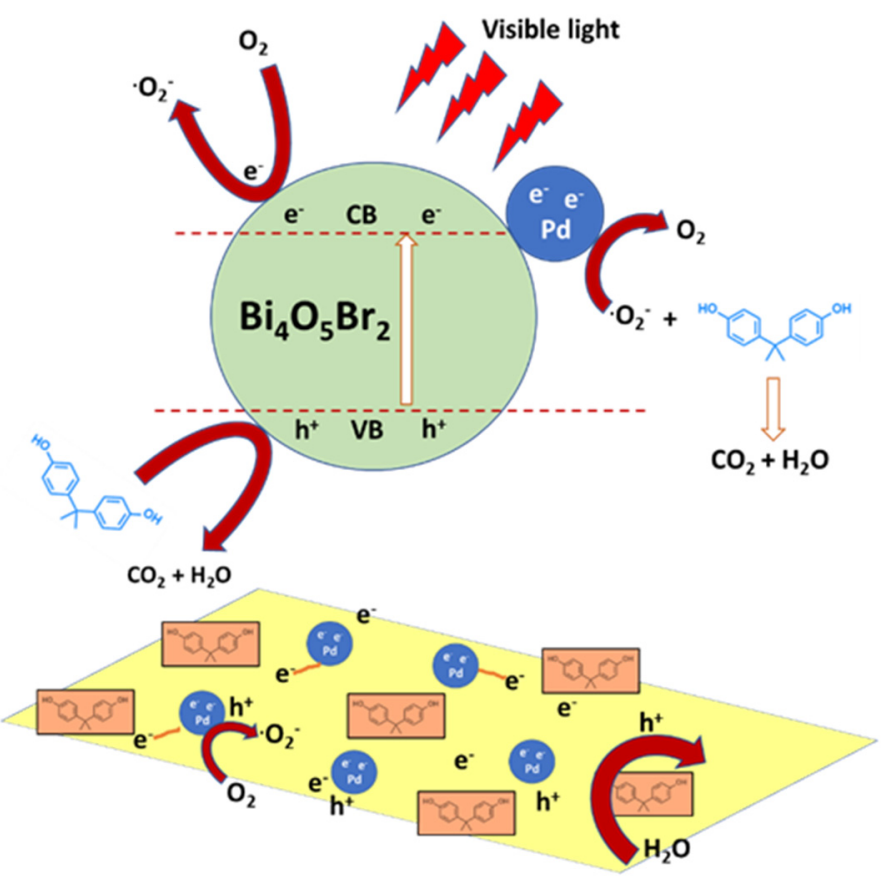

Figure 6. Schematic representation of the photodegradation of BPA over a semiconductor decorated with noble metal nanoparticles, $\mathrm{Pd} / \mathrm{Bi}_{4} \mathrm{O}_{5} \mathrm{Br}_{2}$, under visible-light irradiation. Adapted and reprinted with permission from [77], Copyright (2018) Elsevier. 
$\mathrm{Xu}$ et al. [78] synthetized different $\mathrm{Ag}_{3} \mathrm{PO}_{4}$ structures to degrade $\mathrm{BPA}$ under visiblelight irradiation. The degradation of $\mathrm{BPA}$ after $30 \mathrm{~min}$ was $27 \%$ by using cubic $\mathrm{Ag}_{3} \mathrm{PO}_{4}$, whereas it was almost $100 \%$ by the nano-flake $\mathrm{Ag}_{3} \mathrm{PO}_{4}$ photocatalyst, resulting in a rate constant 9.71 times higher. The performances were attributed to the action of $\mathrm{h}^{+}$and $-\mathrm{O}_{2}{ }^{-}$. The extended light adsorption and accelerated carrier transfer promoted a high photocatalytic activity, where both were accounted for by the increasing number of exposed (111) crystals and catalytic active sites on $\mathrm{Ag}_{3} \mathrm{PO}_{4}$ nano-flakes. Selvakumar et al. [79] prepared by hydrothermal process a $\mathrm{Gd}_{2} \mathrm{WO}_{6} / \mathrm{ZnO} /$ bentonite (GWZB) nanocomposite. It showed a strong decrease in the rate of electron-hole recombination, resulting in a higher photocatalytic activity compared to pure GWZ without bentonite. GWZB was characterized by clustered microsponge-like structure and exerted an effective degradation under visible light of ciprofloxacin (CF) and BPA with good recycling performance. The photodegradation of CF and BPA with $20 \mathrm{mg}$ of GWZB were 97.9 and $98.3 \%$ respectively, due to the action of superoxide radicals (Figure 7).

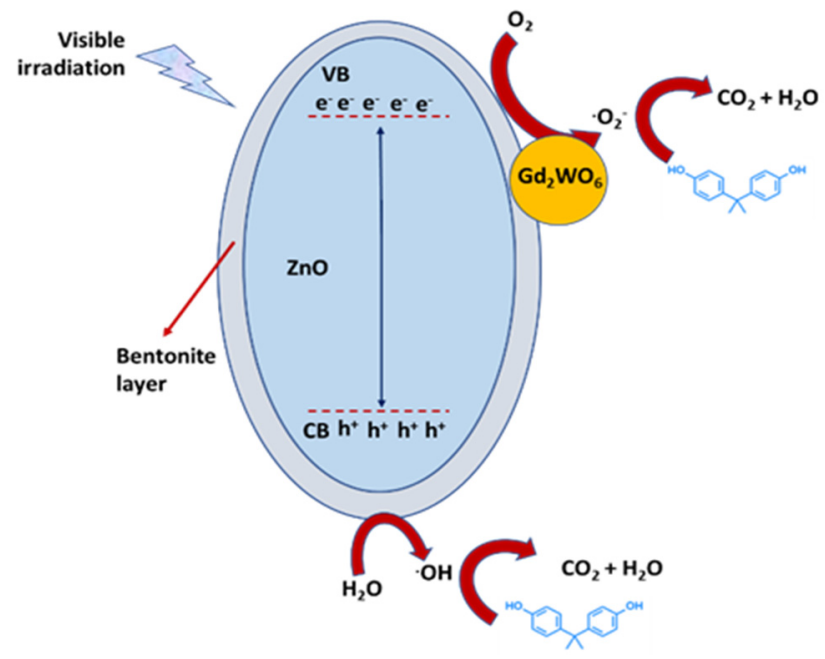

Figure 7. Proposed mechanism for the photodegradation of organic pollutants on a $\mathrm{Gd}_{2} \mathrm{WO}_{6} / \mathrm{ZnO} /$ bentonite ternary composite, as described into [79].

Sulfate-based AOPs have become relevant non-photoinduced technologies for the decomposition of emerging contaminants. Fu et al. [80] prepared three novel composites of graphitized hierarchical porous biochar (MX) with magnetic manganese ferrite $\left(\mathrm{MnFe}_{2} \mathrm{O}_{4} / \mathrm{MX}\right)$, which could activate peroxymonosulfate (PMS). The material was aimed at the degradation of a range of contaminants: bisphenol A, orange II, methylene blue, sulfadiazine, and ciprofloxacin. MX included MS, ML, MC synthesized using corn stems (S), leaves (L) and cores (C) as raw waste materials, respectively, possessed hierarchical porous structure, graphitization domains and tremendous surface area. The degradation efficiency was boosted with increasing PMS dose, catalyst dose, reaction temperature, and reducing organic pollutant concentration. Three pathways were involved in the catalytic activity of $\mathrm{MnFe}_{2} \mathrm{O}_{4} / \mathrm{MS}$, including radical-induced oxidation attained by surface-bound $\mathrm{SO}_{4} \bullet^{-}$ and $\bullet \mathrm{OH}$ on $\mathrm{MnFe}_{2} \mathrm{O}_{4}$ nanoclusters and hierarchical porous carbon sheets, non-radical pathway ascribed to $\bullet \mathrm{O}_{2}{ }^{-}$generated by promoted self-decomposition of PMS, non-radical pathway achieved through electron transfer from organic compounds to PMS mediated by graphitized structures. In addition, $\mathrm{MnFe}_{2} \mathrm{O}_{4} / \mathrm{MS}$ has the advantages of wide $\mathrm{pH}$ usable range. $\mathrm{MnFe}_{2} \mathrm{O}_{4} / \mathrm{MS}$ and PMS system could degrade orange II/methylene blue, bisphenol A, sulfadiazine, and ciprofloxacin with a removal efficiency of $100 \%, 95 \%, 91 \%$ and $85 \%$, respectively.

Kong et al. [81] synthetized a stable $\mathrm{Cu}_{2} \mathrm{O} @ \beta-\mathrm{CD}$ through topotaxial conversion of $\mathrm{CuCl}$ assisted by $\beta-\mathrm{CD}$ ( $\beta$-cyclodextrin) at room temperature. Fenton-like reaction is the most widespread method for removal of organic pollutants, but their reactivity with $\mathrm{H}_{2} \mathrm{O}_{2}$ may be inhibited by natural organic matter (NOM) due to the competition of hydroxyl 
radicals and chelating agents. Covalently linked $\beta$-CD could keep humic acid (HA), which is present in the $\mathrm{NOM}$, from interfering catalytic performance of $\mathrm{Cu}_{2} \mathrm{O}$ surfaces and inhibited the leaching of copper. $\mathrm{Cu}_{2} \mathrm{O} @ \beta$-cyclodextrin could work in cooperation with Fenton-like catalysis to destruct aromatic pollutants at neutral $\mathrm{pH}$. $\beta-\mathrm{CD}$ with a hydrophobic cavity well anchored on $\mathrm{Cu}_{2} \mathrm{O}$ could exhibit selective adsorption to aromatic pollutants including bisphenol $\mathrm{A}$ and inhibited $\mathrm{HA}$ from bonding with available catalytic $(\mathrm{Cu})$ sites, showing active species $\bullet \mathrm{OH}$ on $\mathrm{Cu}_{2} \mathrm{O}$ surfaces and $83.7 \%$ BPA removal efficiency. In the emerging branch of piezocatalysis applied to water remediation, coupling with photocatalysis seems extremely promising. $\mathrm{ZnO}$ and titanate nanostructures were modified by the formation of heterojunctions or doping to enhance the piezo photocatalytic performances and some of these materials were tested in the removal of EDCs from water, in particular BPA. Zhang et al. coupled $\mathrm{ZnO}$ with $\mathrm{CdS}$ or BiOI, two semiconductors responsive to visible light, to promote the separation rate of charge carriers in addition to the piezoelectric field produced by $\mathrm{ZnO}$ under ultrasonication. $\mathrm{ZnO} / \mathrm{CdS}$ hierarchical nanofibers with optimal composition could completely remove BPA within $30 \mathrm{~min}$, with a rate of $0.1557 \mathrm{~min}^{-1}$, many-fold improved compared to the sole photocatalytic effect [82]. Among titanate piezoelectric photocatalysts, $\mathrm{SrTiO}_{3}$ inverse opal doped with rhodium was found to give visible-light-driven degradation of BPA under ultrasonic vibration. The 3D ordered inverse opal structure obtained by a hard template method, along with $0.5 \%$ Rh doping, contributed to light harvesting, so that almost complete removal of BPA was attained in $30 \mathrm{~min}$ [83]. Mixed titanates were also investigated, e.g., $\mathrm{Na}_{0.5} \mathrm{Bi}_{0.5} \mathrm{TiO}_{3}$ nanowires, synthesized by an efficient templated hydrothermal method, starting from $\mathrm{Na}_{2} \mathrm{Ti}_{3} \mathrm{O}_{7}$ template nanowires subjected to ion-exchange with $\mathrm{Bi}^{3+}$ [84]. The piezocatalytic activity of these nanomaterials was tested in the degradation of several organic pollutants, including BPA, tetracycline hydrochloride, phenol, and common dyes.

\subsubsection{Phthalates}

The removal of various phthalates was investigated principally by means of photocatalytic processes. Jing et al. [85] studied the activity of $\mathrm{TiO}_{2}$ prepared by sol-gel against dimethyl phthalate (DMP). The photodegradation occurred at the surface of the $\mathrm{TiO}_{2}$ particles according to Langmuir-Hinshelwood model and the adsorption constant determined from the dark adsorption was lower than the one obtained in light condition. In particular, under the irradiation of UV light, a synergistic mechanism of adsorption and photocatalysis allowed for the DMP degradation, where $\bullet \mathrm{OH}$ radicals were the primarily responsible species. By adding foreign $\mathrm{Cu}^{2+}$, the $\bullet \mathrm{OH}$ radicals were generated by electrons rather than holes. The highest removal rate of $80.5 \%$ was obtained at $\mathrm{pH} 6-7$ after $75 \mathrm{~min}$ of irradiation time. Wang et al. [86] investigated the photolysis and photocatalysis of typical phthalic acid esters (dimethyl phthalate, DMP; diethyl phthalate, DEP; dibutyl phthalate, $\mathrm{DBP}$ ) comparing $\mathrm{UV}, \mathrm{UV} / \mathrm{TiO}_{2}$, and $\mathrm{UV}-\mathrm{Vis} / \mathrm{Bi}_{2} \mathrm{WO}_{6}$ systems. Both photolysis and photodegradation reaction were performed for $300 \mathrm{~min}$ and the different abilities to remove DMP, DEP, and DBP were estimated. The $\mathrm{UV} / \mathrm{TiO}_{2}$ system showed the highest degradation capability, with removal efficiencies of up to $93 \%$ in $90 \mathrm{~min}$. On the contrary, the performance of UV-Vis $/ \mathrm{Bi}_{2} \mathrm{WO}_{6}$ was not satisfactory in the removal of DMP and DEP. However, $\mathrm{UV}, \mathrm{UV} / \mathrm{TiO}_{2}$, and $\mathrm{UV}-\mathrm{Vis} / \mathrm{Bi}_{2} \mathrm{WO}_{6}$ had a strong ability to degrade DBP. The chemical analysis showed that: (i) UV photolysis attacked the carbon branch and produced o-hydroxybenzoates, (ii) the hydroxyl radicals attacked both the carbon branch and the benzene ring. In the case of photocatalytic systems, hydroxylated compounds and ring-opening byproducts were detected. However, $\mathrm{UV} / \mathrm{TiO}_{2}$ system reacted with the pollutants via hydroxyl radicals, whereas $\mathrm{UV}-\mathrm{Vis} / \mathrm{Bi}_{2} \mathrm{WO}_{6}$ exerted a direct hole oxidation. You et al. [87] prepared via hydrothermal method $\mathrm{Bi}_{2} \mathrm{O}_{3}-\mathrm{TiO}_{2}$ composite for the removal of $\mathrm{Pb}(\mathrm{II})$ and refractory organic DBP from wastewater under visible-light irradiation. The high efficiency of the photocatalyst was due to the presence of various locations on the composite, which allowed the occurrence of the refractory organic oxidation and heavy metal reduction separately. After $4 \mathrm{~h}$ of visible-light irradiation, $\mathrm{Bi}_{2} \mathrm{O}_{3}-\mathrm{TiO}_{2}$ composite could 
effectively perform $40 \%-\mathrm{Pb}$ (II) reduction and $45 \%$-DBP oxidation. Particularly, $\mathrm{Pb}$ (II) could be reduced to $\mathrm{Pb}(0)$ on the $\mathrm{Bi}_{2} \mathrm{O}_{3}-\mathrm{TiO}_{2}$ composite in visible light, because of the energy level adjustment caused by Fermi levels matching at the $n-p$ heterojunction. Additionally, the presence of DBP in the analyzed water sample significantly increased the removal of $\mathrm{Pb}(\mathrm{II})$, highlighting that the coupling of the reduction of heavy metals and the oxidation of organics could efficiently enhance the photocatalytic activity of the system.

Meenakshi et al. [88] synthetized through the sol-gel methodology nanorod $\mathrm{ZnO} / \mathrm{SiC}$ nanocomposite for the UV and visible light photocatalytic degradation of DEP and other toxic organic compounds. The as-prepared materials showed a high degree of porosity, crystallinity, and roughness, and exhibited absorption in the visible light region. A catalyst dosage of $0.5-1.0 \mathrm{mg} / \mathrm{mL}$ allowed for $90 \%$ DEP degradation at neutral $\mathrm{pH}$ conditions under UV and visible-light irradiations. Finally, the nanorod $\mathrm{ZnO} / \mathrm{SiC}$ nanocomposite could be reused up to three cycles without losing its activity and always following pseudo first-order kinetics. Li et al. [89] prepared a dual Z-scheme heterostructure photocatalyst, composed by mesoporous graphitic carbon nitride $\left(m p g-C_{3} N_{4}\right)$, BiOBr, polythiophene (PTh), and magnetic iron oxide, for the photocatalytic degradation of DMP in water under visible light. The reaction rate constant was 3.7- and 4.5-fold higher than those of pristine $\mathrm{g}-\mathrm{C}_{3} \mathrm{~N}_{4}$ and $\mathrm{BiOBr}$, respectively. The photocatalytic DMP degradation efficiency of mpg- $\mathrm{C}_{3} \mathrm{~N}_{4} / \mathrm{BiOBr} / \mathrm{PTh}$ was $40 \%$ and $50 \%$ higher than that of pristine $\mathrm{g}-\mathrm{C}_{3} \mathrm{~N}_{4}$ and $\mathrm{BiOBr}$, respectively. The enhanced visible-light photocatalytic performance, which followed a pseudo first-order kinetic, was attributed to the dual Z-scheme heterostructure generated between mpg- $\mathrm{C}_{3} \mathrm{~N}_{4}$, PTh, and BiOBr. The chemical investigation revealed that the active species $\mathrm{h}^{+}, \bullet \mathrm{O}_{2}{ }^{-}$, and $\bullet \mathrm{OH}$ coexisted during the photocatalytic reaction process, and that $\mathrm{h}^{+}$exerted the main role in the destruction of DMP species (Figure 8).

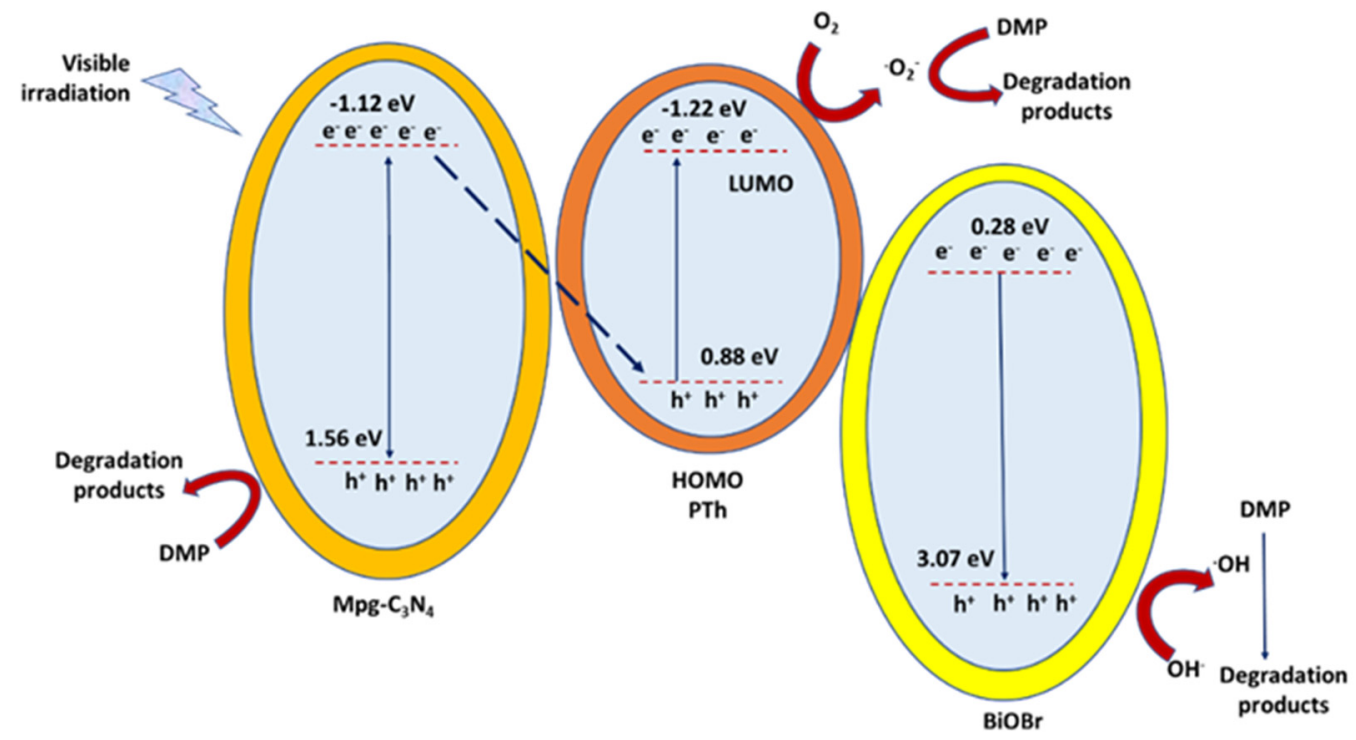

Figure 8. The schematic mechanism for DMP photocatalytic degradation over $m p g-C_{3} N_{4} / \mathrm{BiOBr} / \mathrm{PTh}$ (polythiophene) heterostructure under visible-light irradiation, as described into [89].

Studies on non-irradiated removal of PAEs relied mainly on sulfate-mediated processes. Dong et al. [90] performed the degradation of several phthalates in marine sediments by sodium persulfate $\left(\mathrm{Na}_{2} \mathrm{~S}_{2} \mathrm{O}_{8}, \mathrm{PS}\right)$ activated by a series of iron-cerium (Fe-Ce) bimetallic catalysts (FCBCs). With a Fe-Ce molar ratio of 1.5:1 the degradation of DMP, DEP, di2-ethylhexyl phthalate, dioctyl phthalate and diisononyl phthalate showed the highest value over FCBC and an increase of $\mathrm{Ce}$ amount resulted in an improvement in oxygen storage capacity and catalytic activity of bimetallic catalysts. The $\mathrm{Fe}^{3+} / \mathrm{Fe}^{2+}$ and $\mathrm{Ce}^{4+} / \mathrm{Ce}^{3+}$ redox couples exerted a synergistic catalytic effect in addition to electron transfer of oxygen vacancies, activated $\mathrm{S}_{2} \mathrm{O}_{8}{ }^{2-}$ to release $\bullet \mathrm{SO}_{4}{ }^{-}$and $\bullet \mathrm{OH}$ radicals, which were crucial in the oxidative degradation process of PAEs. When the PS and FCBC concentrations were 
$1.0 \times 10^{-5} \mathrm{M}$ and $1.67 \mathrm{~g} / \mathrm{L}$, respectively, the PAE degradation achieved a maximum of $86 \%$ at $\mathrm{pH} 2$ and rate constant of $1.5 \times 10^{-1} \mathrm{~h}^{-1}$. The activation of persulfate was reported also using some metal-organic frameworks (MOFs). Ding et al. [91] investigated the adsorptive and catalytic properties of a Fe-based MOF (Fe-MOF-74) for the removal of DMP in water. The adsorption behaviors were evaluated by the Freundlich and pseudo-second-order model. The selective adsorption was crucial in combination with molecular imprinting technique to obtain a 1.5-fold increase in catalytic rate. In particular, DMP was firstly adsorbed on the surface of the material by physical interactions and then $\mathrm{SO}_{4} \bullet-$ and $\bullet \mathrm{OH}$ radicals, generated from PS activation, catalytically oxidized DMP with a degradation rate in water of around $90 \%$ after $30 \mathrm{~min}$.

The main outcomes reported in this section highlight that the most representative photocatalysts and catalysts used for the degradation of plastic components are hybrid and/or composite nanomaterials prepared by wet-chemical routes (i.e., sol-gel, hydrothermal or mixed) and composed by metal oxides, $\mathrm{M}_{\mathrm{y}} \mathrm{O}_{\mathrm{x}}$, in which $\mathrm{M}=\mathrm{Ti}, \mathrm{Zn}$, Fe and $\mathrm{W}$ are the principal species. High levels of removal were obtained by using visible light and, in some cases, solar irradiation. The chief features and performances of these nanomaterials are summarized in Table 2, including the best achieved removal efficiencies and corresponding rate constants.

Table 2. Summary of representative metal-oxide-based nanomaterials used for the degradation processes of bisphenols and phthalates.

\begin{tabular}{|c|c|c|c|c|c|}
\hline Material & Preparation & Target & Conditions & Results & Ref. \\
\hline$(\mathrm{N}, \mathrm{Co})$-codoped $\mathrm{TiO}_{2}$ & $\begin{array}{l}\text { Wet impregnation } \\
\text { method }\end{array}$ & $\begin{array}{c}\mathrm{BPA} \\
(20 \mathrm{mg} / \mathrm{L})\end{array}$ & $\begin{array}{l}\text { Visible-light } \\
\text { irradiation }\end{array}$ & $\begin{array}{l}97 \% \text { removal, } \\
0.0195 \mathrm{~min}^{-1}\end{array}$ & [69] \\
\hline $\begin{array}{c}\mathrm{TiO}_{2-x} / \text { rGO } \\
\text { nanocomposite }\end{array}$ & $\begin{array}{l}\text { Hydrothermal- } \\
\text { calcination } \\
\text { method }\end{array}$ & $\begin{array}{c}\mathrm{BPA} \\
(2.5 \mathrm{mg} / \mathrm{L})\end{array}$ & $\begin{array}{l}\text { Visible-light } \\
\text { irradiation } \\
(60 \mathrm{~min})\end{array}$ & $\begin{array}{l}91 \% \text { removal, } \\
0.049 \mathrm{~min}^{-1}\end{array}$ & {$[66]$} \\
\hline $\begin{array}{l}\mathrm{TiO}_{2} @ \mathrm{ACD} @ \mathrm{RGO} \\
\text { composite }\end{array}$ & $\begin{array}{l}\text { Photochemical } \\
\text { method }\end{array}$ & $\begin{array}{c}\mathrm{BPA} \\
(20 \mathrm{mg} / \mathrm{L})\end{array}$ & $\begin{array}{l}\text { UV irradiation } \\
\text { (60 min) }\end{array}$ & $\begin{array}{c}85.6 \% \mathrm{removal}, \\
0.739 \mathrm{mg} / \mathrm{L} \cdot \mathrm{min}\end{array}$ & [67] \\
\hline $\mathrm{Fe}_{3} \mathrm{O}_{4} @ \mathrm{mTiO}_{2} / \mathrm{C}$ & $\begin{array}{c}\text { Sol-gel } \\
\text { Methodology }\end{array}$ & $\mathrm{BPA}$ & $\begin{array}{l}\text { Visible-light } \\
\text { irradiation } \\
\text { (120 min) }\end{array}$ & $\begin{array}{l}100 \% \text { removal, } \\
0.01045 \mathrm{~min}^{-1}\end{array}$ & [70] \\
\hline $\begin{array}{c}\mathrm{Ag} / \mathrm{Fe}, \mathrm{N}- \\
\mathrm{TiO}_{2} / \mathrm{Fe}_{3} \mathrm{O}_{4} @ \mathrm{SiO}_{2} \\
(\mathrm{AgFeNTFS})\end{array}$ & $\begin{array}{c}\text { Sol-gel } \\
\text { Methodology }\end{array}$ & $\begin{array}{c}\text { BPA }(2 \mathrm{mg} / \mathrm{L}), \\
\text { E. coli }\left(10^{6} \mathrm{CFU} / \mathrm{mL}\right),\end{array}$ & $\begin{array}{l}\text { Visible-light } \\
\text { irradiation } \\
\text { (360 min for BPA, } \\
90 \text { min for E. coli) }\end{array}$ & $100 \%$ removal & [71] \\
\hline $\begin{array}{c}\left(\mathrm{g}-\mathrm{C}_{3} \mathrm{~N}_{4}\right)-\mathrm{CaTiO}_{3} \\
\text { heterojunction }\end{array}$ & $\begin{array}{l}\text { Mixing } \\
\text { methodology }\end{array}$ & BPA & $\begin{array}{l}\text { Sunlight irradiation } \\
(120 \mathrm{~min})\end{array}$ & $47 \%$ removal & [73] \\
\hline C60@AgCl-ZnAl LDO & $\begin{array}{c}\text { Sol-gel } \\
\text { Methodology }\end{array}$ & $\begin{array}{c}\mathrm{BPA} \\
(0.5 \mathrm{~g} / \mathrm{L})\end{array}$ & $\begin{array}{l}\text { Ultraviolet light } \\
\qquad(5 \mathrm{~min})\end{array}$ & $100 \%$ removal & {$[72]$} \\
\hline $\begin{array}{c}\mathrm{Gd}_{2} \mathrm{WO}_{6} / \mathrm{ZnO} / \text { bentonite } \\
(\mathrm{GWZB}) \\
\text { nanocomposite }\end{array}$ & $\begin{array}{l}\text { Hydrothermal } \\
\text { process }\end{array}$ & $\begin{array}{l}\text { Ciprofloxacin }(\mathrm{CF}) \\
\left(4 \times 10^{-5} \mathrm{M}\right), \mathrm{BPA} \\
\left(4 \times 10^{-5} \mathrm{M}\right)\end{array}$ & $\begin{array}{l}\text { Visible-light } \\
\text { irradiation }\end{array}$ & $\begin{array}{c}\text { Removal } 98.3 \% \\
\text { and } 97.9 \% \\
\text { respectively }\end{array}$ & [79] \\
\hline $\begin{array}{c}\mathrm{MnFe}_{2} \mathrm{O}_{4} / \mathrm{MX} \\
\text { magnetic composites }\end{array}$ & $\begin{array}{c}\text { Sol-gel } \\
\text { Methodology }\end{array}$ & $\begin{array}{l}\text { BPA }(10 \mathrm{mg} / \mathrm{L}), \\
\text { sulfadiazine } \\
(10 \mathrm{mg} / \mathrm{L}), \\
\text { ciprofloxacin } \\
(10 \mathrm{mg} / \mathrm{L})\end{array}$ & PMS activation & $\begin{array}{l}\text { Removal of } 95 \%, \\
91 \% \text { and } 85 \% \\
\text { respectively }\end{array}$ & {$[80]$} \\
\hline
\end{tabular}


Table 2. Cont.

\begin{tabular}{|c|c|c|c|c|c|}
\hline Material & Preparation & Target & Conditions & Results & Ref. \\
\hline Fe-doped $\mathrm{TiO}_{2} / \mathrm{rGO}$ & $\begin{array}{l}\text { Hydrothermal } \\
\text { process }\end{array}$ & $\begin{array}{c}\text { BPA, } \\
\text { Bisphenol F (BPF), } \\
\text { Bisphenol AF (BPAF), } \\
\text { Bisphenol S (BPS) } \\
(20 \mathrm{mg} / \mathrm{L})\end{array}$ & $\begin{array}{c}\text { Visible-light } \\
\text { irradiation } \\
\text { (60 min for BPA, } \\
120 \text { min for BPF, BPAF } \\
\text { and BPS) }\end{array}$ & $\begin{array}{c}\text { Removal of } 100 \% \text {, } \\
100 \%, 100 \% \text { and } \\
96 \% \text { respectively }\end{array}$ & [68] \\
\hline $\begin{array}{c}\mathrm{Bi}_{2} \mathrm{WO}_{6} / \mathrm{BiOI} \\
\text { (BWOI-3 morphology) }\end{array}$ & $\begin{array}{l}\text { Microwave- } \\
\text { assisted synthetic } \\
\text { method }\end{array}$ & $\begin{array}{c}\text { Methyl orange (MO), } \\
\text { BPA }\end{array}$ & $\begin{array}{c}\text { Visible-light } \\
\text { irradiation } \\
\text { (60 min for } \mathrm{MO}, \\
100 \text { min for BPA) }\end{array}$ & $\begin{array}{c}\text { Removal } 95.0 \% \\
\text { and } 86.8 \% \\
\text { respectively, } \mathrm{MO}: \\
0.04169 \mathrm{~min}^{-1} \\
\text { BPA: } 0.01778 \mathrm{~min}^{-1}\end{array}$ & [75] \\
\hline $\begin{array}{l}\text { Polythiophene } \\
\text { (PTh)/ } \mathrm{Bi}_{4} \mathrm{O}_{5} \mathrm{I}_{2}\end{array}$ & $\begin{array}{c}\text { Sol-gel } \\
\text { Methodology }\end{array}$ & BPA & $\begin{array}{l}\text { Visible-light } \\
\text { irradiation } \\
(30 \mathrm{~min})\end{array}$ & $\begin{array}{l}\text { Removal } 99.2 \% \text {, } \\
0.194 \mathrm{~min}^{-1}\end{array}$ & [74] \\
\hline $\begin{array}{l}\mathrm{Pd} / \mathrm{PdO} / \beta-\mathrm{Bi}_{2} \mathrm{O}_{3} \\
\text { composite }\end{array}$ & $\begin{array}{l}\text { Simple two-step } \\
\text { Sol-gel-based } \\
\text { process }\end{array}$ & BPA & $\begin{array}{l}\text { Visible-light } \\
\text { irradiation } \\
(30 \mathrm{~min})\end{array}$ & $\begin{array}{l}\text { Removal of } 97.4 \%, \\
0.1129 \mathrm{~min}^{-1}\end{array}$ & [76] \\
\hline $\mathrm{Pd} / \mathrm{Bi}_{4} \mathrm{O}_{5} \mathrm{Br}_{2}$ & $\begin{array}{l}\text { Solvothermal- } \\
\text { reduction } \\
\text { method }\end{array}$ & $\begin{array}{c}\mathrm{BPA} \\
(20 \mathrm{mg} / \mathrm{L})\end{array}$ & $\begin{array}{l}\text { LED visible-light } \\
\text { irradiation } \\
(70 \mathrm{~min})\end{array}$ & $\begin{array}{l}95.8 \% \text { removal, } \\
0.0548 \mathrm{~min}^{-1}\end{array}$ & [77] \\
\hline Nano flake $\mathrm{Ag}_{3} \mathrm{PO}_{4}$ & $\begin{array}{c}\text { Sol-gel } \\
\text { Methodology }\end{array}$ & $\begin{array}{c}\mathrm{BPA} \\
(15 \mathrm{mg} / \mathrm{L})\end{array}$ & $\begin{array}{l}\text { Visible-light } \\
\text { irradiation } \\
(30 \mathrm{~min})\end{array}$ & $\begin{array}{c}100 \% \text { removal } \\
\text { efficiency, } \\
0.6324 \text { min }^{-1}\end{array}$ & [78] \\
\hline $\mathrm{Cu}_{2} \mathrm{O} @ \beta-\mathrm{CD}$ & $\begin{array}{l}\text { Topotaxial } \\
\text { conversion }\end{array}$ & $\begin{array}{c}\mathrm{BPA} \\
(8 \mathrm{mg} / \mathrm{L})\end{array}$ & Neutral pH & $\begin{array}{c}83.7 \% \text { removal, } \\
0.0196 \mathrm{~min}^{-1}\end{array}$ & [81] \\
\hline $\mathrm{TiO}_{2}$ & $\begin{array}{c}\text { Sol-gel } \\
\text { Methodology }\end{array}$ & $\begin{array}{c}\mathrm{DMP} \\
(5.16 \mu \mathrm{M})\end{array}$ & $\begin{array}{c}\text { UV irradiation } \\
\text { (75 min) and } \mathrm{pH} 6-7\end{array}$ & $\begin{array}{l}80.5 \% \text { removal, } \\
0.0768 \mathrm{~min}^{-1}\end{array}$ & [85] \\
\hline $\mathrm{TiO}_{2}$ & $\begin{array}{c}\text { Sol-gel } \\
\text { Methodology }\end{array}$ & $\begin{array}{c}\text { DMP, DEP, DBP } \\
(6,6, \text { and } 4.128 \mathrm{mg} / \mathrm{L})\end{array}$ & $\begin{array}{l}\text { UV irradiation } \\
\qquad(90 \mathrm{~min})\end{array}$ & $\begin{array}{c}\text { Removal 93.0, 92.6, } \\
92.5 \% \text { respectively, } \\
0.025 \mathrm{~min}^{-1}\end{array}$ & [86] \\
\hline $\mathrm{Bi}_{2} \mathrm{O}_{3}-\mathrm{TiO}_{2}$ composite & $\begin{array}{l}\text { Hydrothermal } \\
\text { process }\end{array}$ & $\mathrm{Pb}(\mathrm{II}), \mathrm{DBP}$ & $\begin{array}{l}\text { Visible-light } \\
\text { irradiation } \\
\quad(4 \mathrm{~h})\end{array}$ & $\begin{array}{l}45 \%-\mathrm{DBP} \\
\text { oxidation, } \\
40 \%-\mathrm{Pb}(\mathrm{II}) \\
\text { reduction }\end{array}$ & [87] \\
\hline $\begin{array}{l}\text { Nanorod } \mathrm{ZnO} / \mathrm{SiC} \\
\text { nanocomposite }\end{array}$ & $\begin{array}{c}\text { Sol-gel } \\
\text { Methodology }\end{array}$ & $\begin{array}{c}\text { DEP } \\
(5 \mathrm{ppm})\end{array}$ & $\begin{array}{l}\text { UV and visible light, } \\
\text { neutral pH }\end{array}$ & $\begin{array}{c}90 \% \text { removal, UV: } \\
46.86 \times 10^{-3} \min ^{-1}, \\
\text { Visible: } \\
8.52 \times 10^{-3} \mathrm{~min}^{-1} .\end{array}$ & [88] \\
\hline $\begin{array}{c}\text { mpg- } \\
\mathrm{C}_{3} \mathrm{~N}_{4} / \mathrm{BiOBr} / \mathrm{PTh}(\mathrm{Z}- \\
\text { scheme })\end{array}$ & $\begin{array}{c}\text { Sol-gel } \\
\text { Methodology }\end{array}$ & $\begin{array}{c}\text { DMP } \\
(1 \mathrm{~g} / \mathrm{L})\end{array}$ & $\begin{array}{l}\text { Visible-light } \\
\text { irradiation }\end{array}$ & $\begin{array}{c}\text { Removal efficiency } \\
\text { of } 40 \% \text { and } 50 \% \\
\text { higher than } \\
\text { g- } \mathrm{C}_{3} \mathrm{~N}_{4} \text { and } \mathrm{BiOBr} \text {, } \\
0.193 \mathrm{~h}^{-1} \text {. }\end{array}$ & [89] \\
\hline $\begin{array}{l}\text { Iron-cerium (Fe-Ce) } \\
\text { bimetallic catalysts } \\
\text { (FCBCs) }\end{array}$ & $\begin{array}{c}\text { Sol-gel } \\
\text { Methodology }\end{array}$ & $\begin{array}{l}\text { PAEs (DMP, DEP, } \\
\text { DEHP, DINP, } \\
\text { DnOP, DIDP) }\end{array}$ & $\begin{array}{c}\text { PS } 1.0 \times 10^{-5} \mathrm{M} \\
\text { FCBC } 1.67 \mathrm{~g} / \mathrm{L}, \mathrm{pH} 2\end{array}$ & $\begin{array}{r}86 \% \text { removal, } \\
1.5 \times 10^{-1} \mathrm{~h}^{-1}\end{array}$ & [90] \\
\hline
\end{tabular}

\subsection{Photocatalytic and Catalytic Degradation of Agricultural Chemicals}

Agricultural chemicals (or agrochemicals) are a variety of synthetic compounds used to protect crops and increase their yield and quality, including mainly pesticides (herbicides, insecticides, fungicides, nematicides, and so forth), but also fertilizers, soil conditioners, and plant growth regulators (Figure 9). Pesticides are meant to eradicate plants, animals, fungi, and microorganisms that are detrimental to cultures, affecting selected functions 
in target organisms. Nonetheless, they can also exert toxicity toward humans and wild fauna. The evaluation of these effects is complex, as most toxicity tests are performed in acute rather than long-term experiments, while endocrine disrupting activity often arises upon long-term exposure [25]. The growth of the world's population increases the demand for farming land and productivity, hence the usage of agrochemicals. According to the Food and Agriculture Organization of the United Nations (FAO) the global production of pesticides exceeds 4 million tons per year [92]. These can easily be transferred from soil to surface waters and groundwater and encounter living beings, causing adverse effects. Therefore, pesticides represent a chronic and widespread threat to humans and the ecosystem and their removal from water is a severe concern.

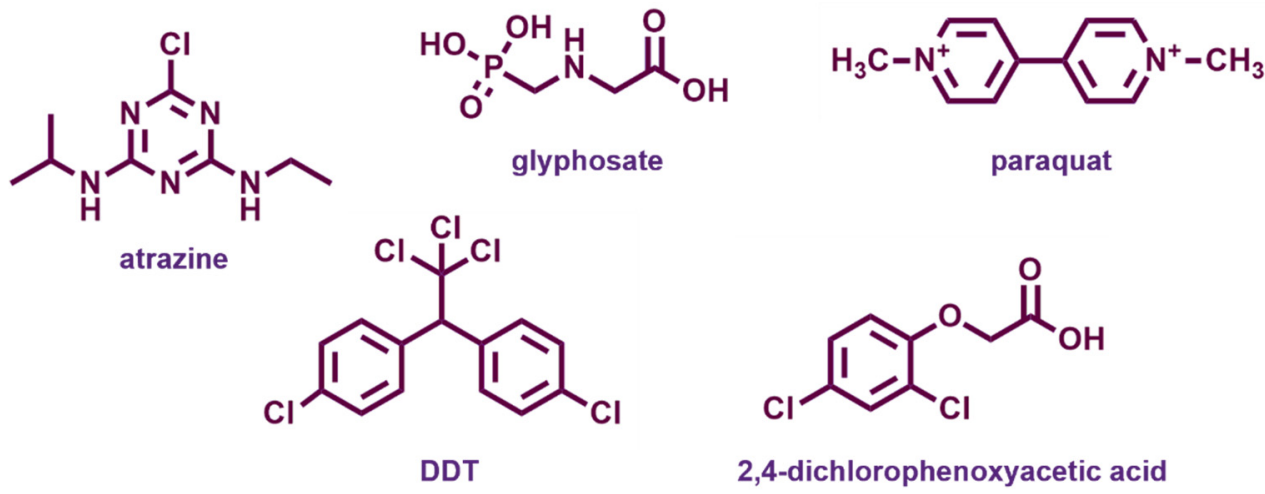

Figure 9. Chemical structures of the most widespread agrochemicals with endocrine disrupting properties.

\subsubsection{Atrazine}

Atrazine (ATZ) is a chlorinated triazine used as herbicide in the control of broadleaf and grassy weeds, particularly applied in corn cultivation. The triazine ring structure gives high chemical stability and a very long half-life in water, so it can be easily transported through surface water and soil and enter the food chain, becoming a potential threat to human health and animals, connected with reproductive abnormalities and potential carcinogenity. Atrazine has been banned in the European Union since 2004 and has been listed as a prior harmful substance by the U.S. EPA and the Ministry of Ecology and Environment of China. A large number of works have dealt with the removal of this herbicide from water [93].

Noticeable performances in the visible light-driven degradation of atrazine were obtained by coupling two strategies for the modification of $\mathrm{TiO}_{2}$ : co-doping with indium and sulfur and the formation of a heterostructure with $\mathrm{rGO}$ [94]. The In,S-TiO $@_{2} \mathrm{rGO}$ nanocomposites were synthesized by an ultrasonic-assisted solvothermal method and the optimized composition yielded complete degradation and 95.5\% mineralization of $20 \mathrm{mg} / \mathrm{L}$ ATZ within $20 \mathrm{~min}$ and good stability with reuse. Titanate semiconductors with peroskite structure are promising photocatalytic materials. Shawky et al. prepared $\mathrm{LaTiO}_{3}$ nanowires modified through the photo-assisted deposition of $\mathrm{Ag}$, which resulted in an improvement of surface texture, light absorption in the visible range, and a reduction of the electron-hole recombination [95]. The $\mathrm{Ag} / \mathrm{LaTiO}_{3}$ nanowires (2.5 wt $\%$ optimal Ag load) could photodegrade ATZ (50 mg/L initial concentration) under visible light after just $40 \mathrm{~min}$ at a catalyst dosage of $1.2 \mathrm{~g} \mathrm{~L}^{-1}$. Additionally, the same authors synthetized novel spinel-structured $\mathrm{NiCO}_{2} \mathrm{O}_{4}$ nanorods that worked as a visible light photocatalyst upon $\mathrm{Ag}$ loading [96]. Particularly, $5 \mathrm{wt} \%$ loading of Ag improved the optical and optoelectronic properties of the photocatalyst, resulting in the minimization of the bandgap from 3.6 down to $2.57 \mathrm{eV}$ and in the enhancement of visible light absorption. The $\mathrm{Ag} / \mathrm{NiCo}_{2} \mathrm{O}_{4}$ nanorods exhibited a boosted photodegradation of ATZ to completion within $20 \mathrm{~min}$ at $2.0 \mathrm{~g} \mathrm{~L}^{-1}$ dosage, with excellent recyclability. Furthermore, in this case, Ag-loaded photocatalyst showed lower electron-hole recombination and outperformed the pristine sample. 
Majhi et al. developed though a one-step hydrothermal method bismuth-based ternary heterostructures, $\mathrm{CdS} / \mathrm{BiOBr} / \mathrm{Bi}_{2} \mathrm{O}_{2} \mathrm{CO}_{3}$, with a controlled morphology and improved visible light absorption [97]. The materials consisted of well dispersed CdS nanoparticles (50-80 nm) anchored over ultrathin $\mathrm{BiOBr}$ and $\mathrm{Bi}_{2} \mathrm{O}_{2} \mathrm{CO}_{3}$ nanoplates, which guaranteed a high interfacial contact. The photocatalyst showed significant degradation efficiency $(>95 \%$ in $30 \mathrm{~min}$ ) of ATZ herbicide and reduced the cytotoxicity of the treated water solution. Scavenger and radical $\left(\bullet \mathrm{OH}\right.$ and $\left.\bullet \mathrm{O}_{2}{ }^{-}\right)$trapping experiments highlighted that the photocatalytic degradation occurred by a double Z-scheme electron transfer mechanism.

The combination of heterogeneous Fenton and photocatalysis was investigated by Yang et al. with a Fe/ $\mathrm{TiO}_{2}$ sol-gel material [98]. Using $1 \mathrm{~g} / \mathrm{L}$ of catalyst, $1.6 \mathrm{mM} \mathrm{H}_{2} \mathrm{O}_{2}$ and visible light, $95 \%$ degradation of atrazine $(10 \mathrm{mg} / \mathrm{L}$ initial concentration) was accomplished in $30 \mathrm{~min}$ at $\mathrm{pH} \mathrm{3}$, and more than $75 \%$ degradation was achieved at up to $\mathrm{pH} 7$. Several intermediate and final products were identified, and the possible degradation mechanism was inferred. Recently, in the field of sulfate-based AOPs, sulfite was proposed as an alternative to the common precursors of sulfate radical. Its activation on zinc-copper ferrites was demonstrated under irradiation by Huang et al. [99]. The $\mathrm{Zn}_{x} \mathrm{Cu}_{1-\mathrm{x}} \mathrm{Fe}_{2} \mathrm{O}_{4}$ mixed oxides, synthesized by a sol-gel combustion method, showed magnetic properties and excellent ability in the removal of ATZ under UV-visible irradiation with the stepwise addition of $\mathrm{Na}_{2} \mathrm{SO}_{3} . \mathrm{Zn}_{0.8} \mathrm{Cu}_{0.2} \mathrm{Fe}_{2} \mathrm{O}_{4}$ gave the highest activity within 30 min and $\mathrm{SO}_{4} \bullet-$ was identified as the main reactive species. Moreover, the catalysts could be magnetically separated from the solution for its reuse. The influence of several process parameters was assessed, and a possible reaction pathway was illustrated.

Photoelectrocatalytic systems were also proposed for the degradation of agrochemicals. For example, Xie et al. examined the mechanism of photoelectrochemical removal of ATZ, using typical $\mathrm{TiO}_{2}$ nanotube arrays obtained by anodization on Ti plates as working photoanode and a wide spectrum Xe lamp [100]. The best removal efficiency reached $96.8 \%$ at applied potential of $0.2 \mathrm{~V}$ vs. SCE in $2 \mathrm{~h}$, with reaction rate constant of $1.72 \mathrm{~h}^{-1}$. The results indicated that the of optimal bias (requesting a low electric power input) did not change the degradation products of atrazine, but it enhanced the removal rate by affecting the amount and distribution of the ROS generated. Among them, the superoxide radical seemed to play a central role in ATZ dechlorination, possibly because of its nucleophilicity.

The intimate coupling of photocatalysis and biodegradation (ICPB) approach is promising for the treatment of emerging contaminants. A valuable example was reported by Zhang et al., who prepared a heterostructure of $\mathrm{Bi}_{2} \mathrm{WO}_{6}$ with carbon nitride by hydrothermal method and coated it on a polyurethane sponge cube via powder spraying [101]. A biofilm derived from active sludge was then cultivated in the inner of the macroporous sponge carrier. Under UV-visible light, the $\mathrm{Bi}_{2} \mathrm{WO}_{6} / \mathrm{C}_{3} \mathrm{~N}_{4}$ heterojunction decomposed atrazine into biodegradable intermediates, which were successively mineralized by the microorganisms, increasing the removal of $20 \%$ (up to $50 \%$ in $8 \mathrm{~h}$ with $20 \mathrm{mg} / \mathrm{L}$ initial ATZ concentration).

Technologies independent from light irradiation, especially sulfate-based AOPs, are increasingly studied for the decomposition of EDCs. For instance, the activation of persulfate was tested for the removal of atrazine using $\mathrm{Fe}_{3} \mathrm{O}_{4}$ nanoparticles supported on sepiolite, a hydrated magnesium silicate clay [102]. Magnetite NPs were synthesized in situ and loaded onto fibrous sepiolite via a co-precipitation method. The effective adsorption and alkaline $\mathrm{pH}$ values favoured the removal of ATZ, which reached $71.6 \%$ after $60 \mathrm{~min}$, with $92 \mathrm{mmol} / \mathrm{L}$ of PS and $10 \mathrm{mmol} / \mathrm{L}$ initial pesticide concentration). Although TOC removal was merely $21 \%$ the identified products were nontoxic, and the nanocomposite maintained structural and functional stability during four consecutive batch runs. Turning to PMS, a heterogeneous Fenton-like system was realized coupling it with the addition of hydroxylamine (HA) in the presence of $\mathrm{Fe}_{3} \mathrm{O}_{4}$ [103]. HA had a double role, as PMS activator, which accounted for $40 \%$ of the observed ATZ decomposition, and also as promoter of the $\mathrm{Fe}(\mathrm{III}) / \mathrm{Fe}(\mathrm{II})$ redox cycle on magnetite surface, which additionally generated $\bullet \mathrm{OH}$ radicals. The degradation rate constant of atrazine at near-neutral $\mathrm{pH}$ in $\mathrm{Fe}_{3} \mathrm{O}_{4} / \mathrm{PMS} / \mathrm{HA}$ 
system $\left(0.152 \mathrm{~min}^{-1}\right)$ was almost 5 times higher than that in the homogeneous PMS/HA system. PMS was activated also by $\mathrm{Cu}$-doped $\mathrm{LaFeO}_{3}$ perovskites synthesized through a sol-gel method [104]. The sample with $\mathrm{LaFe}_{0.8} \mathrm{Cu}_{0.2} \mathrm{O}_{3-\delta}$ composition exhibited the highest catalytic activity and stability, completely removing ATZ $(23 \mu \mathrm{M})$ in $60 \mathrm{~min}$, with the use of $0.5 \mathrm{~g} / \mathrm{L}$ catalyst and $0.5 \mathrm{mM}$ PMS. Both $\mathrm{Fe}(\mathrm{III}) / \mathrm{Fe}(\mathrm{II})$ and $\mathrm{Cu}(\mathrm{II}) / \mathrm{Cu}(\mathrm{I})$ cycles along with surface hydroxyl groups contributed to the degradation in a wide $\mathrm{pH}$ range (2-10), leading to different possible reaction pathways. Dong et al. developed a cobalt-nickel mixed oxide supported on diatomite, preparing by co-precipitation $2 \mathrm{D} \mathrm{CoNi}_{3} \mathrm{O}_{4}$ nanoribbons which were vertically aligned on diatomite [105]. The topology of the nanoribbons in the composite comprised abundant exposed edges and sharp corners, working as active sites, and open channels, facilitating the migration and reaction of PMS and pollutant molecules. The $30 \mathrm{wt} \% \mathrm{CoNi}_{3} \mathrm{O}_{4} /$ diatomite/PMS system gave 93\% ATZ (5 ppm) removal and $56 \%$ TOC decrease after $30 \mathrm{~min}$ (rate constant $0.0842 \mathrm{~min}^{-1}$ ), with $0.1 \mathrm{~g} / \mathrm{L}$ of catalyst and $0.3 \mathrm{mM}$ PMS. Comparable results were recorded in real water samples. The detection of the involved radicals evidenced that $\mathrm{SO}_{4} \bullet-$ was the dominant oxidant, while $\bullet \mathrm{O}_{2}{ }^{-}$ contributed to the reversible redox cycle of $\mathrm{Co}^{2+} / \mathrm{Co}^{3+}$ and $\mathrm{Ni}^{2+} / \mathrm{Ni}^{3+}$, supporting the excellent catalytic efficiency.

Among electrocatalytic processes, a Ti/ $\mathrm{PbO}_{2}$ electrode modified with cobalt and samarium was prepared by one-step electrodeposition on pretreated Ti substrates and used as anode for the electrocatalytic removal of ATZ in wastewater [106]. Co and Sm were proved to enhance the catalytic activity and stability, indeed the $\mathrm{Ti} / \mathrm{PbO}_{2}-\mathrm{Co}-\mathrm{Sm}$ electrode displayed higher oxygen evolution potential, lower charge transfer resistance, longer operative lifetime and higher degradation efficiency compared with bare $\mathrm{Ti} / \mathrm{PbO}_{2}$. $92.6 \%$ atrazine removal and $84.5 \%$ COD decrease were achieved in $3 \mathrm{~h}$ under optimized conditions: current density $20 \mathrm{~mA} \mathrm{~cm}^{-2}, \mathrm{pH} 5$, temperature $35^{\circ} \mathrm{C}$. A particularly interesting three-dimensional electrochemical process, i.e., a system composed of 2D electrode with particulate electrode suspension between the two main electrodes, was investigated by $\mathrm{Li}$ et al. [107]. They prepared $\mathrm{CuFe}_{2} \mathrm{O}_{4}$ magnetic nanoparticles by combustion sol-gel method and used them simultaneously as particle electrode and catalyst for PS activation (Figure 10). The best ATZ degradation efficiency (>99\%) and TOC removal (22.1\%) were achieved after $35 \mathrm{~min}$ with solid dosage of $3.0 \mathrm{~g} / \mathrm{L}, 4.0 \mathrm{mM}$ PS, current density of 4 $\mathrm{mA} / \mathrm{cm}^{2}$, and initial $\mathrm{pH}$ 6.3. The nanoparticle electrodes maintained stability throughout five consecutive runs, and sulfate radical was identified as the dominant reactive species in the degradation process.

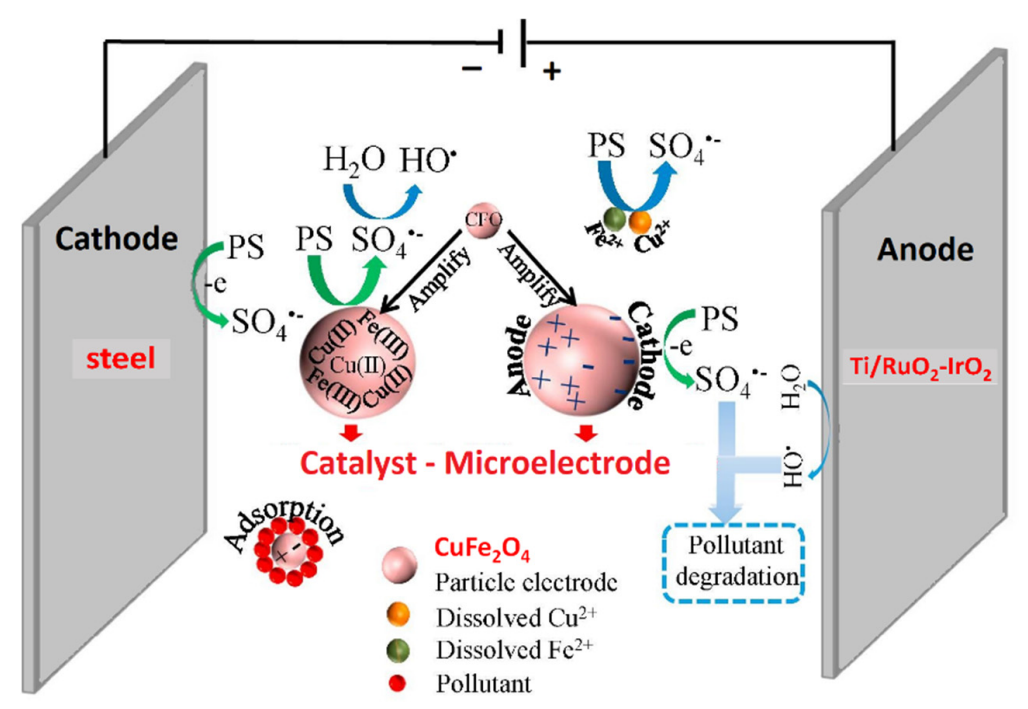

Figure 10. Schematic representation of a 3D electrochemical degradation cell with $\mathrm{CuFe}_{2} \mathrm{O}_{4}(\mathrm{CFO})$ magnetic nanoparticles acting as particle electrodes and catalysts for persulfate (PS) activation. Adapted and reprinted with permission from [107], Copyright (2019) Elsevier. 
The most representative reports concerning agrochemicals as endocrine disruptors are summarized in Table 3, including the principal process conditions and results in terms of removal efficiency and rate constant.

Table 3. Summary of representative metal-oxide-based nanomaterials used for the degradation processes of agricultural chemicals atrazine (ATZ), glyphosate (PMG), paraquat, dichlorodiphenyltrichloroethane (DDT), 2,4-dichlorophenoxyacetic acid (2,4-D) and other pesticides.

\begin{tabular}{|c|c|c|c|c|c|}
\hline Material & Preparation & Target & Conditions & Results & Ref. \\
\hline In,S-TiO ${ }_{2} @ \mathrm{rGO}$ & $\begin{array}{l}\text { ultrasonic-assisted } \\
\text { solvothermal } \\
\text { method }\end{array}$ & $\begin{array}{c}\text { ATZ } \\
(20 \mathrm{mg} / \mathrm{L})\end{array}$ & $\begin{array}{l}\text { Visible light } \\
\text { (20 min) }\end{array}$ & $\begin{array}{c}100 \% \text { removal, } 95.5 \% \\
\text { mineralization, } \\
\mathrm{k}=0.248 \mathrm{~min}^{-1}\end{array}$ & {$[94]$} \\
\hline $\mathrm{Fe}-\mathrm{TiO}_{2}$ & Sol-gel method & $\begin{array}{c}\text { ATZ } \\
(10 \mathrm{mg} / \mathrm{L})\end{array}$ & $\begin{array}{l}\text { Visible light, } \\
1.6 \mathrm{mM} \mathrm{H}_{2} \mathrm{O}_{2} \\
(30 \mathrm{~min})\end{array}$ & $\begin{array}{c}\text { 95\% degradation at } \mathrm{pH} 3 \\
\mathrm{k}=0.1021 \mathrm{~min}^{-1}\end{array}$ & {$[98]$} \\
\hline$\underset{\text { nanowires }}{\mathrm{Ag} / \mathrm{LaTiO}_{3}}$ & $\begin{array}{l}\text { Hydrothermal } \\
\text { method }\end{array}$ & $\begin{array}{c}\mathrm{ATZ} \\
(50 \mathrm{mg} / \mathrm{L})\end{array}$ & $\begin{array}{l}\text { Visible light } \\
\text { (40 min) }\end{array}$ & $\begin{array}{c}100 \% \text { removal } \\
\mathrm{k}=0.0434 \mathrm{~min}^{-1}\end{array}$ & [95] \\
\hline $\begin{array}{l}\mathrm{Ag} / \mathrm{NiCO}_{2} \mathrm{O}_{4} \\
\text { nanorods }\end{array}$ & Co-precipitation & $\begin{array}{c}\mathrm{ATZ} \\
(50 \mathrm{mg} / \mathrm{L})\end{array}$ & $\begin{array}{l}\text { Visible light } \\
\text { (20 min) }\end{array}$ & $\begin{array}{l}100 \% \text { removal, } \\
\mathrm{k}=0.049 \mathrm{~min}^{-1}\end{array}$ & [96] \\
\hline $\mathrm{CdS} / \mathrm{BiOBr} / \mathrm{Bi}_{2} \mathrm{O}_{2} \mathrm{CO}_{3}$ & $\begin{array}{l}\text { Hydrothermal } \\
\text { method }\end{array}$ & $\begin{array}{c}\mathrm{ATZ} \\
(50 \mathrm{mg} / \mathrm{L})\end{array}$ & $\begin{array}{l}\text { Visible light } \\
\text { (30 min) }\end{array}$ & $\begin{array}{l}\text { 95\% removal, } \\
\mathrm{k}=0.122 \mathrm{~min}^{-1}\end{array}$ & [97] \\
\hline $\mathrm{Zn}_{\mathrm{x}} \mathrm{Cu}_{1-\mathrm{x}} \mathrm{Fe}_{2} \mathrm{O}_{4}$ & $\begin{array}{l}\text { Sol-gel } \\
\text { combustion } \\
\text { process }\end{array}$ & $\begin{array}{c}\mathrm{ATZ} \\
(4.4 \mu \mathrm{M})\end{array}$ & $\begin{array}{c}\text { UV-vis light } \\
(30 \text { min), } \\
\mathrm{Na}_{2} \mathrm{SO}_{3} 0.5 \mathrm{mM}\end{array}$ & $\begin{array}{l}95 \% \text { removal, } \\
\mathrm{k}=0.195 \mathrm{~min}^{-1}\end{array}$ & [99] \\
\hline $\mathrm{TiO}_{2}$ nanotubes & $\begin{array}{l}\text { Electrochemical } \\
\text { anodization }\end{array}$ & $\begin{array}{c}\mathrm{ATZ} \\
(2 \mathrm{mg} / \mathrm{L})\end{array}$ & $\begin{array}{l}\text { UV-vis light, } \\
\text { bias } 0.2 \mathrm{~V} \text { vs. SCE }(2 \mathrm{~h})\end{array}$ & $\begin{array}{l}96.8 \% \text { removal, } \\
\mathrm{k}=1.72 \mathrm{~h}^{-1}\end{array}$ & [100] \\
\hline $\mathrm{Bi}_{2} \mathrm{WO}_{6} / \mathrm{C}_{3} \mathrm{~N}_{4}$ & $\begin{array}{l}\text { Hydrothermal } \\
\text { method }\end{array}$ & $\begin{array}{c}\mathrm{ATZ} \\
(20 \mathrm{mg} / \mathrm{L})\end{array}$ & $\begin{array}{l}\text { Visible light, } \\
\text { biofilm }(8 \mathrm{~h})\end{array}$ & $>50 \%$ removal & [101] \\
\hline $\mathrm{Fe}_{3} \mathrm{O}_{4}$-sepiolite & Co-precipitation & $\begin{array}{c}\text { ATZ } \\
(10 \mathrm{mM})\end{array}$ & PS 92 mM (1 h) & $\begin{array}{c}71.6 \% \text { removal, } \\
21 \% \text { mineralization } \\
\mathrm{k}=0.0108 \mathrm{~min}^{-1}\end{array}$ & [102] \\
\hline $\mathrm{Fe}_{3} \mathrm{O}_{4}$ & Commercial & $\begin{array}{c}\text { ATZ } \\
(23 \mu \mathrm{M})\end{array}$ & $\begin{array}{c}\text { PMS } 0.4 \mathrm{mM} \\
\text { hydroxylamine } \\
0.3 \mathrm{mM}(15 \mathrm{~min})\end{array}$ & $\begin{array}{l}100 \% \text { degradation, } \\
\mathrm{k}=0.152 \mathrm{~min}^{-1}\end{array}$ & [103] \\
\hline $\mathrm{Cu}$-doped $\mathrm{LaFeO}_{3}$ & Sol-gel method & $\begin{array}{c}\mathrm{ATZ} \\
(23 \mu \mathrm{M})\end{array}$ & $\begin{array}{l}\text { PMS } 0.5 \mathrm{mM} \\
\quad(1 \mathrm{~h})\end{array}$ & $\begin{array}{c}100 \% \text { degradation, } 52 \% \\
\text { mineralization } \\
\mathrm{k}=0.1406 \mathrm{~min}^{-1}\end{array}$ & [104] \\
\hline $\begin{array}{l}\mathrm{CoNi}_{3} \mathrm{O}_{4} \text { nanorib- } \\
\text { bons/diatomite }\end{array}$ & Co-precipitation & $\begin{array}{c}\text { ATZ } \\
(5 \mathrm{mg} / \mathrm{L})\end{array}$ & $\begin{array}{l}\text { PMS } 0.3 \mathrm{mM} \\
\quad(30 \mathrm{~min})\end{array}$ & $\begin{array}{c}93 \% \text { removal, } \\
56 \% \text { mineralization } \\
\mathrm{k}=0.0842 \mathrm{~min}^{-1}\end{array}$ & [105] \\
\hline $\begin{array}{l}\mathrm{Co}, \mathrm{Sm}-\mathrm{Ti} / \mathrm{PbO}_{2} \\
\text { electrode }\end{array}$ & $\begin{array}{l}\text { Electrochemical } \\
\text { deposition }\end{array}$ & $\begin{array}{c}\mathrm{ATZ} \\
(20 \mathrm{mg} / \mathrm{L})\end{array}$ & $\begin{array}{l}\text { Current density } \\
20 \mathrm{~mA} \mathrm{~cm}^{-2}(3 \mathrm{~h})\end{array}$ & $\begin{array}{c}92.6 \% \text { removal, } \\
\text { 84.5\% COD decrease }\end{array}$ & [106] \\
\hline $\begin{array}{c}\mathrm{Ti} / \mathrm{RuO}_{2}-\mathrm{IrO}_{2} \text { anode, } \\
\mathrm{CuFe}_{2} \mathrm{O}_{4} \text { particles }\end{array}$ & $\begin{array}{l}\text { Sol-gel } \\
\text { combustion } \\
\text { process }\end{array}$ & $\begin{array}{c}\text { ATZ } \\
(46 \mu \mathrm{M})\end{array}$ & $\begin{array}{l}\text { Current density } \\
20 \mathrm{~mA} \mathrm{~cm}^{-2} \\
\text { PS } 4.0 \mathrm{mM}^{\prime} \\
\text { (35 min) }\end{array}$ & $\begin{array}{c}99 \% \text { removal } \\
22.1 \% \text { mineralization } \\
\mathrm{k}=0.0186 \mathrm{~min}^{-1}\end{array}$ & [107] \\
\hline Faceted $\mathrm{TiO}_{2}$ & $\begin{array}{l}\text { Hydrothermal } \\
\text { method }\end{array}$ & $\begin{array}{c}\mathrm{PMG} \\
(10 \mathrm{mg} / \mathrm{L})\end{array}$ & UV light & $\begin{array}{l}100 \% \text { removal in } 50 \mathrm{~min}, \\
\mathrm{k}=3.0 \mathrm{~h}^{-1} \text { on }\{201\}-\mathrm{TiO}_{2}\end{array}$ & [108] \\
\hline $\mathrm{CeO}_{2} \mathrm{NPs}$ & Solution synthesis & $\begin{array}{c}\text { PMG } \\
(25 \mathrm{mg} / \mathrm{L})\end{array}$ & UV or visible light & $\begin{array}{c}100 \% \text { removal in } 5 \mathrm{~min} \\
\left(\mathrm{UV}, \mathrm{k}=0.6601 \mathrm{~min}^{-1}\right) \text { or } \\
20 \mathrm{~min}(\mathrm{visible}, \\
\left.0.3028 \mathrm{~min}^{-1}\right) \text { at } \mathrm{pH} 4\end{array}$ & [109] \\
\hline $\mathrm{W} / \mathrm{ZnO}$ & Precipitation & $\begin{array}{c}\text { PMG } \\
(20 \mathrm{mg} / \mathrm{L}) \\
\end{array}$ & $\begin{array}{l}\text { Simulated solar light } \\
(3 \mathrm{~h})\end{array}$ & $\begin{array}{c}74 \% \text { removal, } \\
30 \% \text { mineralization }\end{array}$ & [110] \\
\hline
\end{tabular}


Table 3. Cont.

\begin{tabular}{|c|c|c|c|c|c|}
\hline Material & Preparation & Target & Conditions & Results & Ref. \\
\hline $\mathrm{BiOBr} / \mathrm{Fe}_{3} \mathrm{O}_{4}$ & $\begin{array}{l}\text { Solvothermal } \\
\text { method }\end{array}$ & $\begin{array}{c}\text { PMG } \\
(100 \mathrm{mg} / \mathrm{L})\end{array}$ & $\begin{array}{l}\text { Visible light } \\
\quad(1 \mathrm{~h})\end{array}$ & $97 \%$ removal & [111] \\
\hline $\mathrm{MoSe}_{2} / \mathrm{BiVO}_{4}$ & $\begin{array}{l}\text { Hydrothermal } \\
\text { method }\end{array}$ & $\begin{array}{c}\text { PMG } \\
\left(10^{-4} \mathrm{M}\right)\end{array}$ & $\begin{array}{l}\text { Visible light } \\
\quad(3 \mathrm{~h})\end{array}$ & $86.1 \%$ removal & [112] \\
\hline $\mathrm{Cu}_{2} \mathrm{~S} / \mathrm{Bi}_{2} \mathrm{WO}_{6}$ & $\begin{array}{l}\text { Hydrothermal } \\
\text { method }\end{array}$ & $\begin{array}{c}\text { PMG } \\
\left(10^{-4} \mathrm{M}\right)\end{array}$ & $\begin{array}{l}\text { Visible light } \\
\quad(3 \mathrm{~h})\end{array}$ & $73.2 \%$ removal & [113] \\
\hline $\mathrm{Fe}_{3} \mathrm{CeO}_{\mathrm{x}}$ & Co-precipitation & $\begin{array}{c}\text { PMG } \\
(100 \mathrm{mg} / \mathrm{L})\end{array}$ & $\begin{array}{l}\text { PMS } 0.5 \mathrm{mM} \\
\quad(15 \mathrm{~min})\end{array}$ & $\begin{array}{c}100 \% \text { removal, } \\
85.6 \mathrm{TOC}_{\text {decrease }} \\
400 \mathrm{mg} \mathrm{L}^{-1} \mathrm{~h}^{-1}\end{array}$ & [114] \\
\hline $\mathrm{TiO}_{2} \mathrm{P} 25$ on $\mathrm{SiC}$ & Dip coating & $\begin{array}{c}\text { Paraquat } \\
(5-40 \mathrm{mg} / \mathrm{L})\end{array}$ & UV-C light & $90 \%$ mineralization & [115] \\
\hline $\mathrm{TiO}_{2}$ on $\mathrm{SBA}-16 \mathrm{SiO}_{2}$ & Sol-gel method & $\begin{array}{l}\text { Paraquat } \\
(50 \mathrm{mg} / \mathrm{L})\end{array}$ & UV light (24 h) & $\begin{array}{c}70 \% \text { removal } \\
\mathrm{k}=0.0431 \mathrm{~min}^{-1}\end{array}$ & [116] \\
\hline $\mathrm{N}-\mathrm{TiO}_{2}$ & $\begin{array}{l}\text { Hydrothermal } \\
\text { method }\end{array}$ & $\begin{array}{l}\text { Paraquat } \\
(20 \mathrm{mg} / \mathrm{L})\end{array}$ & $\begin{array}{l}\text { UV or visible light (120 } \\
\text { min) }\end{array}$ & $\begin{array}{c}\text { Removal 86\% (UV, } \\
\left.\mathrm{k}=0.0230 \mathrm{~min}^{-1}\right), 62 \% \\
\left(\text { visible, } \mathrm{k}=0.0074 \mathrm{~min}^{-1}\right)\end{array}$ & [117] \\
\hline $\begin{array}{c}\mathrm{N}- \\
\mathrm{TiO}_{2} @ \mathrm{SiO}_{2} @ \mathrm{Fe}_{3} \mathrm{O}_{4}\end{array}$ & Sol-gel method & $\begin{array}{c}\text { Paraquat } \\
(10-40 \mathrm{mg} / \mathrm{L})\end{array}$ & $\begin{array}{l}\text { Visible light } \\
\quad(3 \mathrm{~h})\end{array}$ & $\begin{array}{c}98.7 \% \text { removal, } \\
84.7 \% \text { mineralization }\end{array}$ & [118] \\
\hline $\begin{array}{c}\mathrm{B}-\mathrm{TiO}_{2-}^{-} \\
\mathrm{SiO}_{2} / \mathrm{CoFe}_{2} \mathrm{O}_{4}\end{array}$ & $\begin{array}{l}\text { Sol-gel, } \\
\text { hydrothermal } \\
\text { method }\end{array}$ & $\begin{array}{l}\text { Paraquat } \\
(300 \mathrm{mg} / \mathrm{L} \\
\text { COD })\end{array}$ & $\begin{array}{l}\text { Visible light } \\
\qquad(3 \mathrm{~h})\end{array}$ & $\begin{array}{l}\text { 82\% COD removal } \\
\mathrm{k}=0.89 \mathrm{~h}^{-1}\end{array}$ & [119] \\
\hline $\begin{array}{c}\mathrm{TiO}_{2} @ \mathrm{MIL} \\
101(\mathrm{Cr}) @ \mathrm{Fe}_{3} \mathrm{O}_{4}\end{array}$ & Solution synthesis & $\begin{array}{l}\text { Paraquat } \\
(20 \mathrm{mg} / \mathrm{L})\end{array}$ & $\begin{array}{l}\text { UV light } \\
\text { (45 min) }\end{array}$ & $\begin{array}{c}87 \% \text { removal } \\
\mathrm{k}=0.0126 \mathrm{~min}^{-1}\end{array}$ & [120] \\
\hline$\underset{\text { on biochar }}{\mathrm{C}_{3} \mathrm{~N}_{4} / \mathrm{Bi}_{2} \mathrm{O}_{2} \mathrm{CO}_{3} / \mathrm{CoFe}}$ & ${ }_{2}$ bolution synthesis & $\begin{array}{l}\text { Paraquat } \\
(20 \mathrm{mg} / \mathrm{L})\end{array}$ & $\begin{array}{l}\text { Visible light, sunlight, } \\
\text { photo-ozonation, } \\
\text { PMS }\end{array}$ & $\begin{array}{c}99 \% \text { removal in } 1.5 \mathrm{~h} \text { (vis, } \\
0.0596 \mathrm{~min}^{-1} \text { ), } 100 \% \\
\text { mineralization in } 30 \mathrm{~min} \\
\text { (visible-O } 3 \text {-PMS) }\end{array}$ & [121] \\
\hline $\mathrm{CeO}_{2}-\mathrm{Bi}_{2} \mathrm{O}_{3}$ & Co-precipitation & $2,4-\mathrm{D}$ & $\begin{array}{l}\text { Visible light } \\
\quad(13 \mathrm{~h})\end{array}$ & $\begin{array}{l}90 \% \text { removal and COD } \\
\text { decrease }\end{array}$ & [122] \\
\hline$\underset{15}{\mathrm{Fe}_{3} \mathrm{O}_{4} @ \mathrm{WO}_{3} / \mathrm{SBA}-}$ & $\begin{array}{l}\text { Co-precipitation } \\
\text { hydrothermal } \\
\text { method }\end{array}$ & $\begin{array}{c}2,4-\mathrm{D} \\
\left(10^{-6} \mathrm{M}\right)\end{array}$ & $\begin{array}{l}\text { UV light } \\
\quad(4 \mathrm{~h})\end{array}$ & $90.7 \%$ removal & [123] \\
\hline $\mathrm{TiO}_{2}$ nanotubes & Anodization & $\begin{array}{c}2,4-\mathrm{D} \\
(10 \mathrm{mg} / \mathrm{L})\end{array}$ & $\begin{array}{l}\text { Simulated sunlight, } \\
\text { bias } 2.4 \mathrm{~V}(2 \mathrm{~h})\end{array}$ & $\begin{array}{c}97 \% \text { removal } \\
\mathrm{k}=0.0295 \mathrm{~min}^{-1}\end{array}$ & [124] \\
\hline $\mathrm{TiO}_{2}$-acetylacetone & Sol-gel method & $\begin{array}{l}\text { 2,4-D, 4-CPA, } \\
\text { MCPA, MCPB } \\
(\geq 0.2 \mathrm{mM})\end{array}$ & Dark (1 h) & $80-90 \%$ removal & [50] \\
\hline 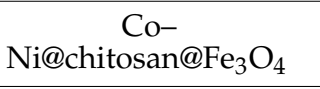 & $\begin{array}{l}\text { Co-precipitation, } \\
\text { reduction }\end{array}$ & $\begin{array}{c}2,4-\mathrm{D} \\
(100 \mathrm{mg} / \mathrm{L})\end{array}$ & $\mathrm{H}_{2} \mathrm{O}_{2} 1-2 \mathrm{~mL}$ & $\begin{array}{c}95.5 \% \text { removal, } \\
\mathrm{k}=0.07517 \mathrm{~min}^{-1}\end{array}$ & [125] \\
\hline polyaniline $/ \mathrm{SnO}_{2}$ & $\begin{array}{l}\text { Polymerization, } \\
\text { precipitation }\end{array}$ & $\begin{array}{c}\text { DDT } \\
(100-500 \mathrm{mg} / \mathrm{L})\end{array}$ & $\begin{array}{l}\text { Microwave irradiation } \\
\text { (12 min) }\end{array}$ & $\begin{array}{l}80 \% \text { removal, } \\
\mathrm{k}=0.20 \mathrm{~min}^{-1}\end{array}$ & [126] \\
\hline $\mathrm{MnO}_{2}$ & Oxidation & $\begin{array}{c}\mathrm{DDT} \\
(0.5 \mathrm{mg} / \mathrm{L})\end{array}$ & PMS (4 h) & $100 \%$ removal & [127] \\
\hline $\mathrm{TiO}_{2}, \mathrm{ZnO}$ & Commercial & $\begin{array}{l}\text { vinclozoline } \\
\text { fenarimol, } \\
\text { malathion, } \\
\text { fenotrothion, } \\
\text { quinalphos, } \\
\text { dimethoate } \\
(0.3 \mathrm{mg} / \mathrm{L})\end{array}$ & $\begin{array}{l}\text { UV light or sunlight, } \\
\text { PS }(250 \mathrm{mg} / \mathrm{L} \\
\left.\mathrm{Na}_{2} \mathrm{~S}_{2} \mathrm{O}_{8}\right) \\
4 \mathrm{~h}\end{array}$ & $\begin{array}{c}70-100 \% \text { removal, except } \\
\text { for fenarimol, } \\
0.0018-0.0292 \mathrm{~min}^{-1} \\
\left(\mathrm{TiO}_{2}\right) ; \\
0.0023-0.0872 \mathrm{~min}^{-1} \\
(\mathrm{ZnO})\end{array}$ & {$[128,129]$} \\
\hline
\end{tabular}

\subsubsection{Glyphosate}

Glyphosate, N-(phosphonomethyl)glycine (PMG), an organophosphate compound, is a highly effective broad-spectrum herbicide, such that glyphosate-based herbicides are the most widely used pesticides worldwide. Several studies have put attention on risks related to the possible carcinogenic, neurotoxic, and endocrine-disrupting effects of glyphosate, 
and to its impact on the aquatic environment [130], giving rise to a strong controversy from the viewpoint of scientific evaluation and legislation. Disagreements in the assessment of the results are mainly related to methodological differences in the evaluation of the available evidence [131]. In the EU, glyphosate approval has been renewed until December 2022; however, the debate remains open.

Crystalline semiconductors with different exposed facets may show substantial variations in adsorption and photocatalytic efficiency. This was demonstrated for anatase $\mathrm{TiO}_{2}$ nanomaterials, exposing a high or low fraction of specific facets. The surface energy of different facets dominated the adsorption of PMG, and the highest Langmuir adsorption capacity $\left(0.88\right.$ molecules $\left./ \mathrm{nm}^{2}\right)$ was observed on $\{201\}-\mathrm{TiO}_{2}$, with the sample also exhibiting the highest photodegradation reaction constant [108]. The better photoactivity was attributed to a more efficient ROS generation, a larger electron transfer and oxygen reduction reaction (ORR) rate. Two-dimensional correlation spectra (2D-COS) and ATR-FTIR analysis proved that each functional group of PMG adsorbed on $\mathrm{TiO}_{2}$ underwent a transformation sequence of a different order.

The size of nanoparticles is another factor that can have a great influence on photocatalytic activity, particularly when approaching extremely small sizes. Investigating cerium dioxide nanoparticles with ultrasmall controllable diameter, synthesized with citric acid as capping agent, Wu et al. observed a significantly size-dependent activity in glyphosate degradation [109]. The finest $\mathrm{CeO}_{2} \mathrm{NPs}(2.1 \mathrm{~nm})$ provided several times higher degradation rates compared to $4.8 \mathrm{~nm}$ NPs, achieving PMG removal in 5 min under UV irradiation and 20 min under visible light, at $\mathrm{pH}$. These hybrid $\mathrm{CeO}_{2}$ nanomaterials exhibited high surface areas, abundant oxygen defects and a good stability of dispersion in water. The excellent photocatalytic efficiency was explained as due not only to the morphology and defectivity, but also on the role of bonded citric acid as electron donor, fostering the regeneration of $\mathrm{Ce}^{3+}$ sites by ligand-to-metal charge transfer. On the other hand, W-doped $\mathrm{ZnO}$ showing large wurtzite crystallites was prepared by a simple precipitation method and tested in PMG photodegradation under simulated solar light [110]. The optimal doping amount was found to be $1.5 \mathrm{~mol} \%$, providing $74 \%$ removal and $30 \%$ mineralization in 180 min with $1.5 \mathrm{~g} / \mathrm{L}$ catalyst dosage.

Among the bismuth-based semiconductors emerging as photocatalysts, bismuth vanadate and tungstate possess a relatively low band gap (about 2.4 and $2.7 \mathrm{eV}$, respectively), resulting in visible light response, and chemical stability against photo-corrosion. Heterojunctions with other semiconductors are frequently examined to enhance their activity. Luo et al. fabricated via a facile two-step hydrothermal method, peanut-like shaped $\mathrm{MoSe}_{2} / \mathrm{BiVO}_{4}$ composites responsive to visible light [112]. The coupling of $\mathrm{MoSe}_{2}$ and $\mathrm{BiVO}_{4}$, forming a heterojunction, enhanced the photocatalytic activity, transfer of photogenerated carriers and the charge separation. The highest photocatalytic performance for the degradation of PMG was observed for $0.15 \mathrm{MoSe}_{2} / \mathrm{BiVO}_{4}$ sample, which also presented high stability and good reusability in the photocatalytic reactions among all the as-prepared composites. $\mathrm{Cu}_{2} \mathrm{~S} / \mathrm{Bi}_{2} \mathrm{WO}_{6}$ composites synthesized by a three-step route, including hydrothermal treatments for the two semiconductors and a subsequent ultrasound-assisted stage for their coupling, displayed a hierarchical flower-like nanostructure, with $\mathrm{Cu}_{2} \mathrm{~S}$ nanoparticles deposited on the surface of $\mathrm{Bi}_{2} \mathrm{WO}_{6}$ nanosheets [113]. These materials proved considerable and stable activity in PMG degradation under visible light, which was explained according to a Z-scheme mechanism that maximizes charge separation, with optimum loading of $\mathrm{Cu}_{2} \mathrm{~S}$ equal to $1 \mathrm{wt} \%$. Cao et al. prepared magnetic $\mathrm{BiOBr} / \mathrm{Fe}_{3} \mathrm{O}_{4}$ nanocomposites photocatalysts via a facile solvothermal process [111]. These catalysts showed excellent photocatalytic activity toward glyphosate degradation in water under visible-light irradiation and magnetic recyclability. The degradation reached $97 \%$, which was higher than that of the pure $\mathrm{BiOBr}$ nanosheets $(85 \%)$ within $60 \mathrm{~min}$. In particular, $\mathrm{BiOBr} / \mathrm{Fe}_{3} \mathrm{O}_{4}$ nanocomposites exhibited high reusability, as after five repeated trials, the percent of degradation of PMG was still more than $90 \%$. The higher photocatalytic activity 
than that of pure $\mathrm{BiOBr}$ was attributed to the efficient separation of photoinduced charge carriers, where $\mathrm{h}^{+}$was shown to be the dominant reactive species in the photodegradation.

Electrochemical oxidation systems were also tested for glyphosate decomposition. A $\mathrm{TiO}_{2}$ photoanode was deposited on boron doped diamond (BDD) by sol-gel coupled with spin coating, using titanium oxysulfate as precursor and obtaining aggregates of anatase nanoparticles [132]. The removal of PMG electrocatalysis in the dark reached $91 \%$ in $5 \mathrm{~h}$, with significant TOC and COD abatement. The photoelectrocatalytic performances under UV irradiation were higher, as expected, and allowed a virtually complete PMG removal in less than $4 \mathrm{~h}$ with lower current density $\left(3 \mathrm{~mA} \mathrm{~cm}^{-2}\right)$. Non-irradiated PMS activation was studied on $\mathrm{Fe}_{3} \mathrm{CeO}_{x}$ prepared by a simple co-precipitation procedure, observing rapid and complete degradation of glyphosate $(100 \mathrm{mg} / \mathrm{L})$ within $15 \mathrm{~min}$, with $85.6 \%$ TOC removal and $80.8 \%$ total nitrogen (TN) removal, using $0.5 \mathrm{mM}$ PMS and $3 \mathrm{~g} / \mathrm{L}$ of catalyst [114]. The outstanding catalytic activity and stability of the material originate from the synergy of iron and cerium, in particular the reductive action of $\mathrm{Fe}^{2+}$ and $\mathrm{Ce}^{3+}$. The $\mathrm{C}-\mathrm{N}$ and $\mathrm{C}-\mathrm{P}$ bonds of glyphosate appeared susceptible to attack by sulfate and hydroxyl radicals, resulting the formation of aminomethylphosphonic acid (AMPA), a typical by-product, and $\mathrm{PO}_{4}{ }^{3-}$ by dephosphorylation, and ultimately driving mineralization.

\subsubsection{Paraquat}

Paraquat (also known as methyl viologen) is a bypiridinium compound, widespread as a fast-acting and non-selective herbicide. It exerts significant toxicity in humans and animals, and recent studies have demonstrated adverse effects on the endocrine system of mammals and on neurogenesis (the generation of new neurons), indicating it as an etiological factor of Parkinson's disease [130].

Supported photocatalysts were prepared depositing $\mathrm{P} 25 \mathrm{TiO}_{2}$ nanopowder on $\mathrm{SiC}$ foam cylinders (16 wt\% loading), by repeated dipping and final annealing [115]. Tests of paraquat $(5-40 \mathrm{mg} / \mathrm{L})$ degradation were conducted in a photocatalytic tubular reactor equipped with a UV-C lightning system $(254 \mathrm{~nm})$, showing improved efficiency of the photocatalytic system compared to photolysis, particularly in the mineralization, which was $90 \%$ after $180 \mathrm{~min}$. Carboxylic acids were identified as the main reaction intermediates. $\mathrm{TiO}_{2}$ was also supported on highly ordered mesoporous silica (SBA-16), preparing nanocomposites with large specific surface area via templated sol-gel route [116]. Batch tests showed that paraquat $(50 \mathrm{mg} / \mathrm{L})$ mixed with a dye was adsorbed and gradually decomposed by SBA-16/ $\mathrm{TiO}_{2}(0.4 \mathrm{~g} / \mathrm{L})$ under UV illumination, reaching $70 \%$ removal after a prolonged reaction time of $24 \mathrm{~h}$. Carbon-modified titania nanomaterial synthesized by hydrolytic sol-gel in the presence of coffee extract was tested in the photodegradation of paraquat (5 to $50 \mathrm{mg} / \mathrm{L}$ ) under UV light, observing a moderate activity with $0.6 \mathrm{~g} / \mathrm{L}$ of $\mathrm{TiO}_{2} / \mathrm{C}$, which was manifold increased with the addition of $10 \mathrm{mM} \mathrm{H}_{2} \mathrm{O}_{2}$ [133]. However, the lack of characterization of the materials prevented the evaluation of the influence of the carbonaceous phase on the functionality. In the extensively studied branch of non-metal doping of $\mathrm{TiO}_{2}$, nitrogen is the reference element, inducing a moderate band gap reduction. $\mathrm{N}$-doped $\mathrm{TiO}_{2}$ samples with nanorice-like morphology, synthesized via hydrothermal method and calcined at different temperatures, were tested in paraquat $(20 \mathrm{mg} / \mathrm{L})$ photodegradation with $1 \mathrm{~g} / \mathrm{L}$ of catalyst [117]. The removal over the uncalcined sample was about $86 \%$ and $62 \%$ after 120 min of UV and visible irradiation, respectively. The decrease of the photoactivity with the treatment temperature was explained as due to the gradual reduction of specific surface area and nitrogen content. These results are comparable to those reported for a $\mathrm{N}$-doped $\mathrm{TiO}_{2}$-based magnetic nanomaterial with a $\mathrm{Fe}_{3} \mathrm{O}_{4}$ core $\left(\mathrm{N}-\mathrm{TiO}_{2} @ \mathrm{SiO}_{2} @ \mathrm{Fe}_{3} \mathrm{O}_{4}\right)$ synthesized by sol-gel and used in paraquat decomposition, showing visible light activity with TOC removal up to $85 \%$ in $180 \mathrm{~min}$ and good reusability [118]. Boron-doped $\mathrm{TiO}_{2}-\mathrm{SiO}_{2}$ prepared by sol-gel was coupled with cobalt ferrite nanoparticles through hydrothermal process [119]. The so-obtained magnetically separable composite, $\mathrm{B}-\mathrm{TiO}_{2}-\mathrm{SiO}_{2} / \mathrm{CoFe}_{2} \mathrm{O}_{4}$, exhibiting low band gap and long charge carrier lifetime, was applied for the decontamination of real and synthetic wastewaters containing recalcitrant compounds, among them the 
pesticides diazinon and paraquat. The latter was completely removed under visible light at the optimized conditions, i.e., COD concentration of $300 \mathrm{mg} / \mathrm{L}$, catalyst loading of $2.5 \mathrm{~g} / \mathrm{L}$ and $\mathrm{pH} 3$, in $3.5 \mathrm{~h}$, with degradation rate constant $0.89 \mathrm{~h}^{-1}$. Another magnetic photocatalyst was prepared coupling $\mathrm{TiO}_{2}$ with $\alpha-\mathrm{Fe}_{2} \mathrm{O}_{3}$ and MIL-101(Cr) metal-organic framework in a three-step solution synthesis procedure [120]. The operating parameters for paraquat photodegradation were optimized, achieving $87 \%$ removal at $20 \mathrm{ppm}$ initial concentration with $0.2 \mathrm{~g} / \mathrm{L}$ of catalyst in $45 \mathrm{~min}$, nonetheless the role of the MOF component was not clearly defined.

Kumar et al. prepared a biochar-supported magnetic ternary heterojunction, g$\mathrm{C}_{3} \mathrm{~N}_{4} / \mathrm{Bi}_{2} \mathrm{O}_{2} \mathrm{CO}_{3} / \mathrm{CoFe}_{2} \mathrm{O}_{4}(\mathrm{BCBF})$, through a multistep precipitation-hydrothermal method [121]. The nano-assembly exhibited high quantum efficiency, charge separation and transport and ROS generation, as revealed by photoluminescence and electrochemical analyses, resulting in excellent visible light activity. The degradation of paraquat was tested in various conditions: visible radiation, natural sunlight, photo-ozonation and presence of peroxymonosulfate. The removal of $20 \mathrm{ppm}$ paraquat with $0.5 \mathrm{~g} / \mathrm{L}$ of BCBF reached 99.3\% under visible radiation in $90 \mathrm{~min}$ and $92.1 \%$ under solar light in $120 \mathrm{~min}$, being manifold faster on the ternary junction than on its single components or binary composites. A combined experiment $\mathrm{BCBF} / \mathrm{PMS} / \mathrm{O}_{3} /$ visible led to complete mineralization in less than $30 \mathrm{~min}$. Moreover, the absence of cyto-toxicity of the nanomaterial was checked by cell viability assay.

\subsubsection{Chlorinated Phenoxyalkanoic Herbicides}

Chlorinated phenoxyalkanoic acids are a family of widespread herbicides considered as priority pollutants. Their most common representative is 2,4-dichlorophenoxyacetic acid (2,4-D), an EDC with toxic and carcinogenic effects, whose partial breakdown can originate other harmful compounds, such as 2,4-dichlorophenol. The photodegradation of 2,4-D was tested under UV irradiation over $\mathrm{Fe}_{3} \mathrm{O}_{4} @ \mathrm{WO}_{3}$ nanomaterials supported on mesoporous silica SBA-15, prepared by the co-precipitation, solvothermal and hydrothermal methods [123]. The magnetic photocatalyst with $5 \% \mathrm{Fe}_{3} \mathrm{O}_{4} @ \mathrm{WO}_{3}$ loading gave $91 \%$ degradation of the herbicide in $4 \mathrm{~h}$. Cerium dioxide and $\mathrm{CeO}_{2}-\mathrm{Bi}_{2} \mathrm{O}_{3}$ mixed oxide synthesized through co-precipitation method were tested in the degradation of 2,4-D under visible light [122]. The mixed catalyst with $30 \mathrm{wt} \% \mathrm{Bi}_{2} \mathrm{O}_{3}$ showed slightly increased photodegradation rate, with a removal of the herbicide of $91 \%$ after $13 \mathrm{~h}$.

The photoelectrochemical oxidation of 2,4-D was investigated on blue $\mathrm{TiO}_{2}$ nanotube (TNT) arrays, fabricated via an electrochemical reduction method with formic acid as the electrolyte [124]. These TNT contained $\mathrm{Ti}^{3+}$ sites responsible for increased conductivity and visible light absorption. Their use as electrodes under simulated solar radiation gave 2,4-D degradation rate constant $\left(0.0295 \mathrm{~min}^{-1}\right)$ more than twice the sum of the rates of electrocatalytic and photocatalytic processes alone.

$\mathrm{TiO}_{2}$-based amorphous hybrid materials synthesized by hydrolytic sol-gel route with the addition of a diketone (acetylacetone) were studied by Pirozzi et al. for the catalytic removal of four related chlorinated aromatic herbicides: 2,4-D, MCPA (4-chloro-2methylphenoxyacetic acid), 4-CPA (4-chlorophenoxyacetic acid), and MCPB (4-(4-chloro2-methylphenoxy) butanoic acid) [50]. The ligand-to-metal interfacial charge transfer complexes (acetylacetonate-Ti) allowed the generation in ambient conditions of extremely stable superoxide radicals. These ROS induced strong oxidative activity in water in the absence of light irradiation or additional oxidants, also by producing $\bullet \mathrm{OH}$ radicals. Removal efficiencies between $80 \%$ and $90 \%$ were observed in 60 min using $0.2 \mathrm{mM}$ initial herbicide concentration and $1 \mathrm{~g} / \mathrm{L}$ of catalyst. At higher concentrations some differences in the process rates were observed; however, the removal of all contaminants tended to be completed in short times, leading to a distribution of oxidation by-products and suggesting a consecutive adsorption-degradation process, supported by the good fitting of the concentration decay curves obtained by double-exponential model. $\bullet \mathrm{O}_{2}{ }^{-}$radicals were 
easily regenerated on the surface of the hybrid catalyst, allowing its efficient reuse. The same catalyst proved effective also in the removal of phenanthrene [50].

The synergy between cobalt and nickel was exploited by Sharma et al., who prepared a bimetallic catalytic system comprising a polymeric chitosan support decorated with redox couple Co-Ni nanoparticles [125]. The magnetically recoverable Co-Ni@CS@ $\mathrm{Fe}_{3} \mathrm{O}_{4}$ nanocomposite was obtained by anchoring $\mathrm{Co}$ and $\mathrm{Ni}$ catalytic centers onto the surface of chitosan. The bimetallic nanocomposite fostered the in situ generation hydroxyl radical species with the addition of $\mathrm{H}_{2} \mathrm{O}_{2}$, catalyzing the oxidative degradation of water contaminants, including 2,4-D. In comparison to its monometallic counterparts, the bimetallic nanocomposite resulted in an enhanced degradation efficiency toward 2,4-D $(95.50 \%)$ and methyl orange dye $(93.14 \%)$ due to a synergistic effect produced by the combination of two metals, and a significant reusability in eight consecutive cycles.

\subsubsection{Other Pesticides}

Dichlorodiphenyltrichloroethane (DDT) was an extremely widespread insecticide that was banned in most countries decades ago, because of its environmental and human toxicity, including endocrine disrupting activity and probable carcinogenity. Nonetheless, its production has decreased but not ceased, as DDT is allowed for disease vectors control (like malaria-transmitting mosquitoes) and is still used locally. Moreover, its chemical stability and lipophilicity make it a persistent organic pollutant with high bioaccumulation tendency, still found in waters and soils. In recent years few works have dealt with the heterogeneous chemical degradation of DDT. Tin dioxide was coupled with a conductive polymer, polyaniline (PANI), to enhance its catalytic activity [126]. PANI/SnO 2 nanohybrids with different compositions were prepared via ultrasound-assisted polymerization of aniline in the presence of $\mathrm{SnO}_{2}$ nanoparticles synthesized by precipitation using Guava extract. Microwave-assisted catalytic degradation of DDT resulted in a fast removal of more than $80 \%$ DDT in very short times (12 min of microwave irradiation), even with pollutant concentrations as high as $500 \mathrm{mg} / \mathrm{L}$ on PANI/ $\mathrm{SnO}_{2}-50 / 50$. A variety of by-products was detected, including relatively low molecular weight ones produced by dechlorination. Three different structures of $\mathrm{MnO}_{2}$ synthesized by an oxidation method in liquid phase were tested in PMS activation for the degradation of DDT [127]. The crystal structure, surface area and $\mathrm{Mn}$ (III) content were individuated as the main properties affecting the catalytic activity. $\alpha-\mathrm{MnO}_{2}$ was the most efficient polymorph, followed by $\gamma-\mathrm{MnO}_{2}$ and $\beta-\mathrm{MnO}_{2}$. Almost complete removal of DDT $(0.5 \mathrm{mg} / \mathrm{L})$ was attained in about $4 \mathrm{~h}$ with $0.5 \mathrm{~g} / \mathrm{L}$ catalyst load, and higher temperature and acidic $\mathrm{pH}$ were observed to increase the efficiency. Sulfate radical was confirmed to be the principal oxidant involved in the process and some breakdown products were identified, resulting from dechlorination and hydroxylation.

Some studies have focused on less widely known agrochemicals with ascertained or likely endocrine disrupting effects. $\mathrm{TiO}_{2}$ and $\mathrm{ZnO}$ are still the most studied photocatalysts and the comparison of their efficiency may give variable results, depending on factors like the considered structure and morphology, besides the chosen target substrate and reaction conditions. Vela et al. studied the combination of persulfate with commercial $\mathrm{TiO}_{2}$ [128] or $\mathrm{ZnO}$ [129] in the degradation of two fungicides (vinclozoline and fenarimol) and four insecticides (malathion, fenotrothion, quinalphos, and dimethoate) with endocrinedisrupting activity. After optimizing the process conditions in a lab photoreactor, they tested it in a pilot-scale plant under natural sunlight, using $200 \mathrm{mg} / \mathrm{L}$ of photocatalyst, $250 \mathrm{mg} / \mathrm{L}$ of $\mathrm{Na}_{2} \mathrm{~S}_{2} \mathrm{O}_{8}$ and $0.3 \mathrm{mg} / \mathrm{L}$ of each pesticide. In $4 \mathrm{~h}$ the target contaminants were in most part removed, except for fenamirol, and a substantial reduction of dissolved organic carbon indicated complete mineralization. The authors reported a higher efficiency of $\mathrm{ZnO}$ compared to $\mathrm{TiO}_{2}$, anyway they did not discuss more in depth the origin of the differences in the behavior of the two materials.

Sharma et al. synthetized porous $\mathrm{WO}_{3} / \mathrm{SiO}_{2}$ monoliths, by vacuum impregnation of sodium tungstate in silica monoliths and calcination [134]. The composite monoliths 
exhibited a connected porous network structure, high surface area and $2.5 \mathrm{eV}$ band gap. Degradation of imidacloprid insecticide (59\%) and methylene blue $(97 \%)$ was recorded under visible-light illumination in $60 \mathrm{~min}$, with good reuse stability.

The problem of the detection of pesticide residuals in liquid matrices was faced by Quan et al., coupling their sensing with the removal [135]. They prepared arrays of 3D tilted $\mathrm{ZnO}$ microrods by chemical bath deposition, following by Ag sputtering, which detected small concentrations of pesticides (the fungicide thiram and some methamidophos compounds) in fruit juices by a surface-enhanced Raman spectroscopy (SERS) method. The same $\mathrm{ZnO} / \mathrm{Ag}$ material revealed promising performance in the degradation of the contaminant under visible irradiation, owing to the Schottky barrier formed by Ag nanoparticles, acting as electron collectors.

\subsection{Photocatalytic and Catalytic Degradation of Pharmaceuticals and Personal Care Products}

The awareness of the pollution caused by pharmaceuticals and personal care products is growing rapidly, as the negative effects of many active ingredients in drugs or components of the most common personal care products are increasingly being recognized. Massive production and ubiquitous use (often individual use), followed by frequent and incorrect disposal, results in the significant presence of these chemicals in wastewater. Among these classes of EDCs, antimycotic triclosan, parabens, and hormones (Figure 11), as well as other pharmaceuticals, such as anti-inflammatory and antibiotic ones, are of great concern.

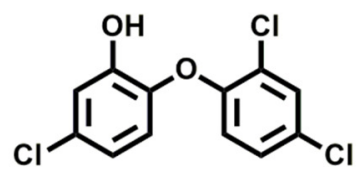

triclosan

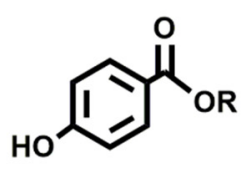

paraben (general structure)

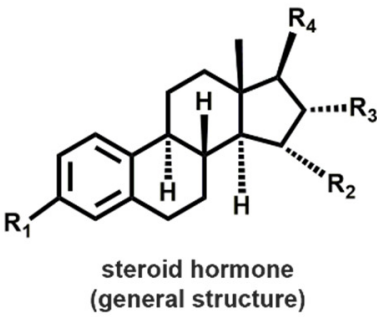

Figure 11. Chemical structures of triclosan, parabens and steroid hormones.

\subsubsection{Triclosan}

Triclosan (5-Chloro-2-(2,4-dichlorophenoxy) phenol, TCS) is an antimicrobial agent contained in some detergents, toothpastes, and other PCPs. Its use has been restricted in several counties because of concerns about bacterial resistance and endocrine disruption activity. The worries about the environmental consequences of the presence of triclosan (TCS) in water are also related to harmful by-products, such as polychlorinated dibenzodioxins [136].

A $\mathrm{TiO}_{2}-\mathrm{rGO}$ composite prepared by hydrothermal method was tested in the photodegradation of triclosan under solar light [137]. At the optimal rGO content of $10 \mathrm{wt} \%$, the catalyst could remove $1 \mathrm{mg} / \mathrm{L}$ of triclosan in $24 \mathrm{~h}$ exposure to sunlight and performed effectively also in secondary-treated effluent matrix, at ambient $\mathrm{pH}$ conditions. Based on scavenging and mineralization experiments the authors proposed a degradation mechanism implying the action of hydroxyl radicals and the removal of chloride. About $85 \%$ of TCS degradation was achieved in the secondary effluent, while $100 \%$ was obtained in pure water after $16 \mathrm{~h}$ of irradiation. A similar nanomaterial produced through a hydrothermal route was proposed by Ojha et al. for triclosan removal [138]. In particular, the authors explored the use of two semiconductor materials $\left(\mathrm{TiO}_{2}\right.$ and cadmium sulfide nanoparticles, CdS), connected through a charge transfer system (graphene) with the aim of enhancing photocatalytic degradation. Triclosan was completely degraded after $6.5 \mathrm{~h}$ of reaction, followed by an overnight irradiation step. The obtained results were attributed to the enhanced charge transfer as well as separation of the photogenerated charge carriers observed in the ternary $\mathrm{CdS} @ \mathrm{TiO}_{2}-\mathrm{rGO}$ nanocomposite.

A Fe $\mathrm{F}_{2} \mathrm{O}_{3}-\mathrm{TiO}_{2} / \mathrm{PVP}$ composite layer was prepared by spray coating a mixture of the commercial oxides and polyvinylpyrrolidone on a glass pipe and tested in triclosan degra- 
dation under solar light in deionized water and simulated greywater effluent [139]. The authors found this immobilization procedure effective, leading to a removal up to $83 \%$, and proposed a decomposition pathway based on the intermediates detected by LC-MS. A similar spray coating technique was used for the deposition of magnetic composites of iron oxide $\left(\alpha-\mathrm{Fe}_{2} \mathrm{O}_{3}\right.$ and $\left.\mathrm{Fe}_{3} \mathrm{O}_{4}\right)$ and carbon nitride $\left(\mathrm{C}_{3} \mathrm{~N}_{4}\right)$ synthesized via a microwave-assisted hydrothermal route [140]. Such catalyst showed interesting results in the degradation of triclosan and ethinylestradiol under visible-light irradiation, particularly a TCS was degraded with up to $46 \%$ of the initial concentration within $8 \mathrm{~h}$, under visible-light irradiation. A $\mathrm{Fe} / \mathrm{Nb}_{2} \mathrm{O}_{5}$ catalyst, prepared by impregnation of iron (1.5 wt $\%$ nominal load) on hydrated niobia and immobilized on calcium alginate spheres, was tested in triclosan degradation in a continuous flow photoreactor, under solar and artificial radiation [136]. The authors showed a promising removal of triclosan and 2,8-dichlorodibenzo-p-dioxin formed as intermediate, with a degradation efficacy up to $80 \%$ being achieved in the best operational conditions; however, they recorded a rapid loss of activity and did not investigate the relationships between properties and functionality.

Highly efficient thin film photocatalysts were investigated by Katal et al. [141]. CuO films were developed through rapid thermal annealing and decorated with Pd nanostructures, which considerably increased optical absorption, improving the photocatalytic performance through the enhancement of surface plasmon resonance, ultimately reaching a value of $99 \%$ in TCS degradation. Thin film photocatalysts were also synthesized by Tiwari et al. [142]. The authors produced nanocomposite mesoporous $\mathrm{Ag}(\mathrm{NPs}) / \mathrm{TiO}_{2}$ thin films through a template assisted synthesis. The oxidative elimination of TCS, under UV-A irradiation, was demonstrated as a function of $\mathrm{pH}$, concentration of triclosan and presence of several co-existing ions. Furthermore, good stability in the multiple use of the obtained nanocomposites was assessed. In addition, the thermal assisted preparation led to a significant enhancement of both charge generation and separation efficiency through improvement of crystallinity and reduction of recombination centers.

Cobalt-doped $\left(\mathrm{Co}-\mathrm{TiO}_{2}\right)$ and cobalt and nitrogen co-doped $\left(\mathrm{Co}-\mathrm{TiO}_{2}-\mathrm{N}\right)$ anatase nanocatalysts were synthesized by an improved hydrothermal method by Ferreira et al. [143]. The $\mathrm{Co}-\mathrm{TiO}_{2}-\mathrm{N}$ catalyst displayed the best photocatalytic activity in the degradation of TCS achieving, under UV (365 nm) and Vis $(450 \mathrm{~nm})$ LED lights irradiation, nearly complete $(>99 \%)$ TCS degradation $(10 \mathrm{mg} / \mathrm{L})$ in $20 \mathrm{~min}$. The reduction of bandgap energies combined with the electron trapping phenomenon, promoted by both $\mathrm{Co}^{3+} / \mathrm{Co}^{2+}$ redox pair and the energy level transitions for the nitrogen-related conduction band, improved catalytic performance. In addition, a mechanism involving mineralization of TCS was reported.

Chen et al. successfully synthesized through solution-based oxidation-precipitation and insertion-crystallization processes spinel-type oxide $\mathrm{Co}_{\mathrm{x}} \mathrm{Mn}_{2-\mathrm{x}} \mathrm{O}_{4}$ to catalyze peroxymonosulfate in the heterogenous degradation of TCS [144], as schematically described in Figure 12. In addition to sulfate radical, the generation of singlet oxygen from lattice oxygen facilitated the metal redox cycle and promoted the heterogeneous PMS activation in TCS oxidation. At initial $\mathrm{pH}$ of 6.8, the authors reported a degradation efficiency up to $96.4 \%$ within $30 \mathrm{~min}$ of reaction. Furthermore, degradation pathways of TCS which involved the breakage of ether bond or cycloaddition reaction were reported.

A green option for TCS removal was proposed by So et al. using recyclable commercial magnetic nanoparticles, which acted as both adsorbent and catalyst component in a Fenton-like process [145]. PMS was used as source of radicals and the effects of $\mathrm{Fe}_{3} \mathrm{O}_{4}$ and PMS dosage, adsorption, $\mathrm{pH}$, and catalyst surface charges were studied. Under the optimum conditions, TCS was completely removed in less than $60 \mathrm{~min}$. The same authors implemented their operational conditions avoiding the use of PMS that showed toxic effect on aquatic animals [146]. Indeed, they demonstrated that PMS can be used to pre-activate catalytic $\mathrm{MnFe}_{2} \mathrm{O}_{4}$ nanoparticles, during this activation step $\mathrm{Mn}^{2+}$ was altered into manganese oxides which oxidize TCS in the succeeding degradation reactions; hence, the direct addition of PMS is no longer required. The results showed that the preactivated catalyst provides satisfactory results with the total removal of TCS in 20 min at neutral $\mathrm{pH}$. 
With a similar purpose, Huang et al. investigated the catalytic performance of $\mathrm{CuO}$ loaded halloysite nanotubes to activate persulfate (PS) to degrade and mineralize TCS [147]. Total removal was achieved in 180 min under optimized conditions. The mechanism study demonstrated that even if radical reactions pathway $\left(\bullet \mathrm{OH}\right.$ and $\left.\bullet \mathrm{O}_{2}{ }^{-}\right)$existed and the non-radical mechanism $\left({ }^{1} \mathrm{O}_{2}\right.$ and surface electron transport) was dominant to the efficient TCS degradation. A detailed investigation on the degradation intermediates indicated that TCS began to break from the aromatic ring containing monochlorine, and the $\mathrm{Cl}$ functional group was gradually substituted. $\mathrm{CO}_{2}$ and $\mathrm{H}_{2} \mathrm{O}$ were generated with breaking of ether bonds. A simultaneous removal of heavy metal, $\mathrm{Cr}(\mathrm{VI})$, and TCS was proposed by Song et al. through an $\mathrm{Fe}_{3} \mathrm{O}_{4}$-activated PS oxidation process [148]. The catalyst was prepared through ultrasonic-assisted reverse coprecipitation, a removal of $87.5 \%$ and $99.5 \%$ was achieved within 120 min for TCS and Cr(VI), respectively. The proposed degradation pathways indicated that sulfate radicals are the primary radical species responsible for TCS degradation, followed by the breakage of ether bond, de-chlorination, and hydroxylation. The study proved that the $\mathrm{Fe}_{3} \mathrm{O}_{4}$-activated PS oxidation process could be used as an effective technique for the simultaneous removal of heavy metal and organic pollutants.

Overall, triclosan contamination has recently been treated by sulfate radical generation, in addition to photocatalysis, often relying on iron compounds, as summarized in Table 4.

Table 4. Summary of representative metal-oxide-based nanomaterials used for the degradation processes of triclosan.

\begin{tabular}{|c|c|c|c|c|c|}
\hline Material & Preparation & Target & Conditions & Results & Ref. \\
\hline $\mathrm{TiO}_{2}-\mathrm{rGO}$ & Hydrothermal route & $\begin{array}{c}\text { TCS } \\
(100 \mathrm{mg} / \mathrm{L})\end{array}$ & Solar light & $\begin{array}{c}85 / 100 \% \text { removal } \\
0.251 \mathrm{~h}^{-1}\end{array}$ & [137] \\
\hline $\begin{array}{l}\mathrm{CdS@TiO}{ }_{2}-\mathrm{rGO} \\
\text { nanocomposite }\end{array}$ & Hydrothermal route & $\begin{array}{c}\text { TCS } \\
(40 \mathrm{ppm})\end{array}$ & visible light & $\begin{array}{c}100 \% \text { removal } \\
2.7 \times 10^{-3} \mathrm{~min}^{-1}\end{array}$ & [138] \\
\hline $\begin{array}{l}\mathrm{Ag}(\mathrm{NPs}) / \mathrm{TiO}_{2} \\
\text { film }\end{array}$ & $\begin{array}{l}\text { Template assisted } \\
\text { synthesis }\end{array}$ & $\begin{array}{c}\text { TCS } \\
(1.0 \mathrm{mg} / \mathrm{L})\end{array}$ & UV-A & $\begin{array}{c}75 \% \text { removal } \\
0.992 \mathrm{mg} / \mathrm{L} / \mathrm{min}\end{array}$ & [142] \\
\hline $\begin{array}{c}\mathrm{Co}, \mathrm{N} \text {-codoped } \mathrm{TiO}_{2} \\
\text { nanoparticles }\end{array}$ & Hydrothermal route & $\begin{array}{c}\text { TCS } \\
(10 \mathrm{mg} / \mathrm{L})\end{array}$ & $\begin{array}{l}\text { UV/Vis LED lights } \\
\text { irradiation }\end{array}$ & $\begin{array}{c}>99 \% \text { removal } \\
0.2340 \pm 0.006 \mathrm{~min}^{-1}\end{array}$ & [143] \\
\hline $\begin{array}{c}\mathrm{Fe}_{2} \mathrm{O}_{3}-\mathrm{TiO}_{2} / \mathrm{PVP} \\
\text { composite }\end{array}$ & Spray coating & $\begin{array}{c}\text { TCS } \\
(1-10 \mathrm{mg} / \mathrm{L})\end{array}$ & Solar light & $\begin{array}{c}83 \% \text { removal } \\
0.3405-0.0687 \mathrm{~min}^{-1}\end{array}$ & [139] \\
\hline $\mathrm{Fe}_{3} \mathrm{O}_{4} / \mathrm{C}_{3} \mathrm{~N}_{4}$ & $\begin{array}{l}\text { Microwave-assisted } \\
\text { hydrothermal route }\end{array}$ & $\begin{array}{c}\text { TCS } \\
\left(4 \times 10^{-5} \mathrm{M}\right)\end{array}$ & Visible-light & $\begin{array}{c}46 \% \text { removal } \\
2.3 \times 10^{-5} \mathrm{~s}^{-1}\end{array}$ & [140] \\
\hline $\mathrm{Fe} / \mathrm{Nb}_{2} \mathrm{O}_{5}$ & Impregnation & TCS & $\begin{array}{l}\text { Solar/artificial } \\
\text { irradiation }\end{array}$ & $80 \%$ removal & [136] \\
\hline $\begin{array}{l}\text { CuO-loaded halloysite } \\
\text { nanotubes }\end{array}$ & Hydrothermal route & $\begin{array}{c}\text { TCS } \\
(2 \mathrm{mg} / \mathrm{L})\end{array}$ & activated PS & $100 \%$ removal & [147] \\
\hline $\mathrm{Co}_{\mathrm{x}} \mathrm{Mn}_{2-\mathrm{x}} \mathrm{O}_{4}$ & $\begin{array}{l}\text { Solution-based oxida- } \\
\text { tion/precipitation } \\
\text { process }\end{array}$ & $\begin{array}{c}\text { TCS } \\
(10 \mathrm{mg} / \mathrm{L})\end{array}$ & activated PMS & $\begin{array}{l}96.4 \% \text { removal } \\
0.106 \mathrm{~min}^{-1}\end{array}$ & [144] \\
\hline $\mathrm{Fe}_{3} \mathrm{O}_{4}$ & commercial & $\begin{array}{c}\text { TCS } \\
(0.03 \mathrm{mM})\end{array}$ & activated PMS & $100 \%$ removal & [145] \\
\hline $\mathrm{MnFe}_{2} \mathrm{O}_{4}$ & commercial & $\begin{array}{c}\text { TCS } \\
(0.03 \mathrm{mM})\end{array}$ & activated PMS & $100 \%$ removal & [146] \\
\hline $\mathrm{Fe}_{3} \mathrm{O}_{4}$ & $\begin{array}{l}\text { Ultrasonic-assisted } \\
\text { reverse coprecipitation }\end{array}$ & $\begin{array}{c}\text { TCS } \\
(5 \mathrm{mg} / \mathrm{L})\end{array}$ & activated PS & $\begin{array}{l}\sim 88 \% \text { removal } \\
0.022 \mathrm{~min}^{-1}\end{array}$ & [148] \\
\hline
\end{tabular}




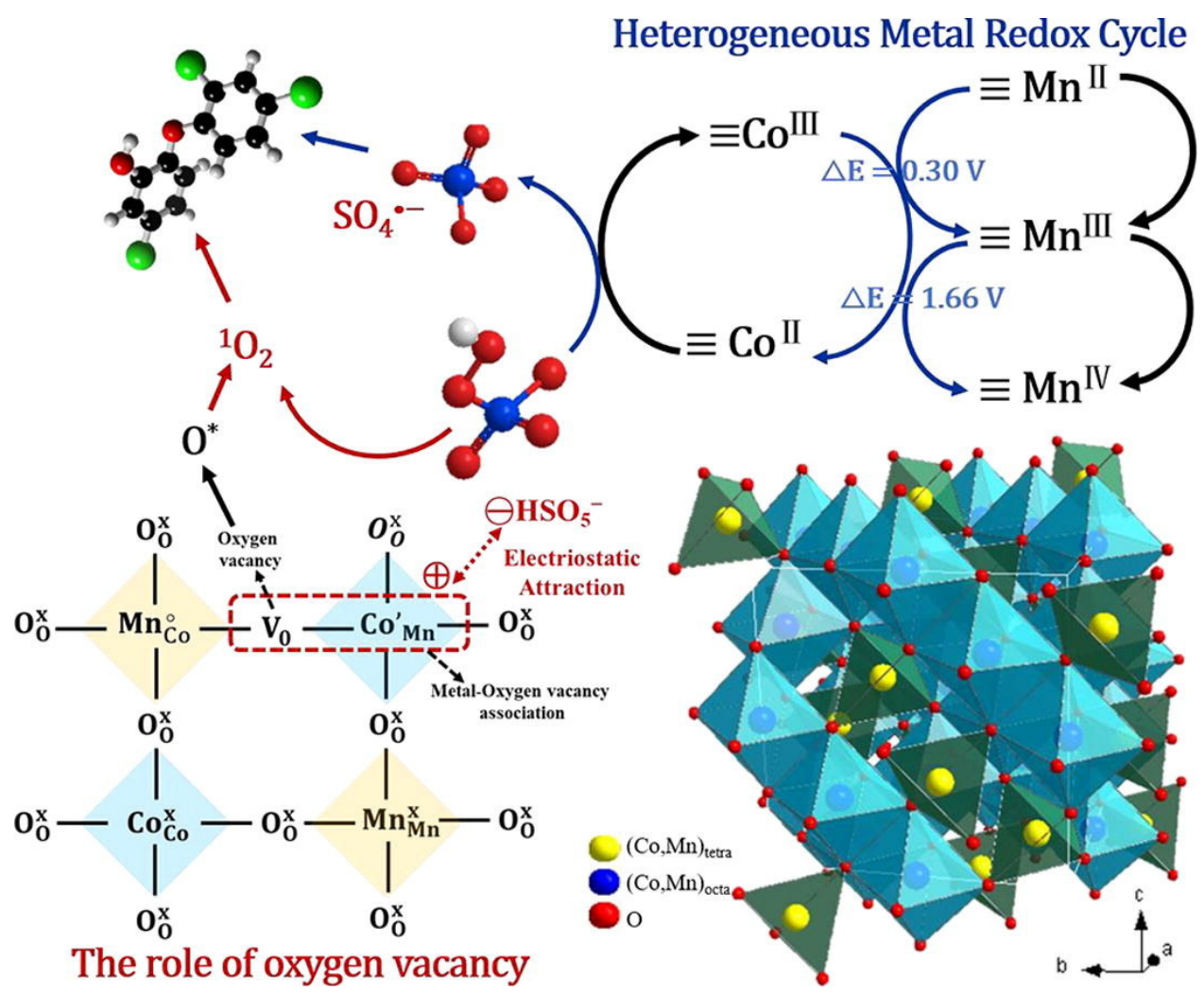

Figure 12. The schematic mechanism of the heterogeneous degradation of triclosan by using spinel-type oxide $\mathrm{Co}_{x} \mathrm{Mn}_{2-x} \mathrm{O}_{4}$, Adapted and reprinted with permission from [144], Copyright (2020) Elsevier.

\subsubsection{Parabens}

Parabens are alkyl esters of 4-hydroxybenzoic acid widely used as preservatives in pharmaceutical and personal care products (PCPs) due to their useful properties, such as good water solubility, chemical stability, low production cost combined with antimicrobial activity. The continuous increase in parabens and their metabolites in water bodies cause adverse health effects including inhibition of thyroid gland, hindrance of reproduction, endocrine disruption. Generally, the most used methods of removing parabens from water and wastewaters just transfer them into another medium, without any degradation. In contrast, photocatalysis represents an alternative technique capable of degrading parabens by using cheaply available solar energy and light-sensitive catalysts [149-151].

Foszpańczyk et al. proved that solar energy, instead of expensive UV light, may be applied either as photocatalytic oxidation or as photosensitized oxidation [152]. The efficiency of noble metal-doped $\mathrm{TiO}_{2}$ nanoparticles in degrading a mixture of parabens (methyl-, ethyl-, propyl, butyl- and benzyl-parabens, MP, EP, PP, BuP and BeP) by simulated and natural sunlight radiation was compared in various water matrixes. They identified the singlet oxygen and hydroxyl radicals as oxidant species for photosensitized and photocatalytic oxidation, respectively. Application of sunlight for both processes led to degradation of parabens which increased with increasing length of the hydrocarbon chain and reached about $90 \%$ of degradation efficacy when tap water was used as matrix.

Self-organized $\mathrm{TiO}_{2}$ supported nanotubes were recently evaluated by Gomes et al. for the photocatalytic degradation of parabens mixtures (MP, EP, PP) [153]. In particular, a one-step anodization method was applied for the $\mathrm{TiO}_{2}$ systems production with the aim to improve the possibility to easily reuse and recover the catalysts. The photocatalytic oxidation was evaluated using two different irradiation sources, UVA, and sunlight. The sunlight radiation, using the most suitable reactor configuration, accounted for $35 \%$ of parabens removal in $60 \mathrm{~min}$. The same authors implemented paraben mixture degradation comparing the ozone-based technologies with photocatalysis [154]. The experiments 
involving UVA with ozone should enhance the parabens' degradation leading to a total removal in about $15 \mathrm{~min}$, while photocatalysis only led to a best result of about $50 \%$ degradation in $120 \mathrm{~min}$. Methyl and ethyl paraben degradation was investigated by Vela et al. [155], with the purpose of assessing the treatment strategy using commercial $\mathrm{TiO}_{2}$ nanopowders (P25, Alfa Aesar and Kronos vlp 7000) in tandem with $\mathrm{Na}_{2} \mathrm{~S}_{2} \mathrm{O}_{8}$ as electron acceptor under natural sunlight. The degradation rate of the studied EDCs was enhanced compared with photolytic tests. In addition, more than $90 \%$ of the $\mathrm{TiO}_{2}$ nanopowders can be easily recovered through ultrafiltration for reuse in further photocatalytic processes.

A series of $\mathrm{CoO}_{x} / \mathrm{BiVO}_{4}$ catalysts with variable cobalt content were synthesized by Petala et al. [156] and tested for the degradation of PP under simulated solar irradiation. Catalysts were synthesized through wet impregnation method and the cobalt addition improved the absorbance in the visible region of $\mathrm{BiVO}_{4}$. Th efficient electron-hole separation, achieved at the p-n junction formed between the p-type $\mathrm{Co}_{3} \mathrm{O}_{4}$ and the n-type $\mathrm{BiVO}_{4}$ semiconductors resulted in an impressive enhancement of the photocatalytic performance. The catalyst loaded with $0.5 \mathrm{wt}$.\% Co allowed to obtain an almost complete degradation of PP (97\%) after 150 min under simulated solar irradiation.

Porous quaternary titanate nanorods, as efficient catalyst for parabens degradation, were successfully synthesized for the first time by Moschogiannaki at al. [157]. A solutionbased method following an ethylene glycol route at room temperature was exploited to produce $\mathrm{Co}_{x} \mathrm{Ni}_{1-x} \mathrm{TiO}_{3}$ nanorods assessed for the photocatalytic degradation of ethyl paraben under both simulated solar and visible-light irradiation. Again, the reduced recombination rates of the photogenerated electrons and holes, given by the synergy between nickel and cobalt cations, resulted in enhanced degradation activity. All nanorods with $\mathrm{Co}_{0.5} \mathrm{Ni}_{0.5} \mathrm{TiO}_{3}$ composition were capable of degrading paraben under simulated solar radiation, with the sample exhibiting the best photocatalytic activity: $92 \%$ paraben degradation occurred after $5 \mathrm{~h}$ of solar irradiation.

To solve the main problem in the photocatalysis processes related to the recombination of the electron-hole pair Sheikhmohammadi et al. investigated the photocatalytic removal of benzylparaben $(\mathrm{BzP})$ using nano- $\mathrm{ZnO}$ catalysts in the presence of hydrogen peroxide [158]. $\mathrm{H}_{2} \mathrm{O}_{2}$ was proposed as exogenous oxidant to generate $\bullet \mathrm{OH}$ extra radicals by reacting with $\mathrm{e}^{-}$. The $\mathrm{BzP}$ removal was conducted under $\mathrm{UV}$ irradiation and the degradation efficiency was evaluated with and without the presence of $\mathrm{H}_{2} \mathrm{O}_{2}$. More than $65 \%$ of $\mathrm{BzP}$ was degraded within 90 min under UV irradiation; under the same operation conditions, the addition of $\mathrm{H}_{2} \mathrm{O}_{2}$ resulted in $100 \%$ degradation efficiency. With the same purpose, Asgari et al. proposed a photocatalytic ozonation treatment of different types of parabens (MP, EP, PP, BuP and BeP) using a combination of $\mathrm{ZnO}$, ozone techniques and UV light source [159]. The results discussed in the study proved that the proposed combined technique, in the best operational condition, enhanced the degradation rate leading to $100 \%$ removal for $\mathrm{MP}, \mathrm{EP}, \mathrm{PP}, \mathrm{BuP}$, and $94 \%$ for $\mathrm{BeP}$ in $20 \mathrm{~min}$.

The main outcomes reported in this section highlight that high percentages of parabens were removed by principally using $\mathrm{TiO}_{2}$ - and $\mathrm{ZnO}$-based nanostructured materials, obtained through different synthetic approaches, and acting under UV and sunlight irradiation. The features and performances of these nanomaterials are summarized in Table 5. 
Table 5. Summary of representative metal-oxide-based nanomaterials used for the degradation of parabens.

\begin{tabular}{|c|c|c|c|c|c|}
\hline Material & Preparation & Target & Conditions & Results & Ref. \\
\hline $\begin{array}{c}\mathrm{Ag} / \mathrm{Pd} / \mathrm{Au} / \mathrm{Pt} \text {-doped } \\
\mathrm{TiO}_{2}\end{array}$ & $\begin{array}{l}\text { photodeposition/sol-gel } \\
\text { method }\end{array}$ & $\begin{array}{c}\text { Paraben mixture } \\
\text { MP, EP, PP, } \\
\text { BuP, BeP } \\
(10 \mathrm{mg} / \mathrm{L})\end{array}$ & Sunlight & $90 \%$ removal & [152] \\
\hline $\begin{array}{l}\mathrm{TiO}_{2} \text { supported } \\
\text { nanotubes }\end{array}$ & $\begin{array}{l}\text { one-step anodic } \\
\text { oxidation method }\end{array}$ & $\begin{array}{c}\text { Paraben mixture } \\
\text { MP, EP, PP } \\
(1 \mathrm{mg} / \mathrm{L})\end{array}$ & UV/Sunlight & $35 \%$ r emoval & [153] \\
\hline $\begin{array}{l}\mathrm{TiO}_{2} \text { supported } \\
\text { nanotubes }\end{array}$ & $\begin{array}{l}\text { one-step anodic } \\
\text { oxidation method }\end{array}$ & $\begin{array}{c}\text { Paraben mixture } \\
\mathrm{MP}, \mathrm{EP}, \mathrm{PP} \\
(1 \mathrm{mg} / \mathrm{L})\end{array}$ & UV/ozone & $100 \%$ removal & [154] \\
\hline $\begin{array}{c}\mathrm{TiO}_{2} \\
\text { nanopowder }\end{array}$ & commercial & $\begin{array}{c}\mathrm{MP}, \mathrm{EP} \\
(300 \mathrm{~g} / \mathrm{L})\end{array}$ & $\begin{array}{c}\text { PS, } \\
\text { natural sunlight }\end{array}$ & $\begin{array}{c}90 \% \text { removal } \\
\left(0.006 \pm 0.005 \mathrm{~min}^{-1}\right)\end{array}$ & [155] \\
\hline $\mathrm{CoO}_{\mathrm{x}} / \mathrm{BiVO}_{4}$ & wet impregnation & $\begin{array}{c}\mathrm{PP} \\
(200-400 \mu \mathrm{g} / \mathrm{L})\end{array}$ & simulated sunlight & $\begin{array}{c}97 \% \text { removal } \\
\left(0.025 \pm 0.001 \mathrm{~min}^{-1}\right)\end{array}$ & [156] \\
\hline $\begin{array}{c}\mathrm{Co}_{x} \mathrm{Ni}_{1-\mathrm{x}} \mathrm{TiO}_{3} \\
\text { nanorods }\end{array}$ & solution-based method & $\begin{array}{c}\mathrm{EP} \\
(250 \mathrm{~g} / \mathrm{L})\end{array}$ & $\begin{array}{l}\text { simulated } \\
\text { solar/visible light }\end{array}$ & $92 \%$ removal & [157] \\
\hline nano-ZnO & commercial & $\begin{array}{c}\mathrm{BzP} \\
(15 \mathrm{mg} / \mathrm{L})\end{array}$ & $\mathrm{UV} / \mathrm{H}_{2} \mathrm{O}_{2}$ & $\begin{array}{l}100 \% \text { removal } \\
\left(0.3305 \mathrm{~min}^{-1}\right)\end{array}$ & [158] \\
\hline nano-ZnO & commercial & $\begin{array}{c}\mathrm{MP}, \mathrm{EP}, \mathrm{PP}, \mathrm{BuP} \\
\text { and BeP } \\
(10 \mathrm{mg} / \mathrm{L})\end{array}$ & UV/ozone & $\begin{array}{c}100 \%, 100 \%, 100 \% \\
100 \% \text { and } 94 \% \text { removal }\end{array}$ & [159] \\
\hline
\end{tabular}

\subsubsection{Steroid Hormones}

Steroid hormones also directly interact with the normal functioning of endocrine systems. At present, waste generated by pharmaceutical industries and human and animal excretions (urine and feces) represent the major source of hormone pollution. The most common natural and synthetic hormones found in the environment include estrone (E1), 17ß-estradiol (E2), estriol (E3), $17 \alpha$-ethinylestradiol (EE2). All these compounds are constituted by a tetracyclic network consisting of a phenolic, two cyclohexane, and one cyclopentane ring [160].

A new class of 'sea-buckthorn-like' composite material, constituted by amorphous $\mathrm{MnO}_{2} \mathrm{NPs}$ decorated titanate nanotubes (TNTs) was developed by Du et al. and used for $17 \beta$-estradiol (E2) degradation [161]. $\mathrm{MnO}_{2}$ was exploited to pre-activate E2 through oneelectron oxidation, while TNTs as the primary photocatalytic center. The synergetic effect of these two processes leads to efficient $\mathrm{E} 2$ removal by $\mathrm{MnO}_{2}$ /TNTs under simulated solar light, with a TOC elimination rate of $82.6 \%$ in $1 \mathrm{~h}$. In addition, a dual-enhanced mechanism was proposed by the authors to interpret the high degradation efficiency: (1) heterojunction structure of $\mathrm{MnO}_{2}$ and TNTs inhibited electron-hole recombination and promoted visiblelight-driven photocatalytic activity, and (2) synergy of pre-oxidation and photocatalysis led to high reactivity on activated E2 radical and $\bullet \mathrm{OH}$ coupling (see Figure 13). $\mathrm{MnO}_{2}$ nanozyme was also selected by Sun et al. for its intrinsic enzyme-like activity to remove $17 \beta$-estradiol [162]. The reported results indicated that the system removed up to $97.3 \%$ of $\mathrm{E} 2$ at $\mathrm{pH}$ 6. In addition, the authors demonstrated that the presence of humic acid, the major component of natural organic matter in aquatic ecosystems, negatively influenced E2 removal. Indeed, humic acid competed with E2 for the catalytic sites of the $\mathrm{MnO}_{2}$ nanozyme surface and thus decreased the affinity between $\mathrm{MnO}_{2}$ and $\mathrm{E} 2$. 


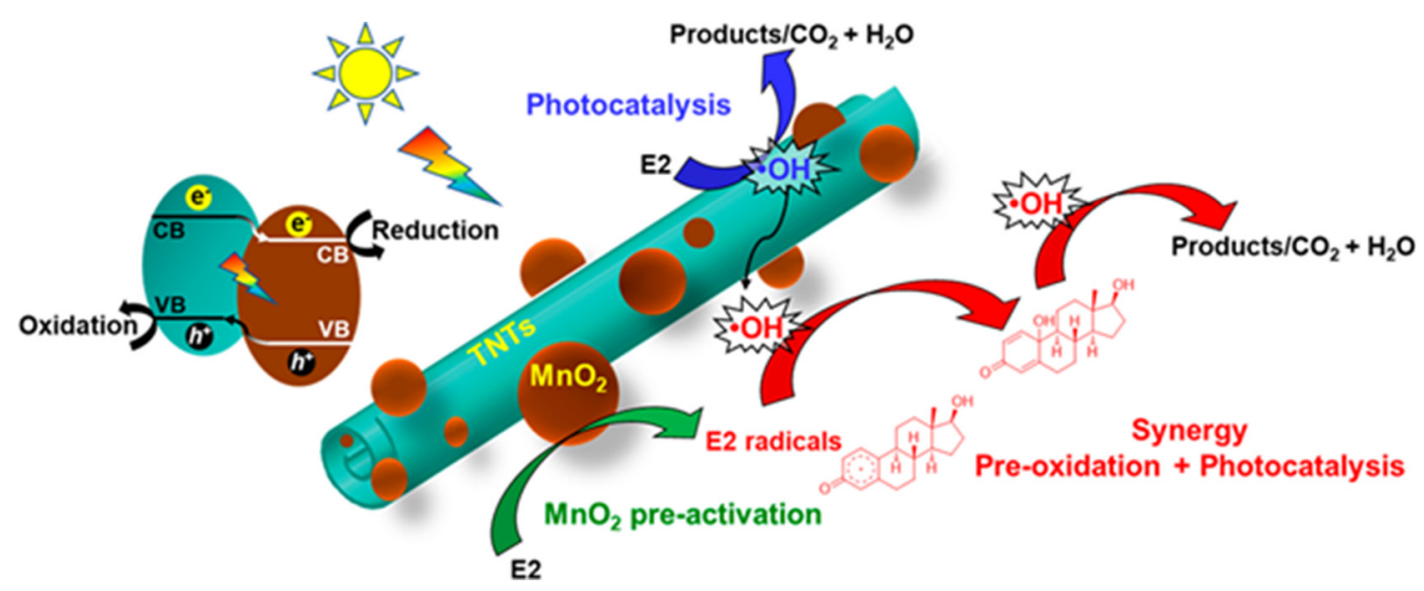

Figure 13. The schematic mechanism of the degradation of $\mathrm{E} 2$ by using $\mathrm{MnO}_{2} \mathrm{NPs}$ decorated titanate nanotubes (TNTs). Reprinted with permission from [161], Copyright (2018) American Chemical Society (ACS).

Immobilized titanium oxide-based composites, made by coupling $\mathrm{TiO}_{2}$ and ironexchanged zeolite (FeZ) and semiconductor $\mathrm{SnS}_{2}$, were applied as solar active photocatalysts for the treatment of $17 \beta$-estradiol (E2) in water and in the presence of $\mathrm{H}_{2} \mathrm{O}_{2}$ [163]. The influence of $\mathrm{pH},\left[\mathrm{H}_{2} \mathrm{O}_{2}\right]$, and composite formulation on the effectiveness of $\mathrm{E} 2$ degradation was deeply investigated. The highest degradation efficacy of $78.1 \%$ was achieved by solar $/ \mathrm{TiO}_{2}-\mathrm{FeZ} / \mathrm{H}_{2} \mathrm{O}_{2}$ process. In addition, the influence of real water matrix constituents such as natural organic matter, nitrates, and carbonates on the effectiveness of E2 degradation was investigated. The authors found that the removal was enhanced in the presence of natural organic matter, while the inhibitory effect was observed in the case of nitrates and carbonates presence. A novel hybrid photocatalyst, made of zinc oxide functionalized with aluminum and polythiophene (Pth), was proposed by Majumder et al. for the photocatalytic degradation of E2 under UVA irradiation [164]. A removal efficiency of about $96 \%$ was achieved in this case. The authors demonstrated that the addition of Pth increased the light-absorbing capacity, while Al doping reduced electron-hole recombination improving the photocatalytic activity. In addition, the choice of the calcination temperature allowed to easily tune crystals size ultimately varying catalyst bandgap.

In the study of Wei et al., a novel synthesis of silver and strontium modified $\mathrm{TiO}_{2}$ nanocomposite, through a sol-gel method, was proposed [165]. Reported results indicated that co-doping remarkably narrowed the band gap of catalyst and inhibited the recombination of electrons and positive holes, enhancing the visible light degradation of the synthetic estrogen $17 \alpha$-ethinylestradiol (EE2). A photocatalytic degradation performance of $94 \%$ was found, and no decrease in the catalyst activity was observed after four cycles, demonstrating high photocatalytic stability coupled with excellent reusability. $\mathrm{TiO}_{2}-\mathrm{ZnO}$ nanocomposites were tested by Menon et al. in the photocatalytic removal of both $17 \beta-$ estradiol and $17 \alpha$-ethinylestradiol under UV and visible irradiation [166]. A detailed study of the decomposition of both estrogenic compounds was conducted over a range of different initial ECs concentrations and 100\% transformation was obtained in the best conditions under visible irradiation. The authors proved that degradation was accompanied by breakdown of the fused ring structure of E2 and EE2, generating smaller molecular weight by-products. Niobium pentoxide was tested in the UV photodegradation of EE2 and three other pharmaceuticals, acetylsalicylic acid, ibuprofen and paracetamol [167]. The effect of calcination temperature of commercial $\mathrm{Nb}_{2} \mathrm{O}_{5}, \mathrm{pH}$ and catalyst dosage were assessed. The higher degradation results were achieved at $\mathrm{pH} 4$, with removal greater than $85 \%$ at the end of $120 \mathrm{~min}$ of photocatalytic reaction.

A novel catalyst based on the combination of $\alpha-\mathrm{FeOOH}$ and $\mathrm{MnO}_{2} @ \mathrm{MnCO}_{3}$ was tested for the first time in the photo-Fenton-like degradation of EE2 [168]. $\alpha$-FeOOH nanoparticles were deposited on the surface of $\mathrm{MnO}_{2} @ \mathrm{MnCO}_{3}$ microspheres. The com- 
bination of these two components results in a great enhancement of the overall catalytic process, indeed almost total degradation of EE2 hormone was achieved after only 2 min of simulated solar irradiation at neutral $\mathrm{pH}$. The high degradation efficacy was attributed to the larger generation of hydroxyl radicals, the primary mediators of the total oxidation for this hormone.

On the other hand, Zhu et al. developed a bismuth-containing photocatalytic biochar $(\mathrm{BiPB})$ using $\mathrm{Bi} / \mathrm{Bi}_{2} \mathrm{O}_{3}$ for the degradation of estrone (E1) [169]. The reaction rate constant inherent to the degradation process was almost tenfold and more than 20 times than that of biochar without bismuth impregnation and pristine $\mathrm{Bi} / \mathrm{Bi}_{2} \mathrm{O}_{3}$, respectively. The chemical investigation revealed that the photocatalytic performance of BiPB composites could be mainly attributed to generation of $\bullet \mathrm{OH}$, which were effectively stabilized in the hierarchical porous structure of biochar. The pre-concentration of estrone on BiPB was catalyzed by the presence of biochar. This latter also improved the separation and transfer efficiency of charge carriers.

High and low UV irradiation conditions were investigated for the degradation of estriol (E3) using iron doped $\mathrm{TiO}_{2}$ nanoparticles [170]. Interestingly, the presence of ferric ion $\left(\mathrm{Fe}^{3+}\right)$, unintentionally added because of the precursors of the synthetic method, played a key role in the photocatalytic generation of hydroxyl radicals $(\bullet \mathrm{OH})$ and estriol (E3) degradation. An efficiency of up to $80 \%$ of E3 degradation was achieved in both irradiation regimes [166]. To obtain a fast and efficient degradation of estrone (E1) and $17 \alpha$-ethinylestradiol (EE2), de Oliveira et al. proposed the use of nanotubular oxide arrays grown on Ti-0.5wt $\% \mathrm{~W}$ under irradiation with ultraviolet (UV) and visible light [171]. The presence of $\mathrm{WO}_{\mathrm{x}}$ species and amorphous $\mathrm{WO}_{3}$ in the oxide layer resulting from the doping of $\mathrm{TiO}_{2}$ with tungsten allowed to obtain a reduction in charge separation and an extended wavelength range for photoexcitation, ultimately leading to percentage removals of EE2 and E1 were $66 \%$ and 53.4\%, respectively, after only 2 min of treatment and under UV irradiation.

The application of magnetite nanoparticles coated with polyacrylic acid and immobilized on mesoporous silica matrix support was investigated as alternative catalysts to conventional Fenton processes for the removal of estrogens (E1, E2, EE2) by GonzálezRodríguez et al. [172]. After the optimization of the operational variables, high removal percentages (above 90\%) were obtained. Furthermore, the ease of catalyst recovery, due to their superparamagnetic properties, represented a significant advantage for their separation and reuse in different successive sequential cycles. Bayode et al. proved the efficiency of a new sustainable visible-light active $p$ - $n$ heterojunction composite with carbon interlayer from $\mathrm{ZnO}, \mathrm{GO}$ and Carica papaya seeds as carbon source prepared via microwave assisted technique [173]. The degradation of four steroid estrogens, E1, E2, E3 and EE2, was investigated. A degradation efficacy $>89 \%$, as high as $98 \%$, was obtained in single solute systems, while in real wastewater samples, efficiency of $63-78 \%$ estrogen removal was achieved. Moreover, the addition of $1 \% \mathrm{H}_{2} \mathrm{O}_{2}$ further raised photodegradation of estrogens to $100 \%$ in $10 \mathrm{~min}$.

Finally, $\mathrm{WO}_{3}$ films, functionalized with silver and platinum metal nanoparticles, were successfully synthesized by a simple drop-casting method by Costa et al. [174]. The photoinduced activity of the obtained systems was investigated for progesterone hormone degradation in aqueous solution under polychromatic irradiation, exploring also electrochemical assisted configuration. Photoelectrochemical characterization showed that the functionalization with metallic NPs accelerates electron transport and increases the separation of the photogenerated electrons and holes. The highest photocatalytic activity, about $27 \%$ of degradation efficacy, was obtained for the $\mathrm{Pt} / \mathrm{WO}_{3}$ system in the irradiated electrochemical configuration.

The main outcomes reported in this section highlight that high removal percentages of steroid hormones were obtained under different conditions, in terms of chemical nature and preparation method of $\mathrm{Me}_{\mathrm{x}} \mathrm{O}_{\mathrm{y}}$ photocatalysts as well as type of irradiation, as schematically reported in Table 6. 
Table 6. Summary of representative metal-oxide-based nanomaterials used for the degradation of steroid hormones.

\begin{tabular}{|c|c|c|c|c|c|}
\hline Material & Preparation & Target & Conditions & Results & Ref. \\
\hline $\begin{array}{c}\mathrm{MnO}_{2} \mathrm{NPs} \\
\text { decorated titanate } \\
\text { nanotubes }\end{array}$ & hydrothermal method & $\begin{array}{c}\mathrm{E} 2 \\
(4 \mu \mathrm{M})\end{array}$ & $\begin{array}{c}\text { simulated solar } \\
\text { light }\end{array}$ & $\begin{array}{l}82.6 \% \text { removal } \\
\left(0.198 \mathrm{~min}^{-1}\right)\end{array}$ & [161] \\
\hline $\mathrm{MnO}_{2}$ nanozyme & commercial & $\begin{array}{c}\mathrm{E} 2 \\
(1 \mathrm{mg} / \mathrm{L})\end{array}$ & $\begin{array}{l}\text { Enzyme-like } \\
\text { activity }\end{array}$ & $\begin{array}{l}97.3 \% \text { removal } \\
\left(0.0131 \mathrm{~min}^{-1}\right)\end{array}$ & [162] \\
\hline $\begin{array}{c}\mathrm{TiO}_{2}-\mathrm{Fe} \\
\text { zeolite/SnS }\end{array}$ & Low $\mathrm{T} /$ solution method & $\begin{array}{c}\mathrm{E} 2 \\
(5 \mu \mathrm{M})\end{array}$ & Solar light $/ \mathrm{H}_{2} \mathrm{O}_{2}$ & $\begin{array}{c}78.1 \% \text { removal } \\
\left(0.01539 \mathrm{~min}^{-1}\right)\end{array}$ & [163] \\
\hline $\begin{array}{l}\text { Al-polythiophene } \\
\text { doped } \mathrm{ZnO}\end{array}$ & Co-precipitation & $\begin{array}{c}\mathrm{E} 2 \\
(1 \mathrm{mg} / \mathrm{L})\end{array}$ & UV-A irradiation & $\begin{array}{l}96 \% \text { removal } \\
\left(0.4451 \mathrm{~h}^{-1}\right)\end{array}$ & [164] \\
\hline $\begin{array}{c}\text { Ag, Sr-modified } \\
\mathrm{TiO}_{2}\end{array}$ & Sol-gel & $\begin{array}{c}\mathrm{EE} 2 \\
(10 \mathrm{mg} / \mathrm{L})\end{array}$ & Visible light & $\begin{array}{l}94 \% \text { removal } \\
\left(0.1699 \mathrm{~min}^{-1}\right)\end{array}$ & [165] \\
\hline $\mathrm{Nb}_{2} \mathrm{O}_{5}$ & commercial & $\begin{array}{c}\text { EE2 } \\
(10 \mathrm{mg} / \mathrm{L})\end{array}$ & UV irradiation & $85 \%$ removal & [167] \\
\hline $\begin{array}{l}\text { a-FeOOH doped } \\
\mathrm{MnO}_{2} @ \mathrm{MnCO}_{3} \\
\text { microsphere }\end{array}$ & $\begin{array}{l}\text { surface oxida- } \\
\text { tion/hydrothermal } \\
\text { reaction }\end{array}$ & $\begin{array}{c}\mathrm{E} 3 \\
(0.5 \mathrm{mg} / \mathrm{L})\end{array}$ & $\begin{array}{l}\text { simulated solar } \\
\text { irradiation }\end{array}$ & $90 \%$ removal & [168] \\
\hline Fe-doped $\mathrm{TiO}_{2}$ & Hydrothermal/sol-gel & $\begin{array}{c}\text { E3 } \\
(10 \mu \mathrm{M})\end{array}$ & $\begin{array}{l}\text { High/low UV } \\
\text { irradiation }\end{array}$ & $\begin{array}{c}80 \% \text { removal } \\
\left(0.009-0.003 \mathrm{~min}^{-1} /\right. \\
\left.0.005-0.016 \mathrm{~min}^{-1}\right)\end{array}$ & [170] \\
\hline $\mathrm{Bi} / \mathrm{Bi}_{2} \mathrm{O}_{3}$ & Impregnation method & $\begin{array}{c}\text { E1 } \\
(10.4 \mu \mathrm{mol} / \mathrm{L})\end{array}$ & $\begin{array}{l}\text { UV-vis light } \\
\text { irradiation }\end{array}$ & $\begin{array}{l}\sim 95 \% \text { removal } \\
\left(0.045 \mathrm{~min}^{-1}\right)\end{array}$ & [169] \\
\hline $\begin{array}{c}\mathrm{TiO}_{2}-\mathrm{ZnO} \\
\text { nanocomposite }\end{array}$ & $\begin{array}{l}\text { non-aqueous sol-gel } \\
\text { process }\end{array}$ & $\begin{array}{c}\text { E2, EE2 } \\
(0.05-10 \mathrm{mg} / \mathrm{L})\end{array}$ & $\begin{array}{l}\text { UV and visible } \\
\text { irradiation }\end{array}$ & $\begin{array}{l}\sim 100 \% \text { removal } \\
\left(\text { E2: } 0.022 \mathrm{~min}^{-1},\right. \\
\left.\text { EE2: } 0.013 \mathrm{~min}^{-1}\right)\end{array}$ & [166] \\
\hline $\begin{array}{c}\text { W-doped } \\
\text { nanotubular } \mathrm{TiO}_{2}\end{array}$ & $\begin{array}{l}\text { Electrochemical } \\
\text { synthesis }\end{array}$ & $\begin{array}{c}\text { E1, EE2 } \\
(10 \mathrm{mg} / \mathrm{L})\end{array}$ & $\begin{array}{c}\text { UV and visible } \\
\text { light }\end{array}$ & $\begin{array}{c}53.4 \%, 66 \% \text { removal } \\
\left(\text { EE2: } 0.001215 \mathrm{~min}^{-1}\right)\end{array}$ & [171] \\
\hline $\mathrm{Fe}_{3} \mathrm{O}_{4} @ \mathrm{SBA} 15$ & $\begin{array}{l}\text { water-in-oil } \\
\text { microemulsion/sol-gel } \\
\text { techniques }\end{array}$ & $\begin{array}{c}\text { E1, E2, EE2 } \\
(100-500 \mu \mathrm{g} / \mathrm{L})\end{array}$ & Fenton-like & $\begin{array}{l}\text { } \sim 90 \% \text { removal } \\
\left(\mathrm{E} 1: 0.160-2.708 \mathrm{~h}^{-1}\right. \\
\text { E2: } 0.228-2.713 \mathrm{~h}^{-1} \\
\left.\text { EE2: } 0.214-3.211 \mathrm{~h}^{-1}\right)\end{array}$ & [172] \\
\hline $\begin{array}{c}\text { (GO)-Carbon- } \mathrm{ZnO} \\
\text { nanostructures }\end{array}$ & $\begin{array}{l}\text { microwave assisted } \\
\text { technique }\end{array}$ & $\begin{array}{l}\text { E1, E2, E3, EE2 } \\
(5 \mathrm{mg} / \mathrm{L})\end{array}$ & visible light & $\begin{array}{l}\text { 89-98\% removal } \\
\text { (E1: } 0.01019 \mathrm{~min}^{-1} \\
\text { E2: } 0.01236 \mathrm{~min}^{-1} \\
\text { E3: } 0.01286 \mathrm{~min}^{-1} \\
\left.\text { EE2: } 0.01567 \mathrm{~min}^{-1}\right)\end{array}$ & [173] \\
\hline $\begin{array}{c}\mathrm{Ag} / \mathrm{Pt} \\
\text { functionalized } \\
\mathrm{WO}_{3} \text { films }\end{array}$ & Drop casting & $\begin{array}{c}\text { Progesterone } \\
(0.35 \mathrm{mg} / \mathrm{L})\end{array}$ & $\begin{array}{l}\text { polychromatic } \\
\text { irradiation, } \\
\text { bias }+0.7 \mathrm{~V} \text { vs. } \\
\mathrm{Ag} / \mathrm{AgCl}\end{array}$ & $\begin{array}{c}\sim 27 \% \text { removal } \\
\left(\mathrm{Ag} / \mathrm{WO}_{3}: 0.001061 \mathrm{~min}^{-1}\right. \\
\left.\mathrm{Pt} / \mathrm{WO}_{3}: 0.001086 \mathrm{~min}^{-1}\right)\end{array}$ & [174] \\
\hline
\end{tabular}

\subsubsection{Other Pharmaceuticals}

Pharmaceutical compounds, such as antibiotics, as well as antiviral, anti-inflammatory, analgesic, and hormone drugs, are mostly found in water ecosystems because of their difficult removal through traditional techniques. These classes of drugs are designed to have biological effects, so they the undesired exposure can have serious implications for human health and fauna, including interference with the endocrine system. Another risk related to antibiotics is the development of antibiotic resistance by bacteria and other microorganisms. Sources of environmental contamination by pharmaceuticals include municipal wastewater, improper disposal of drugs, human excretion, livestock farming, hospitals effluents, and pharmaceutical industry [37]. Therefore, these chemicals are widely 
studied in terms of toxicological risks, as well as degradation strategies. In recent years, a large number of research works and reviews have been dedicated to the removal of these contaminants from water and wastewater by means of processes based on metal oxide nanomaterials $[37,175,176]$. Here, an overview is presented with some examples related to drugs of significant concern.

$\mathrm{TiO}_{2}$-based nanostructured materials and membranes have mostly been applied in photocatalytic systems for the removal of antibiotics, such as amoxicillin [177], erythromycin [178], and tetracycline [179]. However, the degradation of tetracycline has been explored using a variety of other metal oxide nanomaterials, often in photo-responsive heterojunctions, such as those based on $\mathrm{ZnO}[180,181]$, tungsten oxides [182,183], or bismuthmolybdenum mixed oxide [184]. Other antibiotics raising interest as water contaminants are levofloxacin [185], nitrofurantoin [186], metronidazole [187], and sulfamethoxazole [188]. Metal oxide nanomaterials have been also used in the catalytic and photocatalytic degradation of several anti-inflammatory and analgesic compounds, such as acetaminophen (well-known as paracetamol) through catalysts based on $\mathrm{TiO}_{2}$ [189], $\mathrm{WO}_{3}$ [190], $\mathrm{ZnO}$ [191], $\mathrm{CuO} \mathrm{Fe}_{\mathrm{x}} \mathrm{O}_{\mathrm{y}}$ or $\mathrm{Co}_{3} \mathrm{O}_{4}$ [141,192]. Similarly, $\mathrm{TiO}_{2}$ and $\mathrm{ZnO}$-based photocatalysts were employed for the degradation of anti-inflammatory compounds diclofenac [193,194] and ibuprofen [195]. In most of these cases, the photocatalytic performances of the oxides were enhanced by doping or coupling with other semiconductors.

\subsection{Degradation of Other EDCs}

Important groups of EDCs not belonging to the previously presented classes include polyhalogenated biphenyls and diethyl ethers, polyaromatic hydrocarbons and substituted phenols (Figure 14). Polychlorinated biphenyls (PCBs) are a group of environmentally persistent halogenated organic compounds that had been massively produced in past decades for use as insulators, coolants, and lubricants in transformers, capacitors, and other electrical equipment, owing to their chemical stability, low inflammability, and good miscibility. The hazards for human health and the environment related to PCBs and to some carcinogenic derivatives (such as polychlorinated dibenzo-p-dioxins and dibenzofurans) imposed the discontinuance of their production and the disposal within 2028. However, large amounts of PCBs are still used or stored, thus causing severe pollution upon losses, also because of their long half-lives [196,197]. The hydrophobic structure of biphenyls and polyaromatic hydrocarbons hinders their interaction with substantially hydrophilic metal oxide nanomaterials. In fact, in a heterogeneous degradation process, although the ROS generated on the catalyst's surface can diffuse in solution to short distances, allowing oxidation reactions also in homogeneous phase, the adsorption of the target molecule on the surface is generally a fundamental step. The modification of the surface properties to improve its affinity toward the target contaminant is often a fruitful strategy to enhance the process rate and selectivity. To this aim, the use of cyclodextrins has been proposed, since these cyclic oligosaccharides possess a rather lipophilic inner cavity, a hydrophilic outer surface and a truncated-cone shape that enable them to form inclusion complexes with hydrophobic organic pollutants through host-guest interactions. Khammar et al. grafted carboxymethyl- $\beta$-cyclodextrin on hydrothermal $\mathrm{Fe}_{3} \mathrm{O}_{4} @ \mathrm{TiO}_{2}$ nanoparticles and evaluated the photocatalytic performance of this hybrid nanomaterial in the removal of PCBs from transformer oil with UV light [196]. Cyclodextrin functionalization promoted the adsorption and successive degradation of PCBs with a yield up to $83 \%$ in 16 min, with oil:ethanol ratio of 1:5, and the photocatalyst maintained a sufficient stability in five reuses after a simple regeneration by washing in water. The UV-photoinduced degradation process of planar and non-planar PCBs was studied over $\mathrm{TiO}_{2}$ and $\mathrm{CdS} / \mathrm{TiO}_{2}$ nanomaterials obtained by $\mathrm{Ti}(\mathrm{IV})$ butoxide hydrolysis on CdS quantum dots. Interestingly, some of the PCBs were removed faster by the heterostructure, while others by bare $\mathrm{TiO}_{2}$, which was explained by the differences in the interactions between the respective radical intermediates and the surface of the photocatalysts [197]. 


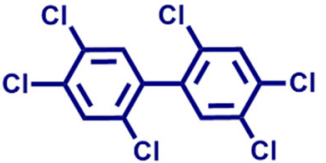

polychlorinated biphenyl (PCB)

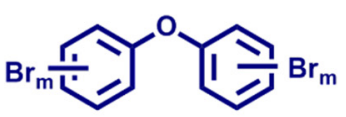

polybrominated diphenyl ether (PBDE)

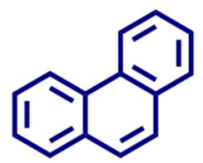

phenanthrene

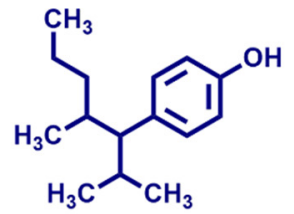

4-nonylphenol

Figure 14. Chemical structures of typical polychlorinated biphenyl, polybrominated diphenyl ether, polycyclic aromatic hydrocarbon (phenanthrene) and alkylphenol.

Plasma treatment was also applied for the removal of polychlorobiphenyls, using an electrode composed of sponge modified by multi-walled carbon nanotubes, on which $\mathrm{CuO} @ \mathrm{Cu}$ and Ag nanowires were attached [198]. The efficiency of the dielectric barrier discharge was improved by the synergistic effects of all components, leading to promising and stable removal efficiency of phenol and 2,4,5-trichlorobiphenyl. The degradation of the latter contaminant reached $65 \%$ in $60 \mathrm{~min}$ of reaction at an input voltage of $30 \mathrm{~V}$.

It was suggested that in order to push the degradation of recalcitrant pollutants such as halogenated aromatics toward mineralization, oxidative processes should be coupled with reductive ones. A novel method of Advanced Oxidation/Reduction Processes was therefore proposed, relying on the simultaneous generation of both oxidative and reductive agents. For PCBs degradation, sulfite was added together with $\mathrm{TiO}_{2}$ under UV irradiation to form $\mathrm{SO}_{3} \bullet-$ reductive radicals. The degradation performances of PCBs $(12 \mathrm{mg} / \mathrm{L})$ were improved up to $98.5 \%$ degradation in $60 \mathrm{~min}$ at $\mathrm{pH} 7$ and at the optimal sulfite $/ \mathrm{TiO}_{2}$ ratio of 1:1 [199].

Polybrominated diphenyl ethers (PBDEs) are a series of aromatic compounds commonly added as flame retardants in the production of electronic equipment, building materials and textiles. The widespread use of PBDEs makes them ubiquitous in the environment. They are classified as persistent organic pollutants and pose health risks related to their bioaccumulation and ability to cause thyroid dysfunctions and developmental neurotoxicity like PCBs. In the challenging decomposition of PBDEs the need for reductive mechanisms seems to acquire great importance, for debromination. A photocatalytic consecutive reduction-oxidation one-pot method was applied by Lei et al. to remove $2,2^{\prime}, 4,4^{\prime}$-tetrabromodiphenyl ether (BDE47) in the presence of a $\mathrm{rGO} / \mathrm{TiO}_{2}$ composite in anoxic conditions (Ar purging) [200]. The reduction became faster in acetonitrile-water solution; however, the key for successful debromination was the addition of a small amount of methanol to the water solution. This system yielded the complete debromination and mineralization of BDE47 within $14 \mathrm{~h}$. Methanol inhibited the recombination of $\mathrm{e}^{-} / \mathrm{h}^{+}$ pairs, accelerating the formation of hydroxyl radicals by $\mathrm{h}^{+}$consumption, thus promoting the direct reduction of BDE47 by photogenerated electrons. The same authors reported complete debromination of BDE47 also without light irradiation, by $\mathrm{Cu} / \mathrm{TiO}_{2}$ in the presence of hydrazine and by $1 \% \mathrm{Pd} / \mathrm{TiO}_{2}$ in isopropanol containing $\mathrm{NaOH}$ at $40^{\circ} \mathrm{C}$. Metallic $\mathrm{Pd}$ activated a catalytic transfer hydrogenation mechanism. Two Br-free products were obtained, diphenyl ether and dibenzofuran, attributed to the hydrogenation and coupling reactions, respectively [201]. A composite photocatalyst with Z-scheme charge transfer was developed through a three-step approach: $\mathrm{Cu}_{2} \mathrm{O}$ films prepared by electrochemical deposition were coated with $\mathrm{rGO}$ and $\mathrm{TiO}_{2}$ (P25) [202]. BDE47 reductive removal tested under simulated solar irradiation showed that $1 \%$ rGO gave the best enhancement of charge transfer in combination with $70 \% \mathrm{TiO}_{2}$. However, the removal reached only $56 \%$ in $3 \mathrm{~h}$, confirming the recalcitrance of PBDEs to degradation.

Polycyclic aromatic hydrocarbons (PAHs) are a large group or molecules generally originated from combustion processes and widely distributed in the environment because of atmospheric transport, wet and dry deposition, and exchange processes between environmental matrices. Other sources of contamination include oil spills and water production. Acute or chronic exposure to PAHs causes risks to humans, animals, and plants, including 
inflammatory response, carcinogenity, endocrine and reproductive disorders [203]. The high stability of PAHs makes them recalcitrant to biological degradation and also hampers their chemical degradation. In recent years, an increasing number of works have dealt with photocatalytic removal of PAHs from water or soil samples, using mainly modified $\mathrm{TiO}_{2}$ or $\mathrm{ZnO}$ [204]. ZnO-based nanocomposites were prepared by one-pot co-precipitation with small fractions of $\mathrm{MnO}$ (a p-type semiconductor), obtaining p-n junctions, as demonstrated by a thorough electrochemical characterization, which evidenced changes in the flat band potential of $\mathrm{ZnO}$ and an increase in the transient time constant related to the electron transport [205]. Photodegradation tests of anthracene in alkaline ethanol-water solution under UV irradiation showed a fast removal with the optimal MnO content $(2.25 \mathrm{wt} \%)$, although anthraquinone was identified as the main product, indicating only partial degradation. The adsorption of PAHs can be greatly promoted by the presence of graphene or similar structures, owing to $\pi-\pi$ interactions. For instance, $\mathrm{ZnO} / \mathrm{Ag} / \mathrm{GO}$ nanocomposite obtained by precipitation of $\mathrm{Ag}$ and $\mathrm{ZnO}$ in a graphene oxide suspension adsorbed naphthalene with a remarkable adsorption capacity, estimated as $500 \mathrm{mg} \mathrm{g}^{-1}$. In a successive stage under visible-light irradiation, adsorbed naphthalene was photodegraded, resulting in a high removal of the pollutant $(50 \mathrm{mg} / \mathrm{L})$ with a relatively low dosage of nanomaterial $(0.25 \mathrm{~g} / \mathrm{L})$ [206].

Metal hexacyanoferrates (HCF), with general formula $\mathrm{M}_{k}\left[\mathrm{Fe}(\mathrm{CN})_{6}\right] \cdot x \mathrm{H}_{2} \mathrm{O}$, have been proposed as photocatalytic compounds, coupled with oxide semiconductors. For example, Rachna et al. prepared nanocomposites of encapsulated $\mathrm{TiO}_{2}, \mathrm{ZnO}$ or $\mathrm{Fe}_{2} \mathrm{O}_{3}$ nanoparticles with ZnHFC nanocubes, adopting simple precipitation procedures assisted by plant extracts $[207,208]$. These materials were found effective in the degradation and mineralization of 3-, 4- and 5-cyclic aromatic hydrocarbons, such as chrysene, benzanthracene and benzopyrene, under sunlight exposure for $24 \mathrm{~h}$. The enhanced photocatalytic activity was attributed to the reduced band gap, increased surface area and enhanced charge separation in the formed heterostructures. Interestingly, a significant activity was also detected in the dark, which was not further examined by the authors. A catalytic system composed of $\mathrm{Fe}_{3} \mathrm{O}_{4}$ particles incorporated into wood biomass and added persulfate was tested for the remediation of real sediments contaminated with 16 different PAHs [209]. The oxidation efficiency was related to the number of rings in their structure, and the faster removal of high-ring PAHs (with four to six rings) was attributed to their stronger affinity for biochar.

The intimate coupling of photocatalysis and biodegradation approach was also applied for the decontamination of water from PAHs. The investigation of $\mathrm{Cu} / \mathrm{N}$-codoped $\mathrm{TiO}_{2}$ nanoparticles prepared by a sol-gel method and coated on PTFE carriers along with a suitable bacterial consortium [210] showed a slight contribution of biodegradation in the conversion and mineralization of pyrene under UV and visible irradiation and revealed alterations the composition and structure of the bacterial community during the process, especially with UV light. Composites of manganese oxide nanosheets with cubic silver orthophosphate $\left(\mathrm{Mn}_{3} \mathrm{O}_{4} / \mathrm{MnO}_{2}-\mathrm{Ag}_{3} \mathrm{PO}_{4}\right)$, prepared by precipitation, exhibited high photocatalytic activity in the degradation of phenanthrene under visible-light irradiation [211]. The efficiency was improved applying ICPB systems fabricated by coating polyurethane porous carriers with the photocatalyst and then forming biofilms from an activated sludge (Figure 15).

Alkylphenols, especially 4-nonylphenol (4-NP), are strong endocrine disruptors with estrogen-like action. They are often found in water as breakdown product of alkylphenol ethoxylates, nonionic surfactants with wide domestic, industrial, and agricultural use [212]. In the case of nonylphenol removal, a viable approach to improve the affinity of the catalyst surface toward the target is the functionalization with non-polar groups, as demonstrated by Tang et al., who obtained hydrophobic titanium oxide nanotubes by reaction with perfluorooctyl triethoxysilane [213]. The introduction of exposed perfluorooctyl groups induced an increase of the water contact angle on the surface from $21.1^{\circ}$ to $128.4^{\circ}$. The adsorption rate of the hydrophobic 4-NP on the modified $\mathrm{TiO}_{2}$ nanotubes was 4 times higher than on bare ones, which resulted in a moderate increase of photodegradation 
efficiency of about $15 \%$. The degradation performances were also tested in the presence of other hydrophilic pollutants, namely atrazine, paraquat and potassium butylxanthate, to compare the results and check the interference effects, confirming the efficiency of the modified photocatalyst. The molecular imprinting approach was adopted in the design of a tin (IV) oxide electrode exposing high-energy facets for 4-NP electrocatalytic oxidation [214]. 4-NP molecules were immobilized on carboxylated $\mathrm{SiO}_{2}$ and then immersed in a $\mathrm{SnO}_{2}$ sol derived from $\mathrm{SnCl}_{4}$. After hydrothermal process etching of $\mathrm{SiO}_{2}$ and calcination at $400{ }^{\circ} \mathrm{C}$, the obtained $\mathrm{SnO}_{2}$ nanoparticles were coated on FTO. Such electrode effectively removed 4-NP from industrial wastewater at applied potential of $1.8 \mathrm{~V}$, suppressing human estrogenic activity and enhancing the biodegradability of the treated water. Nonylphenol, being more persistent, lipophilic, and toxic than the parent chemicals, is often found in rivers and lakes and is an indicator of contamination of sediments [215]. The treatment of real river sediments containing 4-NP was studied using $\mathrm{Fe}_{3} \mathrm{O}_{4}$ particles deposited by co-precipitation on a bio-derived support, bamboo biochar, and sodium persulfate. The catalytic performance of the system was highly dependent on $\mathrm{pH}$ and catalyst dosage: $85 \%$ degradation of 4-NP was achieved at $\mathrm{pH} 3$ using a load of $3.33 \mathrm{~g} / \mathrm{L}, 2.3 \times 10^{-5} \mathrm{M}$ PS and equimolar initial concentration $\left(2.3 \times 10^{-5} \mathrm{M}\right)$ of the contaminant. An analogous system $\left(\mathrm{Fe}_{3} \mathrm{O}_{4}\right.$ particles supported on wood biomass used with PS) was tested in similar conditions for the removal of 16 PAHs from real sediments [209].
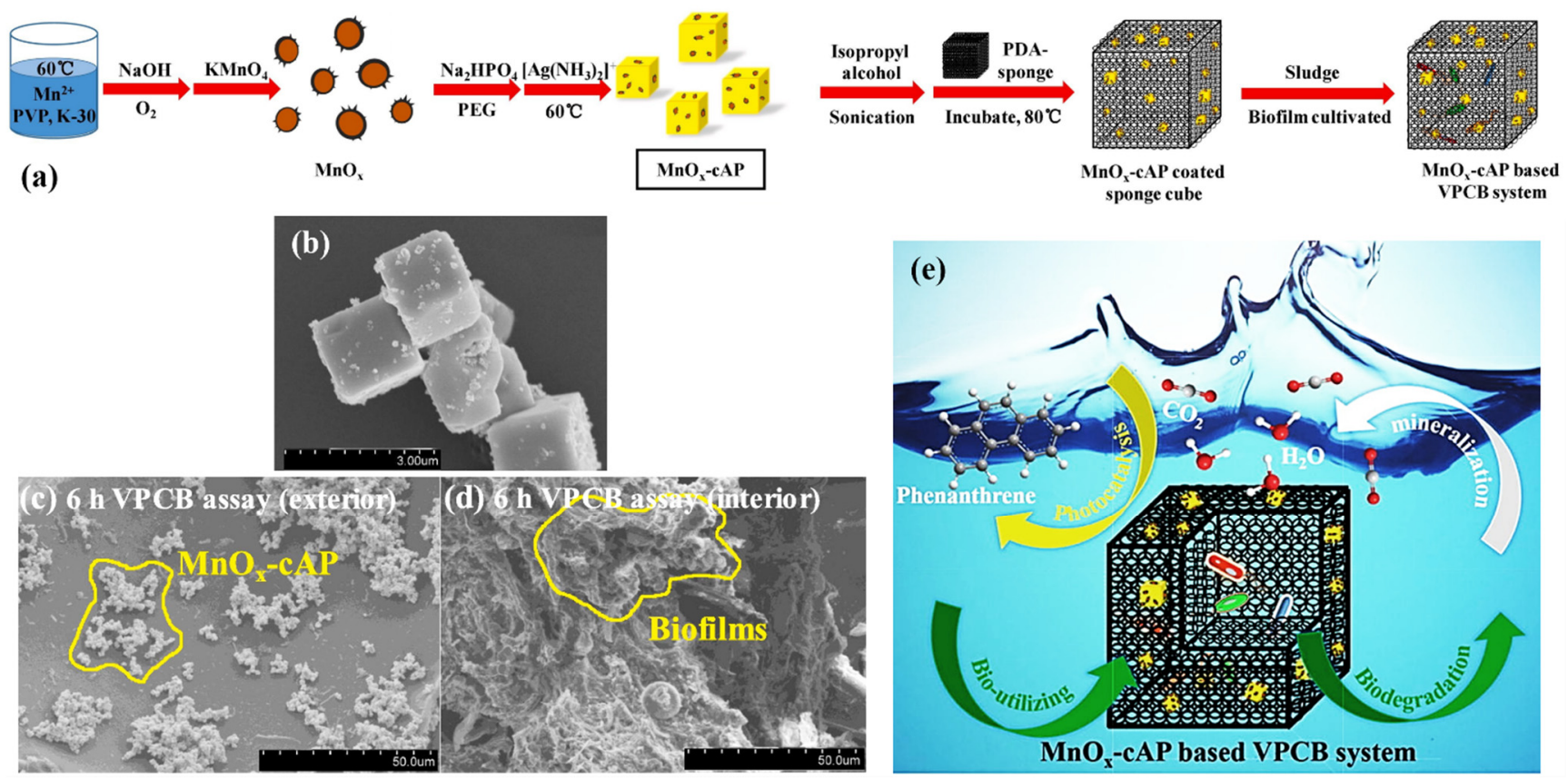

Figure 15. Sketch of the preparation of $\mathrm{MnO}_{\mathrm{x}}$ on $\mathrm{Ag}_{3} \mathrm{PO}_{4}$ cubes $\left(\mathrm{MnO}_{\mathrm{x}}-\mathrm{cAP}\right)$, followed by coating on polyurethane sponge (a); SEM micrograph of the $\mathrm{MnO}_{\mathrm{x}}-\mathrm{cAP}$ isolated (b) and coated (c), along with the biofilm (d); scheme of the coupled visible light photocatalysis and biodegradation (VPCB) process (e). Adapted with permission from [211], Copyright (2019), Elsevier.

An interdisciplinary study [216] focused on the effects of typical nanomaterials employed in water treatment, i.e., $\mathrm{Fe}_{2} \mathrm{O}_{3}$ and $\mathrm{Fe}_{3} \mathrm{O}_{4}$ nanoparticles and multi-wall carbon nanotubes, on the degradation of 4-NP at the water-sediment interface and on the functions of the natural bacterial communities in sediments. It demonstrated that iron oxides promoted the direct 4-NP degradation, moreover their incorporation by bacteria enhanced the biodegradation processes by bacterial enzymes. Therefore, the presence of biocompatible inorganic nanomaterials can reveal a synergistic effect in the decontamination, promoting the microbial activity. This kind of study evidences the limited knowledge currently available on the fate of nanomaterials accidentally released in water and on their interactions with 
the biosphere, suggesting a direction for future research integrating chemistry, material science, and environmental science.

\section{Conclusions and Perspectives}

Endocrine Disrupting Compounds (EDCs) comprise a lot of chemicals such as sexsteroid hormone mimics, pesticides, fertilizers, medicinal drugs, plasticizers, derived from the waste of industries, agriculture, pharmaceutics, and sewage treatment plants. The rising concerns of worldwide use of EDCs and their dangerous effects on human health are continuously attracting increasing attention due to their gradual accumulation and persistence in the environment. Therefore, the issues originating from the contamination of water resources (freshwater, seawater, wastewater and drinking water) are stimulating several research groups to define and develop strategies for an effective removal of EDCs from water. The main ones include physical, chemical, or biological processes. Among them, chemical degradation, which is based on oxidative mechanisms, is aimed at transforming the organic pollutants in less hazardous products and ideally arises in its complete mineralization to $\mathrm{H}_{2} \mathrm{O}, \mathrm{CO}_{2}$ and other inorganic molecules. In this context, photocatalysis has emerged as a fascinating process for the removal of EDCs from wastewater. However, other heterogeneous catalytic processes were also defined for their degradation, such as those founded on Fenton reaction, generation of sulfate radicals, electrochemical and piezocatalytic processes. Further techniques to enhance the production of ROS include low temperature plasma, ozonation and the use of radical precursors.

In all cases, a key role is played by the designed materials employed as catalysts. Research on the design and use of new and effective nanostructured materials aimed at EDCs decontamination has prospered because of the growing awareness of this problem. From the outline offered in this review on metal oxide-based nanomaterials reported in recent years, it emerges that beside the well-studied $\mathrm{TiO}_{2}, \mathrm{ZnO}$, suitably modified by doping or coupling with other semiconductors, relatively innovative materials such as $\mathrm{WO}_{3}, \mathrm{Cu}_{\mathrm{x}} \mathrm{O}, \mathrm{MnO}_{\mathrm{x}}$, and bismuth oxides are gaining attention, especially as photocatalysts, and frequently mixed as heterojunctions, allowing for a wider visible light absorption and more effective charge separation. On the other hand, iron oxides and other redoxactive semiconductors show remarkable results in non-irradiated AOPs, e.g., Fenton-like mechanism and the activation of persulfate or peroxymonosulfate, that make it possible to overcome the restrictions related to photoreactors. The synthesis procedure and conditions have a crucial role in determining the structure and functional properties of complex nanomaterials. Wet chemical methods, in particular, hydrothermal and sol-gel, offer great flexibility and as a result are the most widely applied.

Although many advances have been made by virtue of the design and use of these new nanostructured materials based on hybrid, composite or co-doped metal oxides, some questions remain open yet. Therefore, the enhancement of nanomaterial stability and the feasibility of (photo)catalysts separation and reuse are both challenging tasks to improve their use and potential commercialization for this aim. Indeed, large investments are necessary to produce these semiconductor metal oxide-based nanomaterials for their application in large-scale processes of water treatment. Consequently, important goals should be to define useful and sustainable strategies to prepare low-cost nanomaterials through simple steps, following the principles of green chemistry, as well as to recuperate and regenerate the (photo)catalysts for subsequent reuses. Indeed, the dispersed form of the nanostructures in water is highly appreciable for degradation, then the immediate separation of used nanomaterials by centrifugation or filtration after EDCs degradation is recommended to avoid long-term contact with decontaminated water. Anyway, such separation steps can be expensive or difficult to operate on a large scale; therefore, the fabrication of catalysts supported on suitable scaffolds or coated on reactive surfaces and membranes, assuring an optimal dispersion of the active phase may result advantageous, even though it may decrease the catalytic efficiency. 
Moreover, a growing number of works deal with the mechanism, pathway, and byproducts of the contaminant degradation process. These key aspects should always be considered to understand the relationships between the properties and activity and to evaluate the environmental impact of the treatment, aiming to maximize the mineralization of the pollutants, avoiding the risk of secondary contamination by harmful or unknown products. Such a holistic approach may assist the development of materials optimized either for specific target contaminants or for the removal of wide range of undesired species. It is envisioned that in the future, more research will be devoted to the combination of different AOPs, boosting the overall efficiency and facilitating the integration of these steps in water treatment plants or water remediation systems. Such combined systems should be designed so to enhance the synergism between their components. The achievement of these goals should not be separated from the optimized design of the (photo)reactors, which is decisive for efficient catalytic and photocatalytic degradation processes, preferably exploiting as well as possible the energy of natural sunlight. For these reasons, future works should be more focused on a complete assessment of the water treatment issue and on the prospective technological implementation, and the collaborative efforts between chemists, environmental scientists, material scientists and chemical engineers could pave and manage the way in this direction.

Author Contributions: Conceptualization, C.I. and G.V.; writing-original draft preparation, C.I., A.B., B.S. and G.V.; writing-review and editing, C.I. and G.V.; supervision, G.V.; project administration, G.V. All authors have read and agreed to the published version of the manuscript.

Funding: This research received no external funding.

Conflicts of Interest: The authors declare no conflict of interest.

\section{References}

1. Vieira, W.T.; De Farias, M.B.; Spaolonzi, M.P.; Da Silva, M.G.C.; Vieira, M.G.A. Latest Advanced Oxidative Processes Applied for the Removal of Endocrine Disruptors from Aqueous Media-A Critical Report. J. Environ. Chem. Eng. 2021, 9, 105748. [CrossRef]

2. Vieira, W.T.; De Farias, M.B.; Spaolonzi, M.P.; Da Silva, M.G.C.; Vieira, M.G.A. Endocrine-Disrupting Compounds: Occurrence, Detection Methods, Effects and Promising Treatment Pathways-A Critical Review. J. Environ. Chem. Eng. 2021, 9, 104558. [CrossRef]

3. Pironti, C.; Ricciardi, M.; Proto, A.; Bianco, P.M.; Montano, L.; Motta, O. Endocrine-Disrupting Compounds: An Overview on Their Occurrence in the Aquatic Environment and Human Exposure. Water 2021, 13, 1347. [CrossRef]

4. Kabir, E.R.; Rahman, M.S.; Rahman, I. A Review on Endocrine Disruptors and Their Possible Impacts on Human Health. Environ. Toxicol. Pharmacol. 2015, 40, 241-258. [CrossRef] [PubMed]

5. Schjenken, J.E.; Green, E.S.; Overduin, T.S.; Mah, C.Y.; Russell, D.L.; Robertson, S.A. Endocrine Disruptor Compounds-A Cause of Impaired Immune Tolerance Driving Inflammatory Disorders of Pregnancy? Front. Endocrinol. 2021, 12, 4. [CrossRef] [PubMed]

6. Gao, X.; Kang, S.; Xiong, R.; Chen, M. Environment-Friendly Removal Methods for Endocrine Disrupting Chemicals. Sustainability 2020, 12, 7615. [CrossRef]

7. Medhi, R.; Marquez, M.D.; Lee, T.R. Visible-Light-Active Doped Metal Oxide Nanoparticles: Review of Their Synthesis, Properties, and Applications. ACS Appl. Nano Mater. 2020, 3, 6156-6185. [CrossRef]

8. Yoon, Y.; Truong, P.L.; Lee, D.; Ko, S.H. Metal-Oxide Nanomaterials Synthesis and Applications in Flexible and Wearable Sensors. ACS Nanosci. Au 2021. [CrossRef]

9. Singh, K.R.; Nayak, V.; Singh, J.; Singh, A.K.; Singh, R.P. Potentialities of Bioinspired Metal and Metal Oxide Nanoparticles in Biomedical Sciences. RSC Adv. 2021, 11, 24722-24746. [CrossRef]

10. Costantini, A.; Venezia, V.; Pota, G.; Bifulco, A.; Califano, V.; Sannino, F. Adsorption of Cellulase on Wrinkled Silica Nanoparticles with Enhanced Inter-Wrinkle Distance. Nanomaterials 2020, 10, 1799. [CrossRef]

11. Selvaraj, M.; Hai, A.; Banat, F.; Haija, M.A. Application and Prospects of Carbon Nanostructured Materials in Water Treatment: A Review. J. Water Process Eng. 2020, 33, 100996. [CrossRef]

12. Ojha, A.; Tiwary, D.; Oraon, R.; Singh, P. Degradations of Endocrine-Disrupting Chemicals and Pharmaceutical Compounds in Wastewater with Carbon-Based Nanomaterials: A Critical Review. Environ. Sci. Pollut. Res. 2021, 28, 30573-30594. [CrossRef] [PubMed]

13. Lu, F.; Astruc, D. Nanocatalysts and Other Nanomaterials for Water Remediation from Organic Pollutants. Coord. Chem. Rev. 2020, 408, 213180. [CrossRef] 
14. Bilal, M.; Rasheed, T.; Mehmood, S.; Tang, H.; Ferreira, L.F.R.; Bharagava, R.N.; Iqbal, H.M.N. Mitigation of EnvironmentallyRelated Hazardous Pollutants from Water Matrices Using Nanostructured Materials-A Review. Chemosphere 2020, 253, 126770. [CrossRef] [PubMed]

15. González-González, R.B.; Parra-Arroyo, L.; Parra-Saldívar, R.; Ramirez-Mendoza, R.A.; Iqbal, H.M.N. Nanomaterial-Based Catalysts for the Degradation of Endocrine-Disrupting Chemicals-A Way Forward to Environmental Remediation. Mater. Lett. 2022, 308, 131217. [CrossRef]

16. Colborn, T.; vom Saal, F.S.; Soto, A.M. Developmental Effects of Endocrine-Disrupting Chemicals in Wildlife and Humans. Environ. Health Perspect. 1993, 101, 378-384. [CrossRef]

17. Dirac, P.; Kapitza, P.; Zichichi, A. Statement from the Work Session on Environmental Endocrine-Disrupting Chemical: Neural, Endocrine and Behavioral Effects. Toxicol. Ind. Health 1998, 14, 1-8.

18. Short, P. Statement from the Work Session on Health Effects of Contemporary-Use Pesticides: The Wildlife/Human Connection. Toxicol. Ind. Health 1999, 15, 1-5. [CrossRef]

19. Colborn, T.; Clement, C. Chemically-Induced Alterations in Sexual and Functional Development; Princeton Scientific Pub. Co.: Princeton, NJ, USA, 1992.

20. Thomas Zoeller, R.; Brown, T.R.; Doan, L.L.; Gore, A.C.; Skakkebaek, N.E.; Soto, A.M.; Woodruff, T.J.; Vom Saal, F.S. EndocrineDisrupting Chemicals and Public Health Protection: A Statement of Principles from the Endocrine Society. Endocrinology 2012, 153, 4097-4110. [CrossRef]

21. Register-Notices. Available online: https://Www.Epa.Gov/Endocrine-Disruption/Endocrine-Disruptor-Screening-ProgramEdsp-1998-Federal (accessed on 28 December 2021).

22. Chemicals Strategy for Sustainability towards a Toxic-Free Environment; European Commision: Brussels, Belgium, 2020.

23. La Merrill, M.A.; Vandenberg, L.N.; Smith, M.T.; Goodson, W.; Browne, P.; Patisaul, H.B.; Guyton, K.Z.; Kortenkamp, A.; Cogliano, V.J.; Woodruff, T.J.; et al. Consensus on the Key Characteristics of Endocrine-Disrupting Chemicals as a Basis for Hazard Identification. Nat. Rev. Endocrinol. 2020, 16, 45-57. [CrossRef]

24. Liu, Z.H.; Kanjo, Y.; Mizutani, S. A Review of Phytoestrogens: Their Occurrence and Fate in the Environment. Water Res. 2010, 44, 567-577. [CrossRef] [PubMed]

25. Combarnous, Y. Endocrine Disruptor Compounds (EDCs) and Agriculture: The Case of Pesticides. C. R. Biol. 2017, 340, 406-409. [CrossRef] [PubMed]

26. González-Davis, O.; Chauhan, K.; Zapian-Merino, S.J.; Vazquez-Duhalt, R. Bi-Enzymatic Virus-like Bionanoreactors for the Transformation of Endocrine Disruptor Compounds. Int. J. Biol. Macromol. 2020, 146, 415-421. [CrossRef] [PubMed]

27. Dichiarante, V.; Cavallo, G.; Metrangolo, P. Endocrine-Disrupting Pollutants Properties Affecting Their Bioactivity, Remediation, and Detection. Curr. Opin. Green Sustain. Chem. 2021, 30, 100485. [CrossRef]

28. Barra, R.O.; Chiang, G.; Saavedra, M.F.; Orrego, R.; Servos, M.R.; Hewitt, L.M.; McMaster, M.E.; Bahamonde, P.; Tucca, F.; Munkittrick, K.R. Endocrine Disruptor Impacts on Fish from Chile: The Influence of Wastewaters. Front. Endocrinol. 2021, 12, 208. [CrossRef]

29. Al Sharabati, M.; Abokwiek, R.; Al-Othman, A.; Tawalbeh, M.; Karaman, C.; Orooji, Y.; Karimi, F. Biodegradable Polymers and Their Nano-Composites for the Removal of Endocrine-Disrupting Chemicals (EDCs) from Wastewater: A Review. Environ. Res. 2021, 202, 111694. [CrossRef]

30. Wang, J.; Wang, S. Reactive Species in Advanced Oxidation Processes: Formation, Identification and Reaction Mechanism. Chem. Eng. J. 2020, 401, 126158. [CrossRef]

31. Serpone, N.; Artemev, Y.M.; Ryabchuk, V.K.; Emeline, A.V.; Horikoshi, S. Light-Driven Advanced Oxidation Processes in the Disposal of Emerging Pharmaceutical Contaminants in Aqueous Media: A Brief Review. Curr. Opin. Green Sustain. Chem. 2017, 6, 18-33. [CrossRef]

32. Rizzo, L.; Malato, S.; Antakyali, D.; Beretsou, V.G.; Đolić, M.B.; Gernjak, W.; Heath, E.; Ivancev-Tumbas, I.; Karaolia, P.; Lado Ribeiro, A.R.; et al. Consolidated vs New Advanced Treatment Methods for the Removal of Contaminants of Emerging Concern from Urban Wastewater. Sci. Total Environ. 2019, 655, 986-1008. [CrossRef]

33. Canle, M.; Fernández Pérez, M.I.; Santaballa, J.A. Photocatalyzed Degradation/Abatement of Endocrine Disruptors. Curr. Opin. Green Sustain. Chem. 2017, 6, 101-138. [CrossRef]

34. Ushavipinachandran, V.; Rajendran, S.; Badagoppam Haroon, K.H.; Ashokan, I.; Mondal, A.; Bhunia, S.K. Detoxification of Endocrine Disruptors in Water Using Visible-Light-Active Nanostructures: A Review. ACS Appl. Nano Mater. 2020, 3, 11659-11687. [CrossRef]

35. Wang, R.; Ma, X.; Liu, T.; Li, Y.; Song, L.; Tjong, S.C.; Cao, L.; Wang, W.; Yu, Q.; Wang, Z. Degradation Aspects of Endocrine Disrupting Chemicals: A Review on Photocatalytic Processes and Photocatalysts. Appl. Catal. A Gen. 2020, 597, 117547. [CrossRef]

36. Kumar, A.; Sharma, V.; Kumar, A.; Krishnan, V. Nanomaterials for Photocatalytic Decomposition of Endocrine Disruptors in Water. In Nanostructured Materials for Environmental Applications; Springer International Publishing: Berlin/Heidelberg, Germany, 2021; pp. 299-320.

37. Velempini, T.; Prabakaran, E.; Pillay, K. Recent Developments in the Use of Metal Oxides for Photocatalytic Degradation of Pharmaceutical Pollutants in Water-A Review. Mater. Today Chem. 2021, 19, 100380. [CrossRef]

38. Luciani, G.; Imparato, C.; Vitiello, G. Photosensitive Hybrid Nanostructured Materials: The Big Challenges for Sunlight Capture. Catalysts 2020, 10, 103. [CrossRef] 


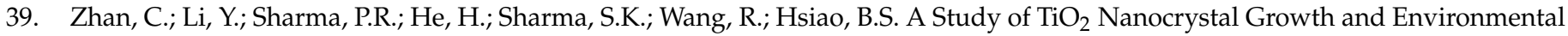
Remediation Capability of $\mathrm{TiO}_{2} / \mathrm{CNC}$ Nanocomposites. RSC Adv. 2019, 9, 40565-40576. [CrossRef] [PubMed]

40. Sharma, P.R.; Sharma, S.K.; Antoine, R.; Hsiao, B.S. Efficient Removal of Arsenic Using Zinc Oxide Nanocrystal-Decorated Regenerated Microfibrillated Cellulose Scaffolds. ACS Sustain. Chem. Eng. 2019, 7, 6140-6151. [CrossRef]

41. Zhang, C.; Li, Y.; Shen, H.; Shuai, D. Simultaneous Coupling of Photocatalytic and Biological Processes: A Promising Synergistic Alternative for Enhancing Decontamination of Recalcitrant Compounds in Water. Chem. Eng. J. 2021, 403, 126365. [CrossRef]

42. Yu, M.; Wang, J.; Tang, L.; Feng, C.; Liu, H.; Zhang, H.; Peng, B.; Chen, Z.; Xie, Q. Intimate Coupling of Photocatalysis and Biodegradation for Wastewater Treatment: Mechanisms, Recent Advances and Environmental Applications. Water Res. 2020, 175, 115673. [CrossRef]

43. Scaria, J.; Gopinath, A.; Nidheesh, P.V. A Versatile Strategy to Eliminate Emerging Contaminants from the Aqueous Environment: Heterogeneous Fenton Process. J. Clean. Prod. 2021, 278, 124014. [CrossRef]

44. Kumar, A.; Rana, A.; Sharma, G.; Naushad, M.; Dhiman, P.; Kumari, A.; Stadler, F.J. Recent Advances in Nano-Fenton Catalytic Degradation of Emerging Pharmaceutical Contaminants. J. Mol. Liq. 2019, 290, 111177. [CrossRef]

45. Xiao, S.; Cheng, M.; Zhong, H.; Liu, Z.; Liu, Y.; Yang, X.; Liang, Q. Iron-Mediated Activation of Persulfate and Peroxymonosulfate in Both Homogeneous and Heterogeneous Ways: A Review. Chem. Eng. J. 2020, 384, 123265. [CrossRef]

46. Duan, X.; Yang, S.; Wacławek, S.; Fang, G.; Xiao, R.; Dionysiou, D.D. Limitations and Prospects of Sulfate-Radical Based Advanced Oxidation Processes. J. Environ. Chem. Eng. 2020, 8, 103849. [CrossRef]

47. Xia, X.; Zhu, F.; Li, J.; Yang, H.; Wei, L.; Li, Q.; Jiang, J.; Zhang, G.; Zhao, Q. A Review Study on Sulfate-Radical-Based Advanced Oxidation Processes for Domestic/Industrial Wastewater Treatment: Degradation, Efficiency, and Mechanism. Front. Chem. 2020, 8, 592056. [CrossRef]

48. Sannino, F.; Pirozzi, D.; Vitiello, G.; D’Errico, G.; Aronne, A.; Fanelli, E.; Pernice, P. Oxidative Degradation of Phenanthrene in the Absence of Light Irradiation by Hybrid $\mathrm{ZrO}_{2}$-Acetylacetonate Gel-Derived Catalyst. Appl. Catal. B Environ. 2014, 156-157, 101-107. [CrossRef]

49. Sannino, F.; Pernice, P.; Imparato, C.; Aronne, A.; D’Errico, G.; Minieri, L.; Perfetti, M.; Pirozzi, D. Hybrid TiO 2 -Acetylacetonate Amorphous Gel-Derived Material with Stably Adsorbed Superoxide Radical Active in Oxidative Degradation of Organic Pollutants. RSC Adv. 2015, 5, 93831-93839. [CrossRef]

50. Pirozzi, D.; Imparato, C.; D’Errico, G.; Vitiello, G.; Aronne, A.; Sannino, F. Three-Year Lifetime and Regeneration of Superoxide Radicals on the Surface of Hybrid $\mathrm{TiO}_{2}$ Materials Exposed to Air. J. Hazard. Mater. 2020, 387, 121716. [CrossRef]

51. Imparato, C.; Passaro, J.; Bifulco, A.; Branda, F.; Pirozzi, D.; Aronne, A. Development of Hybrid Titanium Oxide-Based Systems for the Surface Stabilization of Reactive Oxygen Radicals. Chem. Eng. Trans. 2021, 84, 139-144. [CrossRef]

52. Ritacco, I.; Imparato, C.; Falivene, L.; Cavallo, L.; Magistrato, A.; Caporaso, L.; Farnesi Camellone, M.; Aronne, A. Spontaneous Production of Ultrastable Reactive Oxygen Species on Titanium Oxide Surfaces Modified with Organic Ligands. Adv. Mater. Interfaces 2021, 8, 2100629. [CrossRef]

53. Liang, Z.; Yan, C.F.; Rtimi, S.; Bandara, J. Piezoelectric Materials for Catalytic/Photocatalytic Removal of Pollutants: Recent Advances and Outlook. Appl. Catal. B Environ. 2019, 241, 256-269. [CrossRef]

54. Nie, G.; Yao, Y.; Duan, X.; Xiao, L.; Wang, S. Advances of Piezoelectric Nanomaterials for Applications in Advanced Oxidation Technologies. Curr. Opin. Chem. Eng. 2021, 33, 100693. [CrossRef]

55. Russo, M.; Iervolino, G.; Vaiano, V.; Palma, V. Non-Thermal Plasma Coupled with Catalyst for the Degradation of Water Pollutants: A Review. Catalysts 2020, 10, 1438. [CrossRef]

56. Nam, S.-N.; Choong, C.E.; Hoque, S.; Farouk, T.I.; Cho, J.; Jang, M.; Snyder, S.A.; Meadows, M.E.; Yoon, Y. Catalytic Non-Thermal Plasma Treatment of Endocrine Disrupting Compounds, Pharmaceuticals, and Personal Care Products in Aqueous Solution: A Review. Chemosphere 2022, 290, 133395. [CrossRef] [PubMed]

57. Staples, C.A.; Dorn, P.B.; Klecka, G.M.; O'Block, S.T.; Harris, L.R. A Review of the Environmental Fate, Effects, and Exposures of Bisphenol A. Chemosphere 1998, 36, 2149-2173. [CrossRef]

58. Ismail, N.A.H.; Wee, S.Y.; Aris, A.Z. Multi-Class of Endocrine Disrupting Compounds in Aquaculture Ecosystems and Health Impacts in Exposed Biota. Chemosphere 2017, 188, 375-388. [CrossRef] [PubMed]

59. Bhatnagar, A.; Anastopoulos, I. Adsorptive Removal of Bisphenol A (BPA) from Aqueous Solution: A Review. Chemosphere 2017, 168, 885-902. [CrossRef] [PubMed]

60. Careghini, A.; Mastorgio, A.F.; Saponaro, S.; Sezenna, E. Bisphenol A, Nonylphenols, Benzophenones, and Benzotriazoles in Soils, Groundwater, Surface Water, Sediments, and Food: A Review. Environ. Sci. Pollut. Res. 2015, 22, 5711-5741. [CrossRef]

61. Rastkari, N.; Jeddi, M.Z.; Yunesian, M.; Ahmadkhaniha, R. Effect of Sunlight Exposure on Phthalates Migration from Plastic Containers to Packaged Juices. J. Environ. Health Sci. Eng. 2018, 16, 27-33. [CrossRef]

62. Russo, G.; Laneri, S.; di Lorenzo, R.; Ferrara, L.; Grumetto, L. The Occurrence of Selected Endocrine-Disrupting Chemicals in Water and Sediments from an Urban Lagoon in Southern Italy. Water Environ. Res. 2021, 93, 1944-1958. [CrossRef]

63. Jiang, J.; Mu, D.; Ding, M.; Zhang, S.; Zhang, H.; Hu, J. Simultaneous Determination of Primary and Secondary Phthalate Monoesters in the Taihu Lake: Exploration of Sources. Chemosphere 2018, 202, 17-24. [CrossRef]

64. Salaudeen, T.; Okoh, O.; Agunbiade, F.; Okoh, A. Phthalates Removal Efficiency in Different Wastewater Treatment Technology in the Eastern Cape, South Africa. Environ. Monit. Assess. 2018, 190, 299. [CrossRef]

65. Wang, Y.; Qian, H. Phthalates and Their Impacts on Human Health. Healthcare 2021, 9, 603. [CrossRef] [PubMed] 
66. Xu, L.; Yang, L.; Johansson, E.M.J.; Wang, Y.; Jin, P. Photocatalytic Activity and Mechanism of Bisphenol a Removal over $\mathrm{TiO}_{2-x} /$ RGO Nanocomposite Driven by Visible Light. Chem. Eng. J. 2018, 350, 1043-1055. [CrossRef]

67. Wang, G.; Dai, J.; Luo, Q.; Deng, N. Photocatalytic Degradation of Bisphenol A by $\mathrm{TiO}_{2} @$ aspartic Acid- $\beta$-Cyclodextrin@reduced Graphene Oxide. Sep. Purif. Technol. 2021, 254, 117574. [CrossRef]

68. Wang, H.; Zhang, N.; Cheng, G.; Guo, H.; Shen, Z.; Yang, L.; Zhao, Y.; Alsaedi, A.; Hayat, T.; Wang, X. Preparing a Photocatalytic Fe Doped $\mathrm{TiO}_{2} /$ RGO for Enhanced Bisphenol A and Its Analogues Degradation in Water Sample. Appl. Surf. Sci. 2020, 505, 144640. [CrossRef]

69. Garg, A.; Singhania, T.; Singh, A.; Sharma, S.; Rani, S.; Neogy, A.; Yadav, S.R.; Sangal, V.K.; Garg, N. Photocatalytic Degradation of Bisphenol-A Using N,Co Codoped $\mathrm{TiO}_{2}$ Catalyst under Solar Light. Sci. Rep. 2019, 9, 765. [CrossRef]

70. Zhao, X.; Wang, R.; Lu, Z.; Wang, W.; Yan, Y. Dual Sensitization Effect and Conductive Structure of $\mathrm{Fe}_{3} \mathrm{O}_{4} @ \mathrm{mTiO}_{2} / \mathrm{C} \mathrm{Photocatalyst}$ towards Superior Photodegradation Activity for Bisphenol A under Visible Light. J. Photochem. Photobiol. A Chem. 2019, 382, 111902. [CrossRef]

71. He, J.; Zeng, X.; Lan, S.; Lo, I.M.C. Reusable Magnetic Ag/Fe, N-TiO $2 / \mathrm{Fe}_{3} \mathrm{O}_{4} @ \mathrm{SiO}_{2}$ Composite for Simultaneous Photocatalytic Disinfection of E. Coli and Degradation of Bisphenol A in Sewage under Visible Light. Chemosphere 2019, 217, 869-878. [CrossRef]

72. Ju, L.; Wu, P.; Yang, Q.; Ahmed, Z.; Zhu, N. Synthesis of ZnAlTi-LDO Supported C60@AgCl Nanoparticles and Their Photocatalytic Activity for Photo-Degradation of Bisphenol A. Appl. Catal. B Environ. 2018, 224, 159-174. [CrossRef]

73. Kumar, A.; Schuerings, C.; Kumar, S.; Kumar, A.; Krishnan, V. Perovskite-Structured $\mathrm{CaTiO}_{3} \mathrm{Coupled}_{\text {with g-C }} \mathrm{N}_{4}$ as a Heterojunction Photocatalyst for Organic Pollutant Degradation. Beilstein J. Nanotechnol. 2018, 9, 671-685. [CrossRef]

74. Ma, Y.; Xu, Y.; Ji, X.; Xie, M.; Jiang, D.; Yan, J.; Song, Z.; Xu, H.; Li, H. Construction of Polythiophene/Bi ${ }_{4} \mathrm{O}_{5} \mathrm{I}_{2} \mathrm{Nanocomposites} \mathrm{to}$ Promote Photocatalytic Degradation of Bisphenol a. J. Alloys Compd. 2020, 823, 153773. [CrossRef]

75. Wu, R.; Song, H.; Luo, N.; Sheng, Y.; Ji, G. Microwave-Assisted Preparation and Enhanced Photocatalytic Activity of Bi 2 WO $6 / B B_{O I}$ Heterojunction for Organic Pollutants Degradation under Visible-Light Irradiation. Solid State Sci. 2019, 87, 101-109. [CrossRef]

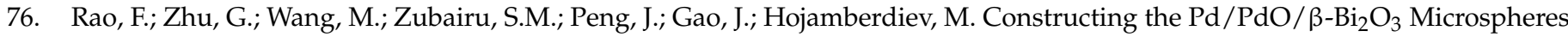
with Enhanced Photocatalytic Activity for Bisphenol A Degradation and NO Removal. J. Chem. Technol. Biotechnol. 2020, 95, 862-874. [CrossRef]

77. Li, N.; Zhu, G.; Hojamberdiev, M.; Zhu, R.; Chang, J.; Gao, J.; Guo, Q.; Liu, P. Pd Nanoparticle-Decorated Bi $\mathrm{O}_{5} \mathrm{Br}_{2} \mathrm{Nanosheets}$ with Enhanced Visible-Light Photocatalytic Activity for Degradation of Bisphenol A. J. Photochem. Photobiol. A Chem. 2018, 356, 440-450. [CrossRef]

78. Xu, Y.; Zhang, X.; Zhang, Y.; Zhu, J.; Zhu, R. Nano Flake $\mathrm{Ag}_{3} \mathrm{PO}_{4}$ Enhanced Photocatalytic Activity of Bisphenol A under Visible Light Irradiation. Colloids Interface Sci. Commun. 2020, 37, 100277. [CrossRef]

79. Karuppaiah, S.; Annamalai, R.; Muthuraj, A.; Kesavan, S.; Palani, R.; Ponnusamy, S.; Nagarajan, E.R.; Meenakshisundaram, S. Efficient Photocatalytic Degradation of Ciprofloxacin and Bisphenol A under Visible Light Using $\mathrm{Gd}_{2} \mathrm{WO}_{6}$ Loaded ZnO/Bentonite Nanocomposite. Appl. Surf. Sci. 2019, 481, 1109-1119. [CrossRef]

80. Fu, H.; Ma, S.; Zhao, P.; Xu, S.; Zhan, S. Activation of Peroxymonosulfate by Graphitized Hierarchical Porous Biochar and $\mathrm{MnFe}_{2} \mathrm{O}_{4}$ Magnetic Nanoarchitecture for Organic Pollutants Degradation: Structure Dependence and Mechanism. Chem. Eng. J. 2019, 360, 157-170. [CrossRef]

81. Kong, L.; Fang, G.; Kong, Y.; Xie, M.; Natarajan, V.; Zhou, D.; Zhan, J. Cu 2 O@B-Cyclodextrin as a Synergistic Catalyst for Hydroxyl Radical Generation and Molecular Recognitive Destruction of Aromatic Pollutants at Neutral PH. J. Hazard. Mater. 2018, 357, 109-118. [CrossRef]

82. Zhang, C.; Li, N.; Chen, D.; Xu, Q.; Li, H.; He, J.; Lu, J. The Ultrasonic-Induced-Piezoelectric Enhanced Photocatalytic Performance of ZnO/CdS Nanofibers for Degradation of Bisphenol A. J. Alloys Compd. 2021, 885, 160987. [CrossRef]

83. Zhou, Q.; Shi, Q.; Li, N.; Chen, D.; Xu, Q.; Li, H.; He, J.; Lu, J. Environmental Science Nano Rh-Doped SrTiO 3 Inverse Opal with Piezoelectric Effect for Enhanced Visible-Light-Driven Photodegradation of Bisphenol A. Environ. Sci. Nano 2020, 7, 2267. [CrossRef]

84. Huang, R.; Wu, J.; Lin, E.; Kang, Z.; Qin, N.; Bao, D. A New Strategy for Large-Scale Synthesis of $\mathrm{Na}_{0.5} \mathrm{Bi}_{0.5} \mathrm{TiO}_{3} \mathrm{Nanowires}$ and Their Application in Piezocatalytic Degradation. Nanoscale Adv. 2021, 3, 3159-3166. [CrossRef]

85. Jing, W.W.; Li, D.Q.; Li, J.; Li, X.F.; Wu, Z.H.; Liu, Y.L. Photodegradation of Dimethyl Phthalate (DMP) by UV-TiO 2 in Aqueous Solution: Operational Parameters and Kinetic Analysis. Int. J. Environ. Sci. Technol. 2018, 15, 969-976. [CrossRef]

86. Wang, C.; Zeng, T.; Gu, C.; Zhu, S.; Zhang, Q.; Luo, X. Photodegradation Pathways of Typical Phthalic Acid Esters Under UV, $\mathrm{UV} / \mathrm{TiO}_{2}$, and UV-Vis $/ \mathrm{Bi}_{2} \mathrm{WO}_{6}$ Systems. Front. Chem. 2019, 7, 852. [CrossRef] [PubMed]

87. You, S.; Hu, Y.; Liu, X.; Wei, C. Synergetic Removal of $\mathrm{Pb}(\mathrm{II})$ and Dibutyl Phthalate Mixed Pollutants on $\mathrm{Bi}_{2} \mathrm{O}_{3}-\mathrm{TiO}_{2} \mathrm{Composite}$ Photocatalyst under Visible Light. Appl. Catal. B Environ. 2018, 232, 288-298. [CrossRef]

88. Meenakshi, G.; Sivasamy, A. Nanorod ZnO/SiC Nanocomposite: An Efficient Catalyst for the Degradation of an Endocrine Disruptor under UV and Visible Light Irradiations. J. Environ. Chem. Eng. 2018, 6, 3757-3769. [CrossRef]

89. Li, S.; Lai, C.; Li, C.; Zhong, J.; He, Z.; Peng, Q.; Liu, X.; Ke, B. Enhanced Photocatalytic Degradation of Dimethyl Phthalate by Magnetic Dual Z-Scheme Iron Oxide/Mpg- $\mathrm{C}_{3} \mathrm{~N}_{4} / \mathrm{BiOBr} /$ Polythiophene Heterostructure Photocatalyst under Visible Light. J. Mol. Liq. 2021, 342, 116947. [CrossRef]

90. di Dong, C.; Huang, C.P.; Nguyen, T.B.; Hsiung, C.F.; Wu, C.H.; Lin, Y.L.; Chen, C.W.; Hung, C.M. The Degradation of Phthalate Esters in Marine Sediments by Persulfate over Iron-Cerium Oxide Catalyst. Sci. Total Environ. 2019, 696, 133973. [CrossRef] 
91. Ding, S.; Wan, J.; Ma, Y.; Wang, Y.; Li, X.; Sun, J.; Pu, M. Targeted Degradation of Dimethyl Phthalate by Activating Persulfate Using Molecularly Imprinted Fe-MOF-74. Chemosphere 2021, 270, 128620. [CrossRef]

92. FAO. Available online: https://www.fao.org/faostat/ (accessed on 31 January 2022).

93. Rostami, S.; Jafari, S.; Moeini, Z.; Jaskulak, M.; Keshtgar, L.; Badeenezhad, A.; Azhdarpoor, A.; Rostami, M.; Zorena, K.; Dehghani, M. Current Methods and Technologies for Degradation of Atrazine in Contaminated Soil and Water: A Review. Environ. Technol. Innov. 2021, 24, 102019. [CrossRef]

94. Khavar, A.H.C.; Moussavi, G.; Mahjoub, A.R.; Satari, M.; Abdolmaleki, P. Synthesis and Visible-Light Photocatalytic Activity

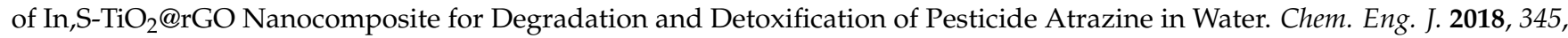
300-311. [CrossRef]

95. Shawky, A.; Mohamed, R.M.; Mkhalid, I.A.; Youssef, M.A.; Awwad, N.S. Visible Light-Responsive Ag/LaTiO 3 Nanowire Photocatalysts for Efficient Elimination of Atrazine Herbicide in Water. J. Mol. Liq. 2020, 299, 112163. [CrossRef]

96. Shawky, A.; Alhaddad, M.; Mohamed, R.M.; Awwad, N.S.; Ibrahium, H.A. Magnetically Separable and Visible Light-Active $\mathrm{Ag} / \mathrm{NiCO}_{2} \mathrm{O}_{4}$ Nanorods Prepared by a Simple Route for Superior Photodegradation of Atrazine in Water. Prog. Nat. Sci. Mater. Int. 2020, 30, 160-167. [CrossRef]

97. Majhi, D.; Das, K.; Mishra, A.; Dhiman, R.; Mishra, B.G. One Pot Synthesis of CdS/BiOBr $/ \mathrm{Bi}_{2} \mathrm{O}_{2} \mathrm{CO}_{3}$ : A Novel Ternary Double Z-Scheme Heterostructure Photocatalyst for Efficient Degradation of Atrazine. Appl. Catal. B Environ. 2020, $260,118222$. [CrossRef]

98. Yang, N.; Liu, Y.; Zhu, J.; Wang, Z.; Li, J. Study on the Efficacy and Mechanism of Fe-TiO 2 Visible Heterogeneous Fenton Catalytic Degradation of Atrazine. Chemosphere 2020, 252, 126333. [CrossRef]

99. Huang, Y.; Han, C.; Liu, Y.; Nadagouda, M.N.; Machala, L.; O'Shea, K.E.; Sharma, V.K.; Dionysiou, D.D. Degradation of Atrazine by $\mathrm{Zn}_{\mathrm{x}} \mathrm{Cu}_{1-\mathrm{x}} \mathrm{Fe}_{2} \mathrm{O}_{4}$ Nanomaterial-Catalyzed Sulfite under UV-Vis Light Irradiation: Green Strategy to Generate $\mathrm{SO}_{4}{ }^{-}$. Appl. Catal. B Environ. 2018, 221, 380-392. [CrossRef]

100. Xie, S.; Tang, C.; Shi, H.; Zhao, G. Highly Efficient Photoelectrochemical Removal of Atrazine and the Mechanism Investigation: Bias Potential Effect and Reactive Species. J. Hazard. Mater. 2021, 415, 125681. [CrossRef]

101. Zhang, L.; Zhang, Y.; Xiao, K.; Shi, J.; Du, X.; Wang, L.; Wu, X. The Intimate Coupling of Photocatalysis and Biodegradation for the Degradation and Mineralization of Atrazine in Water. New J. Chem. 2021, 45, 13029-13039. [CrossRef]

102. Xu, X.; Chen, W.; Zong, S.; Ren, X.; Liu, D. Atrazine Degradation Using $\mathrm{Fe}_{3} \mathrm{O}_{4}$-Sepiolite Catalyzed Persulfate: Reactivity, Mechanism and Stability. J. Hazard. Mater. 2019, 377, 62-69. [CrossRef]

103. Li, J.; Wan, Y.; Li, Y.; Yao, G.; Lai, B. Surface Fe(III)/Fe(II) Cycle Promoted the Degradation of Atrazine by Peroxymonosulfate Activation in the Presence of Hydroxylamine. Appl. Catal. B Environ. 2019, 256, 117782. [CrossRef]

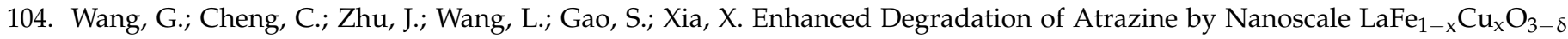
Perovskite Activated Peroxymonosulfate: Performance and Mechanism. Sci. Total Environ. 2019, 673, 565-575. [CrossRef]

105. Dong, X.; Ren, B.; Zhang, X.; Liu, X.; Sun, Z.; Li, C.; Tan, Y.; Yang, S.; Zheng, S.; Dionysiou, D.D. Diatomite Supported Hierarchical $2 \mathrm{D} \mathrm{CoNi}_{3} \mathrm{O}_{4}$ Nanoribbons as Highly Efficient Peroxymonosulfate Catalyst for Atrazine Degradation. Appl. Catal. B Environ. 2020, 272, 118971. [CrossRef]

106. Chen, S.; He, P.; Wang, X.; Xiao, F.; Zhou, P.; He, Q.; Jia, L.; Dong, F.; Zhang, H.; Jia, B.; et al. Co/Sm-Modified Ti/PbO 2 Anode for Atrazine Degradation: Effective Electrocatalytic Performance and Degradation Mechanism. Chemosphere 2021, $268,128799$. [CrossRef] [PubMed]

107. Li, J.; Yan, J.; Yao, G.; Zhang, Y.; Li, X.; Lai, B. Improving the Degradation of Atrazine in the Three-Dimensional (3D) Electrochemical Process Using $\mathrm{CuFe}_{2} \mathrm{O}_{4}$ as Both Particle Electrode and Catalyst for Persulfate Activation. Chem. Eng. J. 2019, 361, $1317-1332$. [CrossRef]

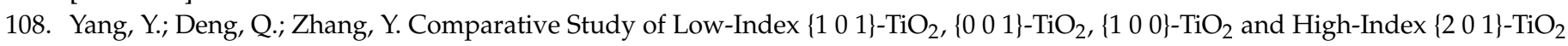
on Glyphosate Adsorption and Photo-Degradation. Chem. Eng. J. 2019, 360, 1247-1254. [CrossRef]

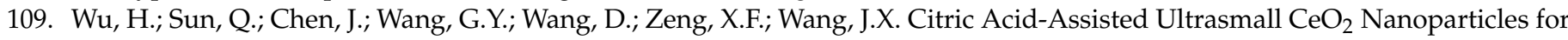
Efficient Photocatalytic Degradation of Glyphosate. Chem. Eng. J. 2021, 425, 130640. [CrossRef]

110. Russo, M.; Iervolino, G.; Vaiano, V. W-Doped ZnO Photocatalyst for the Degradation of Glyphosate in Aqueous Solution. Catalysts 2021, 11, 234. [CrossRef]

111. Cao, L.; Ma, D.; Zhou, Z.; Xu, C.; Cao, C.; Zhao, P.; Huang, Q. Efficient Photocatalytic Degradation of Herbicide Glyphosate in Water by Magnetically Separable and Recyclable $\mathrm{BiOBr} / \mathrm{Fe}_{3} \mathrm{O}_{4}$ Nanocomposites under Visible Light Irradiation. Chem. Eng. J. 2019, 368, 212-222. [CrossRef]

112. Luo, X.L.; Chen, Z.Y.; Yang, S.Y.; Xu, Y.H. Two-Step Hydrothermal Synthesis of Peanut-Shaped Molybdenum Diselenide/Bismuth Vanadate $\left(\mathrm{MoSe}_{2} / \mathrm{BiVO}_{4}\right)$ with Enhanced Visible-Light Photocatalytic Activity for the Degradation of Glyphosate. J. Colloid Interface Sci. 2018, 532, 456-463. [CrossRef]

113. Tang, Q.Y.; Chen, W.F.; Lv, Y.R.; Yang, S.Y.; Xu, Y.H. Z-Scheme Hierarchical $\mathrm{Cu}_{2} \mathrm{~S} / \mathrm{Bi}_{2} \mathrm{WO}_{6}$ Composites for Improved Photocatalytic Activity of Glyphosate Degradation under Visible Light Irradiation. Sep. Purif. Technol. 2020, 236, 116243. [CrossRef]

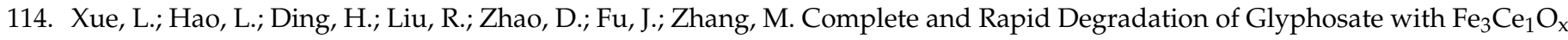
Catalyst for Peroxymonosulfate Activation at Room Temperature. Environ. Res. 2021, 201, 111618. [CrossRef]

115. Marien, C.B.D.; le Pivert, M.; Azaïs, A.; M’Bra, I.C.; Drogui, P.; Dirany, A.; Robert, D. Kinetics and Mechanism of Paraquat's Degradation: UV-C Photolysis vs UV-C Photocatalysis with $\mathrm{TiO}_{2} / \mathrm{SiC}$ Foams. J. Hazard. Mater. 2019, 370, 164-171. [CrossRef] 
116. Vanichvattanadecha, C.; Jaroenworaluck, A.; Henpraserttae, P.; Wimuktiwan, P.; Manpetch, P.; Singhapong, W. Ordered Mesoporous Silica (SBA-16) Supporting Titania $\left(\mathrm{TiO}_{2}\right)$ Nanoparticles for Photodegradation of Paraquat (PQ) Herbicide. J. Porous Mater. 2021, 28, 1137-1153. [CrossRef]

117. Suwannaruang, T.; Kamonsuangkasem, K.; Kidkhunthod, P.; Chirawatkul, P.; Saiyasombat, C.; Chanlek, N.; Wantala, K. Influence of Nitrogen Content Levels on Structural Properties and Photocatalytic Activities of Nanorice-like N-Doped TiO ${ }_{2}$ with Various Calcination Temperatures. Mater. Res. Bull. 2018, 105, 265-276. [CrossRef]

118. Pourzad, A.; Sobhi, H.R.; Behbahani, M.; Esrafili, A.; Kalantary, R.R.; Kermani, M. Efficient Visible Light-Induced Photocatalytic Removal of Paraquat Using N-Doped $\mathrm{TiO}_{2} @ \mathrm{SiO}_{2} @ \mathrm{Fe}_{3} \mathrm{O}_{4}$ Nanocomposite. J. Mol. Liq. 2020, 299, 112167. [CrossRef]

119. Zangeneh, H.; Zinatizadeh, A.A.; Feyzi, M.; Zinadini, S.; Bahnemann, D.W. Photomineralization of Recalcitrant Wastewaters by a Novel Magnetically Recyclable Boron Doped- $\mathrm{TiO}_{2}-\mathrm{SiO}_{2}$ Cobalt Ferrite Nanocomposite as a Visible-Driven Heterogeneous Photocatalyst. J. Environ. Chem. Eng. 2018, 6, 6370-6381. [CrossRef]

120. Khodkar, A.; Khezri, S.M.; Pendashteh, A.R.; Khoramnejadian, S.; Mamani, L. A Designed Experimental Approach for Photocatalytic Degradation of Paraquat Using $\alpha-\mathrm{Fe}_{2} \mathrm{O}_{3} @ \mathrm{MIL}-101(\mathrm{Cr}) @ \mathrm{TiO}_{2}$ Based on Metal-Organic Framework. Int. J. Environ. Sci. Technol. 2019, 16, 5741-5756. [CrossRef]

121. Kumar, A.; Kumar, A.; Sharma, G.; Al-Muhtaseb, A.H.; Naushad, M.; Ghfar, A.A.; Guo, C.; Stadler, F.J. Biochar-Templated g- $\mathrm{C}_{3} \mathrm{~N}_{4} / \mathrm{Bi}_{2} \mathrm{O}_{2} \mathrm{CO}_{3} / \mathrm{CoFe}_{2} \mathrm{O}_{4}$ Nano-Assembly for Visible and Solar Assisted Photo-Degradation of Paraquat, Nitrophenol Reduction and $\mathrm{CO}_{2}$ Conversion. Chem. Eng. J. 2018, 339, 393-410. [CrossRef]

122. Mary Nisha, U.; Umapathy, M.J.; Sivasamy, A. Effective Degradation of 2,4-Dichlorophenoxy Acetic Acid Endocrine Disruptor Using $\mathrm{CeO}_{2}-\mathrm{Bi}_{2} \mathrm{O}_{3}$ Mixed Metal Oxide Photocatalyst under Visible Light Irradiation. J. Mater. Sci. Mater. Electron. 2021, 32, 14791-14800. [CrossRef]

123. Lima, M.S.; Cruz-Filho, J.F.; Noleto, L.F.G.; Silva, L.J.; Costa, T.M.S.; Luz, G.E. Synthesis, Characterization and Catalytic Activity of $\mathrm{Fe}_{3} \mathrm{O}_{4} @ \mathrm{WO}_{3} / \mathrm{SBA}-15$ on Photodegradation of the Acid Dichlorophenoxyacetic (2,4-D) under UV Irradiation. J. Environ. Chem. Eng. 2020, 8, 104145. [CrossRef]

124. Xu, X.; Cai, J.; Zhou, M.; Du, X.; Zhang, Y. Photoelectrochemical Degradation of 2,4-Dichlorophenoxyacetic Acid Using Electrochemically Self-Doped Blue $\mathrm{TiO}_{2}$ Nanotube Arrays with Formic Acid as Electrolyte. J. Hazard. Mater. 2020, $382,121096$. [CrossRef]

125. Sharma, R.K.; Arora, B.; Sharma, S.; Dutta, S.; Sharma, A.; Yadav, S.; Solanki, K. In Situ Hydroxyl Radical Generation Using the Synergism of the Co-Ni Bimetallic Centres of a Developed Nanocatalyst with Potent Efficiency for Degrading Toxic Water Pollutants. Mater. Chem. Front. 2020, 4, 605-620. [CrossRef]

126. Riaz, U.; Zia, J. Microwave-Assisted Rapid Degradation of DDT Using Nanohybrids of PANI with $\mathrm{SnO}_{2}$ Derived from Psidium Guajava Extract. Environ. Pollut. 2020, 259, 113917. [CrossRef] [PubMed]

127. Liu, J.; An, F.; Zhu, C.; Zhou, D. Efficient Transformation of DDT with Peroxymonosulfate Activation by Different Crystallographic $\mathrm{MnO}_{2}$. Sci. Total Environ. 2021, 759, 142864. [CrossRef] [PubMed]

128. Vela, N.; Calín, M.; Yáñez-Gascón, M.J.; Garrido, I.; Pérez-Lucas, G.; Fenoll, J.; Navarro, S. Photocatalytic Oxidation of Six Pesticides Listed as Endocrine Disruptor Chemicals from Wastewater Using Two Different $\mathrm{TiO}_{2}$ Samples at Pilot Plant Scale under Sunlight Irradiation. J. Photochem. Photobiol. A Chem. 2018, 353, 271-278. [CrossRef]

129. Vela, N.; Calín, M.; Yáñez-Gascón, M.J.; el Aatik, A.; Garrido, I.; Pérez-Lucas, G.; Fenoll, J.; Navarro, S. Removal of Pesticides with Endocrine Disruptor Activity in Wastewater Effluent by Solar Heterogeneous Photocatalysis Using $\mathrm{ZnO}_{/} \mathrm{Na}_{2} \mathrm{~S}_{2} \mathrm{O}_{8}$. Water Air Soil Pollut. 2019, 230, 134. [CrossRef]

130. Rossetti, M.F.; Stoker, C.; Ramos, J.G. Agrochemicals and Neurogenesis. Mol. Cell. Endocrinol. 2020, 510, 110820. [CrossRef]

131. Kalofiri, P.; Balias, G.; Tekos, F. The EU Endocrine Disruptors' Regulation and the Glyphosate Controversy. Toxicol. Rep. 2021, 8, 1193-1199. [CrossRef]

132. Alulema-Pullupaxi, P.; Fernández, L.; Debut, A.; Santacruz, C.P.; Villacis, W.; Fierro, C.; Espinoza-Montero, P.J. Photoelectrocatalytic Degradation of Glyphosate on Titanium Dioxide Synthesized by Sol-Gel/Spin-Coating on Boron Doped Diamond $\left(\mathrm{TiO}_{2} / \mathrm{BDD}\right)$ as a Photoanode. Chemosphere 2021, 278, 130488. [CrossRef]

133. Phuinthiang, P.; Kajitvichyanukul, P. Degradation of Paraquat from Contaminated Water Using Green TiO $\mathrm{Nanoparticles}_{2}$ Synthesized from Coffea arabica L. in Photocatalytic Process. Water Sci. Technol. 2018, 79, 905-910. [CrossRef]

134. Sharma, S.; Basu, S. Highly Reusable Visible Light Active Hierarchical Porous $\mathrm{WO}_{3} / \mathrm{SiO}_{2}$ Monolith in Centimeter Length Scale for Enhanced Photocatalytic Degradation of Toxic Pollutants. Sep. Purif. Technol. 2020, 231, 115916. [CrossRef]

135. Quan, Y.; Yao, J.; Yang, S.; Chen, L.; Liu, Y.; Lang, J.; Zeng, H.; Yang, J.; Gao, M. Detect, Remove and Re-Use: Sensing and Degradation Pesticides via 3D Tilted ZMRs/Ag Arrays. J. Hazard. Mater. 2020, 391, 122222. [CrossRef]

136. Fidelis, M.Z.; Abreu, E.; Josué, T.G.; de Almeida, L.N.B.; Lenzi, G.G.; Santos, O.A.A. dos Continuous Process Applied to Degradation of Triclosan and 2.8-Dichlorodibenzene-p-Dioxin. Environ. Sci. Pollut. Res. 2021, 28, 23675-23683. [CrossRef] [PubMed]

137. Kaur, H.; Dahake, R.; Maddigapu, P.R.; Hippargi, G.; Pophali, G.R.; Bansiwal, A. Enhanced Photocatalytic Degradation of Antimicrobial Triclosan Using $\mathrm{RGO}-\mathrm{TiO}_{2}$ Composite under Natural Solar Illumination. J. Mater. Sci. Mater. Electron. 2020, 31, 6045-6058. [CrossRef]

138. Ojha, A.; Singh, P.; Tiwary, D. Photocatalytic Degradation of Triclosan in Visible-Light-Induced via CdS@TiO $2-\mathrm{RGO} \mathrm{Nanocompos}^{-}$ ite. Surf. Topogr.: Metrol. Prop. 2021, 9, 035032. [CrossRef] 
139. Chandra Pragada, S.; Thalla, A.K. Polymer-Based Immobilized $\mathrm{Fe}_{2} \mathrm{O}_{3}-\mathrm{TiO}_{2} /$ PVP Catalyst Preparation Method and the Degradation of Triclosan in Treated Greywater Effluent by Solar Photocatalysis. J. Environ. Manag. 2021, 296, 113305. [CrossRef]

140. Köwitsch, I.; Mehring, M. Coatings of Magnetic Composites of Iron Oxide and Carbon Nitride for Photocatalytic Water Purification. RSC Adv. 2021, 11, 14053-14062. [CrossRef]

141. Katal, R.; Panah, S.M.; Saeedikhani, M.; Kosari, M.; Sheng, C.C.; Leong, O.S.; Xiao, G.; Jiangyong, H. Pd-Decorated CuO Thin Film for Photodegradation of Acetaminophen and Triclosan under Visible Light Irradiation. Adv. Mater. Interfaces 2018, 5, 1801440. [CrossRef]

142. Tiwari, A.; Shukla, A.; Lalliansanga; Tiwari, D.; Lee, S.M. Synthesis and Characterization of $\mathrm{Ag}^{0}(\mathrm{NPs}) / \mathrm{TiO}_{2} \mathrm{Nanocomposite:}$ Insight Studies of Triclosan Removal from Aqueous Solutions. Environ. Technol. 2020, 41, 3500-3514. [CrossRef]

143. Ferreira, O.; Monteiro, O.C.; do Rego, A.M.B.; Ferraria, A.M.; Batista, M.; Santos, R.; Monteiro, S.; Freire, M.; Silva, E.R. Visible Light-Driven Photodegradation of Triclosan and Antimicrobial Activity against Legionella Pneumophila with Cobalt and Nitrogen Co-Doped $\mathrm{TiO}_{2}$ Anatase Nanoparticles. J. Environ. Chem. Eng. 2021, 9, 106735. [CrossRef]

144. Chen, Z.; Bi, S.; Zhao, G.; Chen, Y.; Hu, Y. Enhanced Degradation of Triclosan by Cobalt Manganese Spinel-Type Oxide Activated Peroxymonosulfate Oxidation Process via Sulfate Radicals and Singlet Oxygen: Mechanisms and Intermediates Identification. Sci. Total Environ. 2020, 711, 134715. [CrossRef]

145. So, H.L.; Lin, K.Y.; Chu, W. Triclosan Removal by Heterogeneous Fenton-like Process: Studying the Kinetics and Surface Chemistry of $\mathrm{Fe}_{3} \mathrm{O}_{4}$ as Catalyst. J. Environ. Chem. Eng. 2019, 7, 103432. [CrossRef]

146. So, H.L.; Lin, K.Y.; Chu, W.; Gong, H. Degradation of Triclosan by Recyclable $\mathrm{MnFe}_{2} \mathrm{O}_{4}$-Activated PMS: Process Modification for Reduced Toxicity and Enhanced Performance. Ind. Eng. Chem. Res. 2020, 59, 4257-4264. [CrossRef]

147. Huang, Z.; Lin, Q.; Cai, N.; Weng, Q.; Xu, J.; Gan, S.; Chen, C.; Zhong, Q.; Fu, H.; Xia, Y.; et al. Coexistence of Free Radical and Nonradical Mechanisms for Triclosan Degradation by CuO/HNTs. Sep. Purif. Technol. 2021, 276, 119318. [CrossRef]

148. Song, X.; Ren, C.; Zhao, Q.; Su, B. Simultaneous Removal of $\mathrm{Cr}(\mathrm{VI})$ and Triclosan from Aqueous Solutions through $\mathrm{Fe}_{3} \mathrm{O}_{4}$ Magnetic Nanoscale-Activated Persulfate Oxidation. Chem. Eng. J. 2020, 381, 122586. [CrossRef]

149. Ajiboye, T.O.; Oyewo, O.A.; Onwudiwe, D.C. Photocatalytic Removal of Parabens and Halogenated Products in Wastewater: A Review. Environ. Chem. Lett. 2021, 19, 3789-3819. [CrossRef]

150. de Jesus, R.A.; de Assis, G.C.; de Oliveira, R.J.; Costa, J.A.S.; da Silva, C.M.P.; Bilal, M.; Iqbal, H.M.N.; Ferreira, L.F.R.; Figueiredo, R.T. Environmental Remediation Potentialities of Metal and Metal Oxide Nanoparticles: Mechanistic Biosynthesis, Influencing Factors, and Application Standpoint. Environ. Technol. Innov. 2021, 24, 101851. [CrossRef]

151. Ngigi, E.M.; Nomngongo, P.N.; Ngila, J.C. Recent Methods Used in Degradation of Parabens in Aqueous Solutions: A Review. Int. J. Environ. Sci. Technol. 2022, 19, 2139-2154. [CrossRef]

152. Foszpańczyk, M.; Bednarczyk, K.; Drozdek, E.; Martins, R.C.; Ledakowicz, S.; Gmurek, M. Comparison of Photocatalytic and Photosensitized Oxidation of Paraben Aqueous Solutions Under Sunlight. Water Air Soil Pollut. 2018, 229, 362. [CrossRef]

153. Gomes, J.; Lincho, J.; Domingues, E.; Gmurek, M.; Mazierski, P.; Zaleska-Medynska, A.; Klimczuk, T.; Quinta-Ferreira, R.M.; Martins, R.C. $\mathrm{TiO}_{2}$ Nanotube Arrays-Based Reactor for Photocatalytic Oxidation of Parabens Mixtures in Ultrapure Water: Effects of Photocatalyst Properties, Operational Parameters and Light Source. Sci. Total Environ. 2019, 689, 79-89. [CrossRef]

154. Lincho, J.; Gomes, J.; Kobylanski, M.; Bajorowicz, B.; Zaleska-Medynska, A.; Martins, R.C. TiO 2 Nanotube Catalysts for Parabens Mixture Degradation by Photocatalysis and Ozone-Based Technologies. Process Saf. Environ. Prot. 2021, 152, 601-613. [CrossRef]

155. Vela, N.; Calín, M.; Yáñez-Gascón, M.J.; Garrido, I.; Pérez-Lucas, G.; Fenoll, J.; Navarro, S. Solar Reclamation of Wastewater Effluent Polluted with Bisphenols, Phthalates and Parabens by Photocatalytic Treatment with $\mathrm{TiO}_{2} / \mathrm{Na}_{2} \mathrm{~S}_{2} \mathrm{O}_{8}$ at Pilot Plant Scale. Chemosphere 2018, 212, 95-104. [CrossRef]

156. Petala, A.; Noe, A.; Frontistis, Z.; Drivas, C.; Kennou, S.; Mantzavinos, D.; Kondarides, D.I. Synthesis and Characterization of $\mathrm{CoO}_{x} / \mathrm{BiVO}_{4}$ Photocatalysts for the Degradation of Propyl Paraben. J. Hazard. Mater. 2019, 372, 52-60. [CrossRef] [PubMed]

157. Moschogiannaki, M.; Frontistis, Z.; Kiriakidis, G.; Mantzavinos, D.; Binas, V. Porous $\mathrm{Co}_{x} \mathrm{Ni}_{1-\mathrm{x}} \mathrm{TiO}_{3}$ Nanorods for Solar Photocatalytic Degradation of Ethyl Paraben. J. Mater. 2020, 6, 788-799. [CrossRef]

158. Sheikhmohammadi, A.; Nourmoradi, H.; Manshouri, M.; Asgari, E. Performance Intensification of BzP Photo-Catalytic Degradation through Adding Exogenous Oxidant. Optik 2020, 202, 163571. [CrossRef]

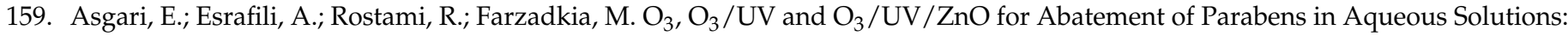
Effect of Operational Parameters and Mineralization/Biodegradability Improvement. Process Saf. Environ. Prot. 2019, 125, 238-250. [CrossRef]

160. Pratush, A.; Ye, X.; Yang, Q.; Kan, J.; Peng, T.; Wang, H.; Huang, T.; Xiong, G.; Hu, Z. Biotransformation Strategies for Steroid Estrogen and Androgen Pollution. Appl. Microbiol. Biotechnol. 2020, 104, 2385-2409. [CrossRef]

161. Du, P.; Chang, J.; Zhao, H.; Liu, W.; Dang, C.; Tong, M.; Ni, J.; Zhang, B. Sea-Buckthorn-Like MnO $_{2}$ Decorated Titanate Nanotubes with Oxidation Property and Photocatalytic Activity for Enhanced Degradation of $17 \beta$-Estradiol under Solar Light. ACS Appl. Energy Mater. 2018, 1, 2123-2133. [CrossRef]

162. Sun, K.; Liu, Q.; Li, S.; Qi, Y.; Si, Y. $\mathrm{MnO}_{2}$ Nanozyme-Driven Polymerization and Decomposition Mechanisms of $17 \beta$-Estradiol: Influence of Humic Acid. J. Hazard. Mater. 2020, 393, 122393. [CrossRef]

163. Kovacic, M.; Kopcic, N.; Kusic, H.; Bozic, A.L. Solar Driven Degradation of 17ß-Estradiol Using Composite Photocatalytic Materials and Artificial Irradiation Source: Influence of Process and Water Matrix Parameters. J. Photochem. Photobiol. A Chem. 2018, 361, 48-61. [CrossRef] 
164. Majumder, A.; Gupta, A.K. Enhanced Photocatalytic Degradation of $17 \beta$-Estradiol by Polythiophene Modified Al-Doped ZnO: Optimization of Synthesis Parameters Using Multivariate Optimization Techniques. J. Environ. Chem. Eng. 2020, 8, 104463. [CrossRef]

165. Wei, X.; Li, J.; Liu, Z.; Yang, X.; Naraginti, S.; Xu, X.; Wang, X. Visible Light Photocatalytic Mineralization of $17 \alpha$-Ethinyl

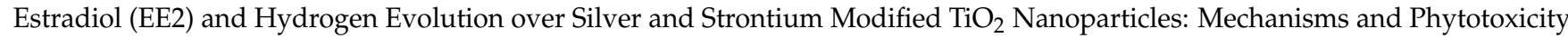
Assessment. RSC Adv. 2018, 8, 4329-4339. [CrossRef]

166. Menon, N.G.; George, L.; Tatiparti, S.S.V.; Mukherji, S. Efficacy and Reusability of Mixed-Phase $\mathrm{TiO}_{2}-\mathrm{ZnO} \mathrm{Nanocomposites} \mathrm{for}$ the Removal of Estrogenic Effects of $17 \beta$-Estradiol and $17 \alpha$-Ethinylestradiol from Water. J. Environ. Manag. 2021, $288,112340$. [CrossRef] [PubMed]

167. Abreu, E.; Fidelis, M.Z.; Fuziki, M.E.; Malikoski, R.M.; Mastsubara, M.C.; Imada, R.E.; Diaz de Tuesta, J.L.; Gomes, H.T.; Anziliero, M.D.; Baldykowski, B.; et al. Degradation of Emerging Contaminants: Effect of Thermal Treatment on nb $\mathrm{O}_{5}$ as Photocatalyst. J. Photochem. Photobiol. A Chem. 2021, 419, 113484. [CrossRef]

168. Villa, K.; Parmar, J.; Vilela, D.; Sánchez, S. Core-Shell Microspheres for the Ultrafast Degradation of Estrogen Hormone at Neutral pH. RSC Adv. 2018, 8, 5840-5847. [CrossRef]

169. Zhu, N.; Li, C.; Bu, L.; Tang, C.; Wang, S.; Duan, P.; Yao, L.; Tang, J.; Dionysiou, D.D.; Wu, Y. Bismuth Impregnated Biochar for Efficient Estrone Degradation: The Synergistic Effect between Biochar and $\mathrm{Bi} / \mathrm{Bi}_{2} \mathrm{O}_{3}$ for a High Photocatalytic Performance. J. Hazard. Mater. 2020, 384, 121258. [CrossRef] [PubMed]

170. Ramírez-Sánchez, I.M.; Bandala, E.R. Photocatalytic Degradation of Estriol Using Iron-Doped TiO 2 under High and Low UV Irradiation. Catalysts 2018, 8, 625. [CrossRef]

171. Escudeiro de Oliveira, M.; Barroso, B.L.; de Almeida, J.; Moraes, M.L.L.; de Arruda Rodrigues, C. Photoelectrocatalytic Degradation of $17 \alpha$-Ethinylestradiol and Estrone under UV and Visible Light Using Nanotubular Oxide Arrays Grown on Ti-0.5wt\%W. Environ. Res. 2020, 191, 110044. [CrossRef]

172. González-Rodríguez, J.; Gamallo, M.; Conde, J.J.; Vargas-Osorio, Z.; Vázquez-Vázquez, C.; Piñeiro, Y.; Rivas, J.; Feijoo, G.; Moreira, M.T. Exploiting the Potential of Supported Magnetic Nanomaterials as Fenton-like Catalysts for Environmental Applications. Nanomaterials 2021, 11, 2902. [CrossRef]

173. Bayode, A.A.; Vieira, E.M.; Moodley, R.; Akpotu, S.; de Camargo, A.S.S.; Fatta-Kassinos, D.; Unuabonah, E.I. Tuning ZnO/GO p-n Heterostructure with Carbon Interlayer Supported on Clay for Visible-Light Catalysis: Removal of Steroid Estrogens from Water. Chem. Eng. J. 2021, 420, 127668. [CrossRef]

174. Joseita dos Santos Costa, M.; dos Santos Costa, G.; Estefany Brandão Lima, A.; Eduardo da Luz Júnior, G.; Longo, E.; Santos Cavalcante, L.; da Silva Santos, R. Photocurrent Response and Progesterone Degradation by Employing $\mathrm{WO}_{3}$ Films Modified with Platinum and Silver Nanoparticles. ChemPlusChem 2018, 83, 1153-1161. [CrossRef]

175. Maniakova, G.; Kowalska, K.; Murgolo, S.; Mascolo, G.; Libralato, G.; Lofrano, G.; Sacco, O.; Guida, M.; Rizzo, L. Comparison between Heterogeneous and Homogeneous Solar Driven Advanced Oxidation Processes for Urban Wastewater Treatment: Pharmaceuticals Removal and Toxicity. Sep. Purif. Technol. 2020, 236, 116249. [CrossRef]

176. Fanourakis, S.K.; Peña-Bahamonde, J.; Bandara, P.C.; Rodrigues, D.F. Nano-Based Adsorbent and Photocatalyst Use for Pharmaceutical Contaminant Removal during Indirect Potable Water Reuse. NPJ Clean Water 2020, 3, 1. [CrossRef]

177. Salimi, M.; Behbahani, M.; Sobhi, H.R.; Gholami, M.; Jonidi Jafari, A.; Rezaei Kalantary, R.; Farzadkia, M.; Esrafili, A. A New Nano-Photocatalyst Based on $\mathrm{Pt}$ and $\mathrm{Bi}$ Co-Doped $\mathrm{TiO}_{2}$ for Efficient Visible-Light Photo Degradation of Amoxicillin. New J. Chem. 2019, 43, 1562-1568. [CrossRef]

178. Thakur, A.; Kumar, P.; Kaur, D.; Devunuri, N.; Sinha, R.K.; Devi, P. $\mathrm{TiO}_{2}$ Nanofibres Decorated with Green-Synthesized PAu/Ag@CQDs for the Efficient Photocatalytic Degradation of Organic Dyes and Pharmaceutical Drugs. RSC Adv. 2020, 10, 8941-8948. [CrossRef]

179. Song, J.; Wu, X.; Zhang, M.; Liu, C.; Yu, J.; Sun, G.; Si, Y.; Ding, B. Highly Flexible, Core-Shell Heterostructured, and Visible-LightDriven Titania-Based Nanofibrous Membranes for Antibiotic Removal and E. Coil Inactivation. Chem. Eng. J. 2020, $379,122269$. [CrossRef]

180. Islam, S.E.; Hang, D.R.; Chen, C.H.; Sharma, K.H. Facile and Cost-Efficient Synthesis of Quasi-0D/2D ZnO/MoS 2 Nanocomposites for Highly Enhanced Visible-Light-Driven Photocatalytic Degradation of Organic Pollutants and Antibiotics. Chem. Eur. J. 2018, 24, 9305-9315. [CrossRef]

181. Lwin, H.M.; Zhan, W.; Song, S.; Jia, F.; Zhou, J. Visible-Light Photocatalytic Degradation Pathway of Tetracycline Hydrochloride with Cubic Structured $\mathrm{ZnO} / \mathrm{SnO}_{2}$ Heterojunction Nanocatalyst. Chem. Phys. Lett. 2019, 736, 136806. [CrossRef]

182. Ghoreishian, S.M.; Raju, G.S.R.; Pavitra, E.; Kwak, C.H.; Han, Y.K.; Huh, Y.S. Ultrasound-Assisted Heterogeneous Degradation of Tetracycline over Flower-like $\mathrm{RGO} / \mathrm{CdWO}_{4}$ Hierarchical Structures as Robust Solar-Light-Responsive Photocatalysts: Optimization, Kinetics, and Mechanism. Appl. Surf. Sci. 2019, 489, 110-122. [CrossRef]

183. Chen, W.; Chang, L.; Ren, S.B.; He, Z.C.; Huang, G.B.; Liu, X.H. Direct Z-Scheme 1D/2D WO $\mathrm{W}_{2.72} / \mathrm{ZnIn}_{2} \mathrm{~S}_{4}$ Hybrid Photocatalysts with Highly-Efficient Visible-Light-Driven Photodegradation towards Tetracycline Hydrochloride Removal. J. Hazard. Mater. 2020, 384, 121308. [CrossRef]

184. Kandi, D.; Behera, A.; Sahoo, S.; Parida, K. CdS QDs Modified BiOI/ $\mathrm{Bi}_{2} \mathrm{MoO}_{6}$ Nanocomposite for Degradation of Quinolone and Tetracycline Types of Antibiotics towards Environmental Remediation. Sep. Purif. Technol. 2020, 253, 117523. [CrossRef] 
185. Kumar, A.; Rana, A.; Sharma, G.; Naushad, M.; Al-Muhtaseb, A.H.; Guo, C.; Iglesias-Juez, A.; Stadler, F.J. High-Performance Photocatalytic Hydrogen Production and Degradation of Levofloxacin by Wide Spectrum-Responsive $\mathrm{Ag}_{3} / \mathrm{Fe}_{3} \mathrm{O}_{4} \mathrm{Bridged}$ $\mathrm{SrTiO}_{3} / \mathrm{g}-\mathrm{C}_{3} \mathrm{~N}_{4}$ Plasmonic Nanojunctions: Joint Effect of $\mathrm{Ag}$ and $\mathrm{Fe}_{3} \mathrm{O}_{4}$. ACS Appl. Mater. Interfaces 2018, 10, 40474-40490. [CrossRef]

186. Szabó-Bárdos, E.; Cafuta, A.; Hegedûs, P.; Fónagy, O.; Kiss, G.; Babić, S.; Škorić, I.; Horváth, O. Photolytic and Photocatalytic Degradation of Nitrofurantoin and Its Photohydrolytic Products. J. Photochem. Photobiol. A Chem. 2020, 386, 112093. [CrossRef]

187. Devi, M.; Das, B.; Barbhuiya, M.H.; Bhuyan, B.; Dhar, S.S.; Vadivel, S. Fabrication of Nanostructured NiO/WO 3 with Graphitic Carbon Nitride for Visible Light Driven Photocatalytic Hydroxylation of Benzene and Metronidazole Degradation. New J. Chem. 2019, 43, 14616-14624. [CrossRef]

188. Zhu, W.; Li, Z.; He, C.; Faqian, S.; Zhou, Y. Enhanced Photodegradation of Sulfamethoxazole by a Novel $\mathrm{WO}_{3}-\mathrm{CNT}^{\mathrm{C}} \mathrm{Composite}$ under Visible Light Irradiation. J. Alloys Compd. 2018, 754, 153-162. [CrossRef]

189. Katal, R.; Davood Abadi Farahani, M.H.; Jiangyong, H. Degradation of Acetaminophen in a Photocatalytic (Batch and Continuous System) and Photoelectrocatalytic Process by Application of Faceted-TiO ${ }_{2}$. Sep. Purif. Technol. 2020, 230, 115859. [CrossRef]

190. Namshah, K.S.; Mohamed, R.M. WO3-TiO 2 Nanocomposites for Paracetamol Degradation under Visible Light. Appl. Nanosci. 2018, 8, 2021-2030. [CrossRef]

191. Ranjith Kumar, D.; Ranjith, K.S.; Haldorai, Y.; Kandasami, A.; Rajendra Kumar, R.T. Nitrogen-Implanted ZnO Nanorod Arrays for Visible Light Photocatalytic Degradation of a Pharmaceutical Drug Acetaminophen. ACS Omega 2019, 4, 11973-11979. [CrossRef]

192. Palas, B.; Ersöz, G.; Atalay, S. Bioinspired Metal Oxide Particles as Efficient Wet Air Oxidation and Photocatalytic Oxidation Catalysts for the Degradation of Acetaminophen in Aqueous Phase. Ecotoxicol. Environ. Saf. 2019, 182, 109367. [CrossRef]

193. Sacco, O.; Murcia, J.J.; Lara, A.E.; Hernández-Laverde, M.; Rojas, H.; Navío, J.A.; Hidalgo, M.C.; Vaiano, V. Pt-TiO $2-\mathrm{Nb}_{2} \mathrm{O}_{5}$ Heterojunction as Effective Photocatalyst for the Degradation of Diclofenac and Ketoprofen. Mater. Sci. Semicond. Process. 2020, 107, 104839. [CrossRef]

194. Vitiello, G.; Iervolino, G.; Imparato, C.; Rea, I.; Borbone, F.; de Stefano, L.; Aronne, A.; Vaiano, V. F-Doped ZnO Nano- and Meso-Crystals with Enhanced Photocatalytic Activity in Diclofenac Degradation. Sci. Total Environ. 2021, 762, 143066. [CrossRef]

195. Yilmaz, E.; Salem, S.; Sarp, G.; Aydin, S.; Sahin, K.; Korkmaz, I.; Yuvali, D. $\mathrm{TiO}_{2}$ Nanoparticles and C-Nanofibers Modified Magnetic $\mathrm{Fe}_{3} \mathrm{O}_{4}$ Nanospheres $\left(\mathrm{TiO}_{2} @ \mathrm{Fe}_{3} \mathrm{O}_{4} @ \mathrm{C}-\mathrm{NF}\right)$ : A Multifunctional Hybrid Material for Magnetic Solid-Phase Extraction of Ibuprofen and Photocatalytic Degradation of Drug Molecules and Azo Dye. Talanta 2020, 213, 120813. [CrossRef]

196. Khammar, S.; Bahramifar, N.; Younesi, H. Preparation and Surface Engineering of CM- $\beta-\mathrm{CD}$ Functionalized $\mathrm{Fe}_{3} \mathrm{O}_{4} @ \mathrm{TiO}_{2}$ Nanoparticles for Photocatalytic Degradation of Polychlorinated Biphenyls (PCBs) from Transformer Oil. J. Hazard. Mater. 2020, 394, 122422. [CrossRef] [PubMed]

197. Gorbunova, T.I.; Kozhevnikova, N.S.; Vorokh, A.S.; Enyashin, A.N.; Pervova, M.G.; Zapevalov, A.Y.; Saloutin, V.I.; Chupakhin, O.N. Photolysis of Polychlorobiphenyls in the Presence of Nanocrystalline $\mathrm{TiO}_{2}$ and $\mathrm{CdS} / \mathrm{TiO}_{2}$. React. Kinet. Mech. Catal. 2019, 126, 1115-1134. [CrossRef]

198. Zhang, Y.; Nie, J.; Yuan, C.; Long, Y.; Chen, M.; Tao, J.; Wang, Q.; Cong, Y. CuO@Cu/Ag/MWNTs/Sponge Electrode-Enhanced Pollutant Removal in Dielectric Barrier Discharge (DBD) Reactor. Chemosphere 2019, 229, 273-283. [CrossRef] [PubMed]

199. Entezari, M.; Godini, H.; Sheikhmohammadi, A.; Esrafili, A. Enhanced Degradation of Polychlorinated Biphenyls with Simultaneous Usage of Reductive and Oxidative Agents over UV/Sulfite/ $\mathrm{TiO}_{2}$ Process as a New Approach of Advanced Oxidation/Reduction Processes. J. Water Process Eng. 2019, 32, 100983. [CrossRef]

200. Lei, M.; Wang, N.; Guo, S.; Zhu, L.; Ding, Y.; Tang, H. A One-Pot Consecutive Photocatalytic Reduction and Oxidation System for Complete Debromination of Tetrabromodiphenyl Ether. Chem. Eng. J. 2018, 345, 586-593. [CrossRef]

201. Lei, M.; Wang, Z.; Tang, Y.; Wang, H.; Zhu, L.; Tang, H. Peculiar and Full Debromination of Tetrabromodiphenyl Ether on $\mathrm{Pd} / \mathrm{TiO}_{2}$ : A Competing Route through Hydro-Debromination and Coupling-Debromination. Appl. Catal. B Environ. 2020, 275, 119093. [CrossRef]

202. Chen, K.; Wang, X.; Xia, P.; Xie, J.; Wang, J.; Li, X.; Tang, Y.; Li, L. Efficient Removal of 2,2' ,4,4'-Tetrabromodiphenyl Ether with a Z-Scheme $\mathrm{Cu}_{2} \mathrm{O}-\left(\mathrm{RGO}_{-} \mathrm{TiO}_{2}\right)$ Photocatalyst under Sunlight Irradiation. Chemosphere 2020, 254, 126806. [CrossRef]

203. Zhang, Y.; Dong, S.; Wang, H.; Tao, S.; Kiyama, R. Biological Impact of Environmental Polycyclic Aromatic Hydrocarbons (EPAHs) as Endocrine Disruptors. Environ. Pollut. 2016, 213, 809-824. [CrossRef]

204. Nguyen, V.-H.; Phan Thi, L.-A.; van Le, Q.; Singh, P.; Raizada, P.; Kajitvichyanukul, P. Tailored Photocatalysts and Revealed Reaction Pathways for Photodegradation of Polycyclic Aromatic Hydrocarbons (PAHs) in Water, Soil and Other Sources. Chemosphere 2020, 260, 127529. [CrossRef]

205. Martínez-Vargas, B.L.; Cruz-Ramírez, M.; Díaz-Real, J.A.; Rodríguez-López, J.L.; Bacame-Valenzuela, F.J.; Ortega-Borges, R.; Reyes-Vidal, Y.; Ortiz-Frade, L. Synthesis and Characterization of N-ZnO/p-MnO Nanocomposites for the Photocatalytic Degradation of Anthracene. J. Photochem. Photobiol. A Chem. 2019, 369, 85-96. [CrossRef]

206. Mukwevho, N.; Gusain, R.; Fosso-Kankeu, E.; Kumar, N.; Waanders, F.; Ray, S.S. Removal of Naphthalene from Simulated Wastewater through Adsorption-Photodegradation by ZnO/Ag/GO Nanocomposite. J. Ind. Eng. Chem. 2020, 81, 393-404. [CrossRef]

207. Rachna; Rani, M.; Shanker, U. Sunlight Mediated Improved Photocatalytic Degradation of Carcinogenic Benz[a]Anthracene and Benzo[a]Pyrene by Zinc Oxide Encapsulated Hexacyanoferrate Nanocomposite. J. Photochem. Photobiol. A Chem. 2019, 381, 111861. [CrossRef] 
208. Rachna; Rani, M.; Shanker, U. Enhanced Photocatalytic Degradation of Chrysene by $\mathrm{Fe}_{2} \mathrm{O}_{3} @ Z$ ZnHCF Nanocubes. Chem. Eng. J. 2018, 348, 754-764. [CrossRef]

209. Dong, C.-D.; Chen, C.-W.; Kao, C.-M.; Chien, C.-C.; Hung, C.-M. Wood-Biochar-Supported Magnetite Nanoparticles for Remediation of PAH-Contaminated Estuary Sediment. Catalysts 2018, 8, 73. [CrossRef]

210. Qin, Z.; Zhao, Z.; Jiao, W.; Han, Z.; Xia, L.; Fang, Y.; Wang, S.; Ji, L.; Jiang, Y. Coupled Photocatalytic-Bacterial Degradation of Pyrene: Removal Enhancement and Bacterial Community Responses. Environ. Res. 2020, 183, 109135. [CrossRef]

211. Cai, H.; Sun, L.; Wang, Y.; Song, T.; Bao, M.; Yang, X. Unprecedented Efficient Degradation of Phenanthrene in Water by Intimately Coupling Novel Ternary Composite $\mathrm{Mn}_{3} \mathrm{O}_{4} / \mathrm{MnO}_{2}-\mathrm{Ag}_{3} \mathrm{PO}_{4}$ and Functional Bacteria under Visible Light Irradiation. Chem. Eng. J. 2019, 369, 1078-1092. [CrossRef]

212. Guan, S.H.; Zhao, K.F.; Tong, Q.; Rao, Q.X.; Cheng, L.; Song, W.; Zhang, Q.C.; Wang, X.L.; Song, W.G. A Review of Photocatalytic Materials Application on Nonylphenol Degradation. Environ. Chall. 2021, 4, 100172. [CrossRef]

213. Tang, C.; Huang, X.; Wang, H.; Shi, H.; Zhao, G. Mechanism Investigation on the Enhanced Photocatalytic Oxidation of Nonylphenol on Hydrophobic $\mathrm{TiO}_{2}$ Nanotubes. J. Hazard. Mater. 2020, 382, 121017. [CrossRef]

214. Niu, B.; Cai, J.; Song, W.; Zhao, G. Novel Electrochemical Pretreatment for Preferential Removal of Nonylphenol in Industrial Wastewater: Biodegradability Improvement and Toxicity Reduction. Environ. Sci. Technol. 2020, 54, 1258-1266. [CrossRef]

215. Dong, C.-D.; Chen, C.-W.; Tsai, M.-L.; Chang, J.-H.; Lyu, S.-Y.; Hung, C.-M. Degradation of 4-Nonylphenol in Marine Sediments by Persulfate over Magnetically Modified Biochars. Bioresour. Technol. 2019, 281, 143-148. [CrossRef]

216. Xu, P.; Chen, M.; Lai, C.; Zeng, G.; Huang, D.; Wang, H.; Gong, X.; Qin, L.; Liu, Y.; Mo, D.; et al. Effects of Typical Engineered Nanomaterials on 4-Nonylphenol Degradation in River Sediment: Based on Bacterial Community and Function Analysis. Environ. Sci. Nano 2019, 6, 2171-2184. [CrossRef] 